Historic, Archive Document

Do not assume content reflects current scientific knowledge, policies, or practices. 

RARE AND UNUSUAL ALPINE :

PERENNIAI AND ANNUAL SEEDS.

HARDY HERBACEOUS PLANTS.

BULBS AND ROSES.

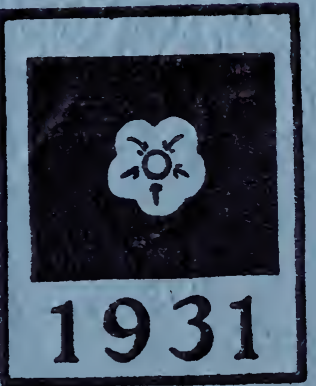





\title{
Interesting Facts About
}

\section{Huntington’s Nursery}

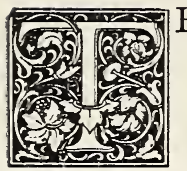

HE desire to give you the finest and newest varieties of seeds and plants at a moderate cost has formed the foundation of Huntington's reputation of being "Dependable."

We are America's pioneer in the raising and distribution of fine alpine and rare perennial seeds suitable for the climatic conditions of the United States.

A widening circle of friendships with horticultural experts, leading growers, and reputable seed collectors has enabled us to keep before our clients the really worthwhile and tried varieties of fine seeds and plants.

Every season we add to our already long list of seeds those new items that merit consideration by the garden connisseurs.

Our selection of annual seeds is governed by the same rigid tests and trials to which we subject our perennial and alpine seeds. This assures you of receiving the highest quality possible.

We are confident you will find all our seeds dependable-a fact of significant importance.

In our list of hardy herbaceous plants only those have been selected that have proven their stamina in the severe climatic conditions of the Great Lake Region. We develop the root system of all of our plants -and a plant is only as strong as its roots. Our growing program permits us to send out extra large sized, two year old plants-plants that will bloom and thrive in your garden.

We are located on the shores of Lake Erie in the center of the largest nursery district in America. Our summers are hot and dry and our winters are severely cold-the finest testing grounds for perennials in the world- "What will live and grow for us will live and grow for you."

\section{Ralph E. Huntington Nursery}

\author{
Painesville, Ohio
}




\section{Novelties and Recent}

Introductions

FEW of the finer varieties of alpine, perennial and annual seeds that 11 have recently been introduced in the horticultural world-varieties that have attracted world wide attention because of their outstanding qualities.

AQUILEGIA COMPACTA "Edelweiss" - A charming dwarf columbine with wax-like white flowers. . . . . . . . . . . . . . . . .

ARNEBIA ECHIOIDES.-A rare and handsome border plant. Bright yellow spotted with purple.

Pkt.

CALENDULA RADIO-A fine annual with quilled petals forming a golden ball.

CAMPANULA GARGANICA - Small minature alpine with bright

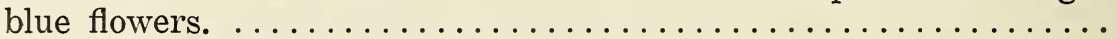

DIANTHUS, SWEET WIVELSFIELD-A new Dianthus, excellent for cutting. Brilliant colors.

DRYAS OCTOPETALA - A delightful Rocky Mountain native. Dwarf

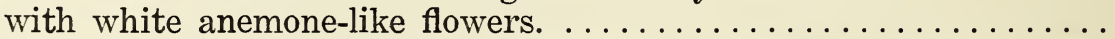

GAILLARDIA "BURGUNDY"-The first all crimson Gaillardia. Will

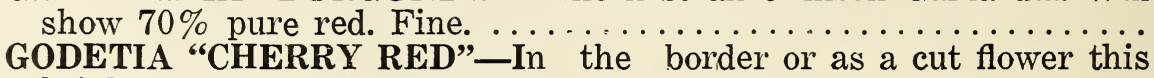
bright annual is much desired.

DAPHNE CNEORUM-A dwarf alpine shrub of high merit. Fragrant and charming. Germinates slowly.

LARKSPUR MISS CALIFORNIA-Represents the latest in larkspur culture. Rich bright pink. Double. . . . . . . . . . . . . . . . .

LILIUM MARTAGON BACKHOUSE HYBRIDS-Attractive shades

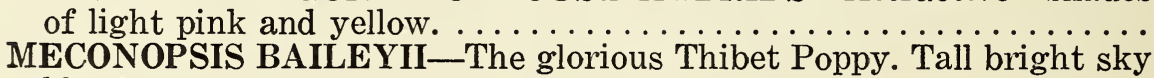
blue.

PANSY OREGON GIANTS-A marvelous strain of large flowers from

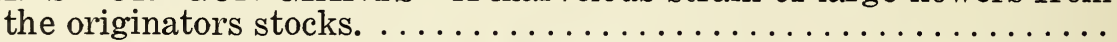

PAPAVER NUDICAULE "EL MONTE"-An extra large tangerine orange poppy from Australia. . . . . . . . . . . . . . . . . .

PENTSTEMON "SHELL PINK"-Our own origination. Clear pink

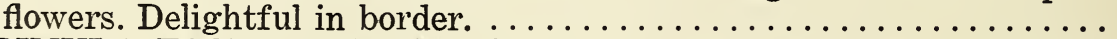

PRIMULA FLORINDAE-Multiflowered yellow pendants. A striking

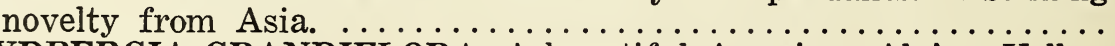

RYDBERGIA GRANDIFLORA--A beautiful American Alpine. Yellow

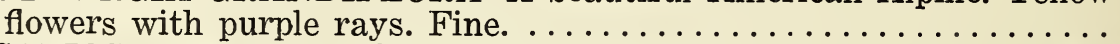

SCABIOSA SHASTA-This annual Scabiosa is pure white in large sized blossoms. Extra for cutting. ..................

SPHAERALCEA ACERIFOLIA-(Maple-Leafed Mallow) A fine new novelty from Oregon. Pink flowers.

STATICE CASPIA-Extra fine for cutting. Dwarf with much more

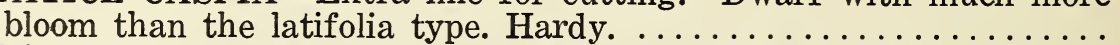

TROLLIUS LEDEBOURI "GOLDEN QUEEN"-Large, brilliant orange. Seeds germinate when sown in the Spring . . . . . . . . . . 50

VIOLA "APRICOT"-A most popular and attractive low border or rock garden plant. Superb color.

ZINNIA GIANT DAHLIA FLOWERED "GOLDEN DAWN"-Remarkable golden yellow color. Fine for cutting. .............. 


\section{Huntington's Dependable ALPINE, PERENNIAL AND BIENNIAL SEEDS}

$T_{1}$ HIS edition of our complete list of rare and choice alpine seeds and really worthwhile perennial seeds is dedicated to those people who have an interest in and a love for flowers.

Each year we make a careful selection of the newer and finer seeds not ordinarily found in the average seed catalogue. This season, besides the old established satisfactory items, we present many new interesting features which we are confident will prove "dependable."

Many of these fine varieties we grow on our own nursery, under expert supervision. Others are collected from all corners of the earth-China, Australia, Russia, Fngland, Germany, The Canadian Rockies, and from all over the United States.

Because of the widely separated localities in which these seeds are gathered it is impossible to control crop production. It will enable us to increase our service to you if you will make several additional selections to your seed order, taking care of any items which we may be short of, due to crop failure.

\section{GERMINATION}

There are many causes for the failure of perennial seeds to germinate. Weather conditions, soil conditions and other reasons vary the percent of germination. Experienced nurserymen sometimes are forced to make a second sowing. For this reason we cannot guarantee germination except under an approved test. We do guarantee fresh and clean seed.

\section{QUANTITIES}

Except in new or very scarce items, each packet will contain from 100 to 300 seeds. Trade packets will have three times the number of seeds, and in some cases will contain a thousand seeds. Many of the finer seeds are so rare that we are only able to purchase them by the thousand seeds. These we must packet accordingly.

\section{Nurserymen and growers will be interested in our quantity prices, by the ounce and pound. Please send in your planting list for quotations.}

* ROCK PLANTS

\section{ALL SEEDS ARE SENT POSTPAID}

\section{$={ }_{\text {Pkt Pkt }}^{{ }^{\mathrm{Tr}}}$}

*ACAENA-(New Zealand Burı)

Buchanani. Bluish green foliage. Trailer for rock garden ..................

Sanguisorbae. Similar to above. Bright green foliage. Good rock plant .... .15. .35

ACANTHOLIMON - ( P r i c k l y Thrift), (Bank or dry border).

Glumaceum. Rare to seed, rose color-

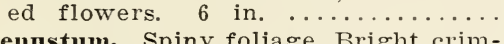

Venustum. Spiny foliage. Bright crimson flowers, very free, rare and pretty. 6 in. $\ldots \ldots \ldots \ldots \ldots \ldots \ldots \ldots \ldots$ ple flowers in spikes. Handsome ple flowers in spikes. Handsome

Lusitanicus. A good border plant with

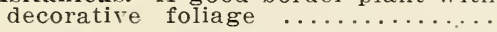

ACHILLEA - Ageratum. Medium habit. Yellow. $2 \frac{1}{2}$ feet .....................

*Clavennae. Dwarf silvery foliage.

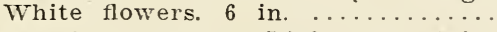

Millifolium Roseum. Light rose. Midsummer. 18 in. $1 / 4$ oz. $75 \mathrm{c} \ldots \ldots . .$.
Ptarmica The Pearl (Yarrow) Dwarf pure white double flower. 12 in. $1 / 4$

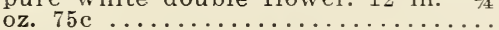

Rupestris. Neat evergreen cushion. White flowers. Splendid alpine. 6 in. .20 .50

Tomentosa. A choice dwarf with brilliant yellow flowers in the Spring. Attractive foliage. One of the best .25 .65

ACoNITUM - Bicolor. Blue and white. September blooming ...........................

Autumnale Spark's Variety. A fine tall growing variety with deep blue

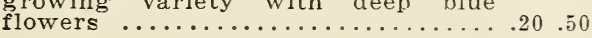

Fisherii. One of the best late varieties. Stocky dark blue flowers. Glossy foliage. 18 in. .................. 50

Lycoctonum. Yellow flowers. Rare. 2

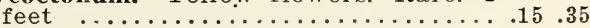

Napellus. Tall dark blue, almost violet. A vivid color. August, September. 4 feet. $1 / 4$ oz. $75 \mathrm{c} \ldots \ldots \ldots \ldots \ldots \ldots \ldots .15 .35$

Na p l 1 us Roseus. Wax-like pink

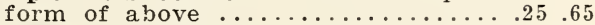

Napellus Praceox. Deep blue.. A choice early flowering variety ....... .25.65

Pyramidale. Tall, late blooming. Tiolet blue flowers. 5 feet .............30 .75

Vilmorinianum. Remarkable climber. Dark blue. Hardy in Southern States .30 .75

ADENOPHORA-Lilifolia. Fine shade of purple flowers. Blooms all summer.

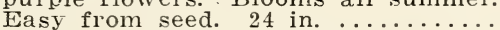

Potanini. Large Campanula-like blue flowers. Interesting. 1 foot ..... $15 \quad .35$

Verticillata. Small, drooping flowers. Purple. 24 in. ............................

ADONis-Vernalis. Large bright yellow. Spring blooming. 12 in. ...............

*AEThionema-Cordifolium. Lilac rose Fine rock plant. 6 in. ............25.70

Grandiflora. Large flowered, deep rose.

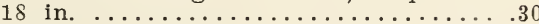

Persicum (Persian Candytuft). Light

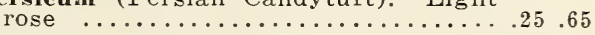

Purpureun. Fine rosy purple trailer. .30 .85 Saxatile. Dwarf and neat. Rose purple.

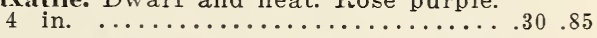

AE'THEOPAPPUS-Fulcherrimus. Large Centaurea-like flowers. Rose pink shades. 15 in. Fifteen seeds .... .25 
Agros'renuA - Atrosanguinea. Blood red. $1 / 4$ oz. $20 \mathrm{c} \ldots \ldots \ldots \ldots \ldots \ldots \ldots . .10 .15$

Bicolor. Variegated red and white ... $.10 \quad .25$

Coronaria. Bright clear crimson. Silver

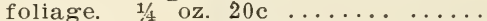

Coromaria Alba. Thite flowers. $1 / 4 \mathrm{oz}$ $20 \mathrm{c} \ldots \ldots \ldots \ldots \ldots \ldots \ldots \ldots \ldots \ldots \ldots \ldots \ldots \ldots \ldots$

Hybridal Wakcrí. B

ALIIUM-Neapolitanum. White flowering, colored stamens. Much used for

cutting. Requires protection. 20 in. .10 .25

IISINE Pinifolia. A delightful dwarf for the rockery. Covered with miniature white blooms in the Spring ..

ALSTROEMERIA Aurantiaca. Hardy and free blooming. Bright orange spotted crimson 3 feet.

Chilensis. Mixed heads of bloom in rose, orange, blush and yellow, with crimson and orange marlkings. Very attractive

* IIYSSUM-Argenteum. Neat for rockery. Yellow. 12 in. $1 / 1$ oz. $30 \mathrm{c}$.

Ilacum. A dwarf trailing mass of yellow. Glaucous foliage $\ldots \ldots \ldots \ldots \ldots$ low flowers

Pyremaicum. Charming rock plant.

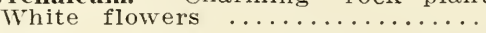

Repens. Creeping species. Yellow flowers ...................... Covered with bright yel

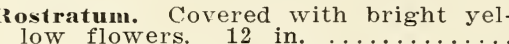

Saxatile Citrinum. Pale yellow flow-

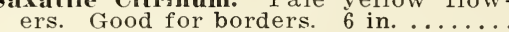

Saxatile Compactum. A very popular border plant. Compact heads of bright yellow flowers. $1 / 4$ oz. $30 \mathrm{c}$

Serpyllifolium. Neat alpine. Yellow. Gray foliage. 4 in.

Spinosum. Distinct species. Den se growth. White flowers. 6 in. ..........

INCHUSA - Angustifolia. Narrow leaf. Sky blue flower

Barrelieri. Small deep blue, early

Italica Dropmore. Very satisfactory. Clear shade of blue. Easy and free. 4 feet $1 / 20$

*Myosotiflora. New. Dwarf, c l e a blue Forget-me-not flowers. Very

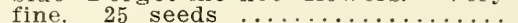

Opal. Light shade of blue. Varies. 4 feet ...... Everblooning. Lig h

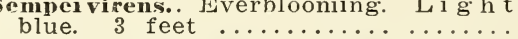

* ANDRosaCE Carnea. A neat rose colored alpine. Excellent in the rocks.

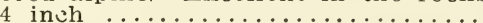

Corouspifolia. Abundance of $\mathrm{w}$ h it e

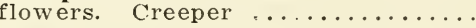

Glacialis. Pink flowers. Choice creep

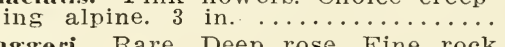

Lagseri. Rare. Deep rose. Fine rock

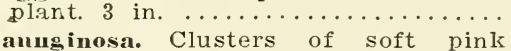

Lamuinosa. Clusters of soft pink
flowers. Free growing trailer. Silv-

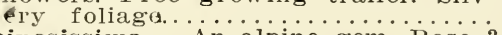

Spinosissima. An alpine gem. Rose 3

Villosa. iriniature white wooliy ros-

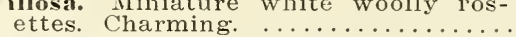

ANEMONE-Alpiua. Likes partial shade. Flowers a mixture of white and delicate pink. 6 in.

Coronaria St. Brigid. A splendid selected mixture of the double and semi double varieties. Unequaled colors. 12 in

Japonica. Fine fall blooming. We offer this in separate colors. White, rose, or mixed. 15 in.

* Montana. Pulsatilla type. Dark blue nodding flowers, 12 in.

* Pulsatilla Alba. One of the first in Spring. Splendid rock plant. 12 in.
Tr

10.15

10.15

10.25

$25 \quad .70$

$10 \quad .25$

25.65

10.25

.10 .25

.25 .65
* Pulsatilla Lilac. A delightful early bloomer. Deserves a place in every rockery. Easy from seeds .........15.40 * Sylvestris (Snowdrop). A dwarf, white alpine. Tery desirable. 8 in........20.50 *Vernalis. Dwarf. Paile purple flowers. Charming. 6 in. ...............25.65

ANTENNARIA Margueritarae. Beautiful white everlasting flower. Fine for

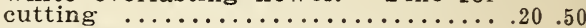

AN'THEMIS-Kelwayi. Especially fine for cutting. Golden yellow .......... 10.25

Kelvayi Alba. Fine white .........10.25

rinctoria. Bright yellow. Good for cut-

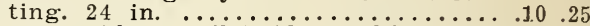
Nobiıs (chamomile) Clear white flow-

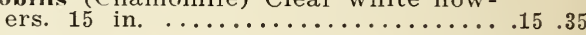

AN'THEIR ICUM-Liliago (St. Bernard's Lily) Small yellow flowers on spike

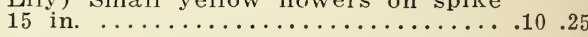

liliastrum (St. Bruno's Lily) Pure

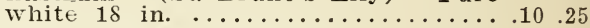

* AN'TIRIRINUM-Glutinosum. Pretty dwarf species. Yellow and white

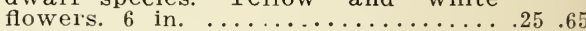

I'UC:YNEM-A IIrosamifolium. (Dog's Bane). Rare. Light red flowers. Frag:

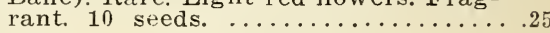

\section{AQUILEGIA}

The Columbine has a well deserved place il every garden by reason of its graceful and colorful appearance. The first group of Aquilegias lists the more hardy varieties.

Alpina. Graceful nodding flowers of a bright blue color. A fine rock garden

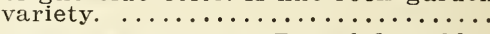

* Alpina Atrocoerulea. Dwarf deep blue A good rockery subject. $1 / 1$ oz. $35 \mathrm{c}$ * Ipina Superba. Blue and white. 1/4

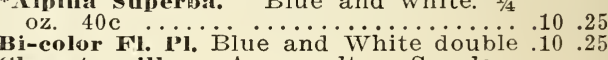
Clemataquilla. A novelty. Spurless flowers in mixed colors ............... .35

Hybrida Lucida Fl. Pl. Scarlet brown double. $i / 4$ oz. $50 \mathrm{c} \ldots \ldots \ldots \ldots \ldots \ldots .10 .25$ Nivea Grandiflora. Fine double white

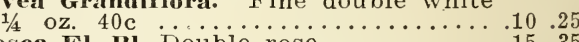

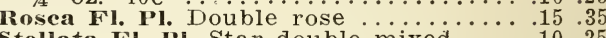
Stellata FI. Pl. Star double mixed .... .10 .25 Striata Fl. Pl. Double striped. $1 / 4 \mathrm{oz}$.

$40 \mathrm{c} \ldots \ldots \ldots \ldots \ldots \ldots \ldots \ldots \ldots \ldots \ldots \ldots \ldots \ldots \ldots \ldots$

vulgaris. Fine double mixed. i/4 oz.

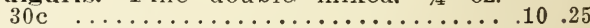

These Aquilegia are finer seed and to get the best results should be sown in a frame. We hold them in a frame until Spring when we line them out. They will bloom profusely.

Cauadensis. A pretty North American native. Yellow center with bright red spurs

Chrysantlia. Long spurred, yellow $1 / 4$ oz. $50 \mathrm{c} \ldots \ldots \ldots \ldots \ldots \ldots \ldots \ldots \ldots \ldots \ldots \ldots \ldots \ldots \ldots \ldots$ Chryautha Fl. Pl. Doubie yeliow

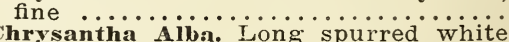
$1-8$ nz. $40 \mathrm{c} \ldots \ldots \ldots \ldots \ldots \ldots \ldots \ldots \ldots$ Chryantha Alba silver iueeil. Impröed long spurred white. The best pure

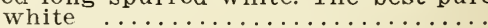

* Coerulea. Rocky Mountain Columbine. Long spurred blue, white center. A charming flower. $1 / 4 \mathrm{oz} .75 \mathrm{c} . . . . .$.

Coerulea IRose Queen. Striking rose shades. Extra fine. $1 / 4$ oz. $\$ 1.00 \ldots \ldots$

Coerulea Hybrida Fl. Pl. Long spurred doubles in various hues.

Farouhar's Pink. The finest collection

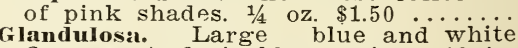
flowers. A desirable species. 12 in. Jetschaui. Large orange flowers with

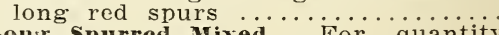
Long spurred Mixed. For quantity rrowing. Scott Wlliott Strain The finest Irs. Scott Elliott Strain The finest
mixture of long spurred hybrids with mixture of long spurred hybrids with
colors ranging from deep purple through pink, red, violet, to pure white. The flowers are large. The true strain $1 / 4$ oz. $\$ 1.75 .1$ oz. $\$ 6.00$ $20 \quad .50$ 10.25 15.40 .10 .25 .15 .40 $20 \quad .50$ 15.35 
skinmerii. Scarlet spurs. Yellow, with

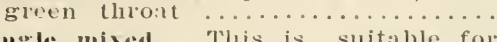

simgle mixed. Tlis is suitable for
quantity sowing. fiood eolor range. quallity sowing. fiood eolor range.

bouble mixci. lor sowing in the wild girdell. Hardy and dependable. 1 oz. $60 \mathrm{c} \ldots \ldots \ldots \ldots \ldots \ldots . . . \ldots \ldots$

* Vulgaris Compacta "Lulelweiss" New. One of the arliest. Erect sllow-white flowers. Light green foliage. A charluing lock plant. 15 in. Recommended

IRIBIS Alpina. (Rock Cress) Low growing border plant. Profusion of white bloom in early spriug

Aubrievioides. Fine rock plant. Purple

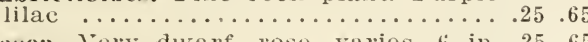

Rosea. Very dwarf, rose, varies. 6 in. .25 .65

* I IRENAIA-Montana. Dwarf, white, fine for dry, sandy situation. 8 in. .15 .40

Laricifolia. White trailer. Rockery. 5

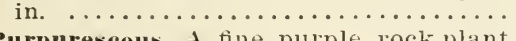

Purpurescens. I fine purple rock plant 3
in. $\ldots \ldots \ldots \ldots \ldots \ldots \ldots \ldots \ldots \ldots \ldots$

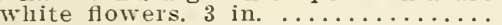

Serlyllifolia. Close growing tufts of green covered with clear white flowers in the Spring. Excellent in rocks. :15.40

Balcarica. Neat, compact tufts. Pro-

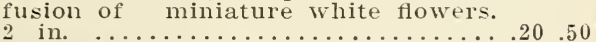

I RGEMONF-r'latyeeras. Large white flowers. Glaucous foliagc. 2 1-2 ft. . . .10 .25

ARMIRIA-A trosanguinea. Dark red flowers. Strong grower. Fine. 18 in. .25 .65

Bee's Ruby. Deep red shades. Taries. Recommended. 24 in. .............

Cephaloites (Round-head Thrift) Fine border plant. Deep rose. $12 \mathrm{in.} \mathrm{....}$

Dianthoides. Similar to Bee's Ruby

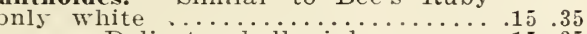

Formosa. Delicste shell pink .........

(iigranter. The tallest and largest variety. Fine for cutting.

* Laucheama. Compact tufts of bright green covered with rich rose colored Howers. Valuable in border or rock-

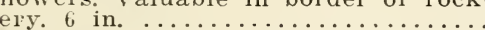
Iaritima. Similar to $\mathrm{A}$. laucheana but with pink flowers. Useful and colorful in the rock garden. 8 in.

ARNEBIA Echioides. A rare and very beautiful variety. Bright yellow flowers with clear purple spots.

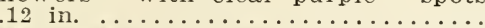

ARNIA-Vintana (Mountain tobacco) Showy Alpine. Large yellow heads .15 .35 ARTEMISIA-Absinthium. (Tormwood) Almost shrubby. Has white silky foliage

IsCLEII is-Incarnata. Tall reddish purple. Fragrant. ................ Tubcrosa. (Butterfly weed) Tery
showy bright orange flowers. An showy bright orange flowers. An American native Easy ........... rosy pink flowers. Creeper ........... Hexaphylia. White. Fine for cutting. Longifolia. Attractive border plant. dorata (Sweet Woodruff) Smail white

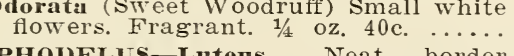

ISPHOJEIIS-Lutens. Neat border plant of easy culture. Bright yellow

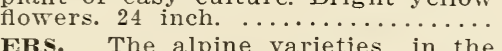

ASTERS. The alpine varieties in the following group of Asters are rapidrichly deserve as bright rock garden plants.

Apinus. Neat dwarf plant with large violet blue flowers. 9 in. $\ldots \ldots \ldots \ldots$ form of

Apinus albus. Clear white form of above $\ldots$ Dinu Beauty New. Exira fine

Mpinus Goliath. Delicate sol't blue Pkt P'kt latrige llowers.

Apinus Naney Perry. Clear light blue Attrietive.

Ipinus roseres. large, bright lose flowers

Ipims Mixed. Siplentid mixture of flne. lianed hybrids

Anellas Fine tall varicties mixed o

Dova Inglac lioseal. Fixtral good pink. 10.25

l'yramidalis. light blue tinted rose. . .15.40

'Towndendii. Riosy lilac. Liarge flow ers. Wisy and frec. 16 in.

Vumancusis. Perfectly formed flowers of ricil lavender, ycllow disk. Uiusual

harme flowered Mixed. A well balanced mixture of the tall growing types

* ISTIRARAhUS-Alpinus. A choice Alpine creeper: Pink.

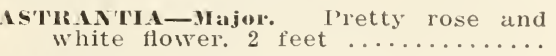

* IUBrzerIA. Because of their neat compact foliage and the rivid splash of color which they give in the Spring, the Aubretias are one of the best subjects for the rockery. A valuable alpine plant.

Bougainvillea. Dark, clear blue

crimson kinc. Extra fine rich crimson

beltoides. Clear lilac. Compact grow

Eyerei, Large violet flowers ........ .15 .35

iracea. Bright blue. Dwalf. 1/4 oz

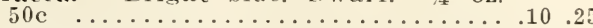

Hendersonii. Attractive lavender blue. .15 .35

Hybrida Graudiflora. Many shades of new large flowered varieties. 1/1 oz.

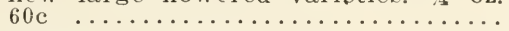

Leichtlini. Large carmine flowers.

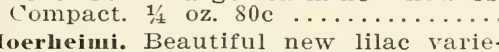

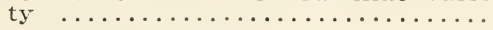

Irs. Lloyd Edwards. New crimson purple flowers. Choice. ..................

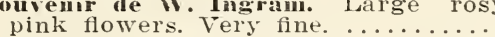

Whitewell Gen. Rosy purple with distinct white halo in the center. Fine.

AZILEA. Kaempferii. (Flame Azalea). A brilliant red. One of the best. In the Spring the plant is simply covered with gorgeous blooms

Mollis. One of the hardiest varieties. The blooms vary from a lovely pink to brilliant orange and yellow. This variety and A. Kaempferi should be sown in peat or woods loam under glass. They are splendid ornamenta shrubs. Récommended.

BAHIA-Ianata (syn. Friophyllus Caespitosum.) Neat yellow flowers, fine rock plant. 12 in.

BALSAMITA-Vulgaris. Old fashioned gray leaved plant smelling strongly

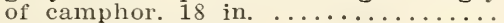

BAPTISIA-I ustralis. (False Indigo). bcrder plant. Foliage attractive. 30

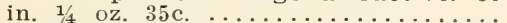

* BELlis Perennis. (English Daisy). Double white. $1 / 4$ oz. $50 \mathrm{c} \ldots \ldots \ldots \ldots \ldots \ldots$

Lonyfellow. Double rose $1 / 4$ oz. $50 \mathrm{c} . .10$

Mixed. $1 / 4$ oz. $40 \mathrm{c} \ldots \ldots \ldots \ldots \ldots \ldots \ldots . . \ldots \ldots$

Monstrosa. Thite, Rose or Red. $1 / 4 \mathrm{oz}$. $85 \mathrm{c} . \ldots \ldots \ldots \ldots \ldots \ldots .20 .50$

Etua. New. Brilliant red daisy. One of the best. 6 in. ......................... otundifolia Coerulescens. Charming

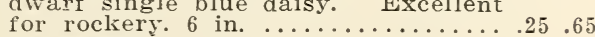

BELIJUM Minuatum. A neat, dwarf Alpine Daisy with a lilac ray. Especially fine in the rocks. 3 in. 

BETONICA - (Betony) Grandifora Su-
perba. Long stems of lilac rose flowers. The best Betonica ..........20.50

Rosea. Pretty rose spikes. Free 18 in. .20 .50 BOCCONIA-Cordata (Flume Poppy) Tall, cream. $1 / 4$ oz. 25 c .......... BOLTONIA-Asteroides. (False Chamo-

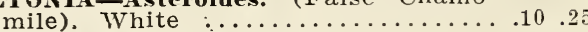

Latisquanıe. Pale pink. . . . . . . . .15 .35

BUDDLEYEA-(Butterfly Bush) Magnifca. Strong lavender color. Heavy crover Long spikes of lilac scented flowers in July-August. ..........

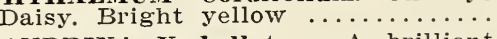

CALANDRINA Umbellatu. A brilliant crimson dwarf that is very showy.

CALAMINTHA-Alpina (Alpine Mint). A very pleasing dwarf Alpine. Clear lavender flowers that cover the plant

CAlCEOLARIA Polyrhiza. A rare and unusual Alpine. Brilliant yellow flowers on six inch stems. Pretty ......

CALLA-Aethiopica. (African Lily) Large white flowers. 36 in. ........

CALLIRRHOE - Involucrata. Trailer with attractive crimson flowers ....

CAMASSIA. Hybrida. A bulb of the lily family. Grows about two feet high Seed taken from fine named varieties. Colors range from blue to white

\section{CAMPANULA}

The following varieties are biennials

Calycanthema. ( $C u p$ and Saucer Canterbury Bells). An excellent strain. White, Rose, Blue, Striped or mixed.

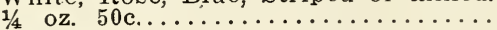

Longistyla. Drooping violet flowers. 3 feet ................................ The

Medium. (Caterbury Bells) Single. The best grower. Clear colors of white,
rose, blue, striped or mixed. $1 / 4$ oz. $25 \mathrm{c}$

Medium F1. Pl. The double variety. Attractive. White, blue, rose, striped, or mixed.

Iediun Deau's Hybrids. Fine range of colors from deep shades of blue to delicate tints of pink. 1/1 oz. $50 \mathrm{c}$..

Trachelium (Coventry Bells). Single blue. Vigorous habit. 2 feet ........... The following varieties of Campanulas are perennials.

Alliaraefolia. Creamy white. 2 1-2 feet

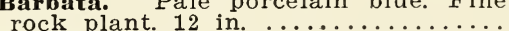
Bellardi Mirandi. $\ddot{A}$ charming $\ddot{\mathrm{Al}} \dot{ }$ pine. Silvery blue bell flowers. A continuous bloomer. 3 in. biue Alpine

* Bellidifolia. Choice light blue Alpine,

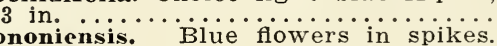

ononiensis.

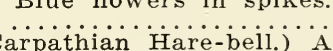
Carpatica. (Carpathian Hare-beil.) A popular variety. Dwarf in blue, white, or mixed. 1-2 oz. $50 \mathrm{c} \ldots \ldots \ldots$. Cenisia. (Mt. Cenis Hare-bell) Com-
pact choice Alpine. Distinctive blue flowers.

* Garganica. Excellent rock plant. Flowers blue with white centers.

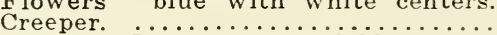

Glomerata. Large heads of blue flow ers. 15 in. $\cdots$ Erect, violet blue flow ers .............................

Lactiflora. For the border. Light atifolia. Abundance of large flowers in white, blue, or mixed. 24 in. ....

* Laurii. One of the best introductions in recent years. From Greek Islands. Resembles C. Rotundifolia, but the lavender flowers are larger, and turn
up. They cover the plant with a magnificent mass of color. 6 in. ....
Macrantha. Large purple flowers Pkt Pkt Splendid border plant. 3 feet. .......10 .25 Michauxoides. Delicate blue flowers.

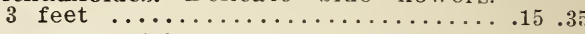
Mirabilis. Fine novelty from Caucasus. Light blue. 24 in. .......... 25.65

*Muralis. (Portenschlagiana) Upright delicate blue bells. Very desirable alpine. 6 in. Very rare. .........................

Nobills. Purple flowers ............15 .35

Nobilus Albus. Charming white nodding

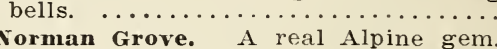

Norman Grove. A real Alpine gem.
Delicate blue flowers in mid-summer.

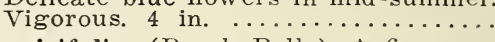

Persicifolia. (Peach Bells). A fine perennial in white, blue, or mixed. feet. $1-\delta$ oz. $50 \mathrm{c} \ldots \ldots \ldots \ldots \ldots \ldots \ldots . .15 .35$

Persicifolia "Telham Beauty". Large bells of beautiful china blue. Im-

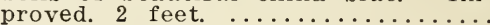

Persicifolia Fl. Pl. An attractive double flower in blue, white, or mixed ....

Primulaefolia (Primula leaved Bell Flower). A tall and graceful lilac

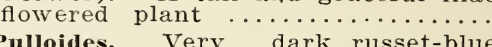
flowers. One of the choicest. 3 in. ..

*Pusilla. Attractive bright green foliage and pale blue flowers. Dwarf.

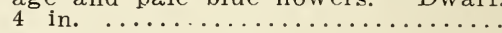

Pusilla alba. Delicate white flowers

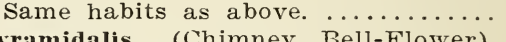

Pyramidalis (Chimney Bell-Flower) Fine for border. White, blue, or mix ed. 36 in. $1 / 4$ oz. $50 \mathrm{c} \ldots \ldots \ldots \ldots \ldots \ldots$

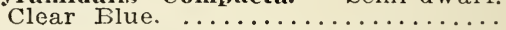

*aineri. Rare dwarf species with lavender blue flowers. 3 in. ..........

* Rhomboidalis. Dwarf. White, blue, or mixed. 6 in. ....................... Giant form of

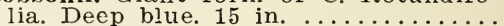

* Rotundifolia. (Blue bells of Scotland) A charming, graceful plant with pale

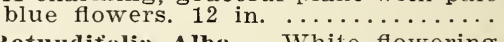

Rotumditolia Alba. White flowerin Saxifraga. Deep blue on trailing

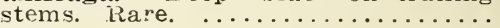

spicata. Heary spike of deep blue

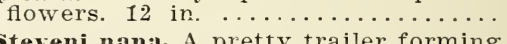
Steveni nana. A pretty trailer forming masses of bright blue flowers ....

Tommasiniana. Handsome clear blue dwarf. $\delta$ in. ......................

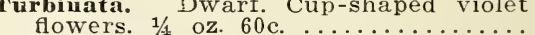

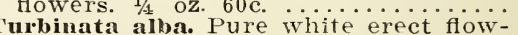

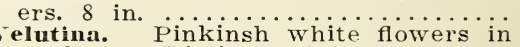
Velutina. Pinkinsh white flowers in * Waldsteiniana. Excellent rock plant.

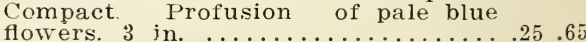

*ARLINA-Acaulis. An attractive dwarf for dry, hot situations. Ornamental foliage and silvery thistle-like heads. Good rock plant 6 in

\section{CARNATIONS}

Note. Carnations Vienna Market and Chabaud's are perennials, but give best result treated as Biennial. The Marguerites bloom in four months from seeds, and are best treated as annuals.

Maluaison. Tery showy doubles in a fine color assortment. Makes a very good cutflower. Blooms first season from seeds sown early. Mixed. $\ldots$.

Picotces. Finely striped and rarigated

vienna Market. Scented. Fine for cutting. Sow in July, August, blooms next season. Separate colors, red, rose, white, dark maroon or mixed.

rose, white, dark maroon or mixed.
$1 / 4$ oz. $\$ 1.00 \ldots \ldots \ldots \ldots \ldots \ldots \ldots \ldots \ldots \ldots \ldots \ldots \ldots \ldots \ldots$ 
Chabaud's lirenesh Markct. 'Taller' than Vienna, a rine scented stroin. Blooms same as Vienna. Separite colors, white, red, yellow sroumis, rose or mixed. 1/4 oz. $75 \mathrm{c} \ldots \ldots \ldots \ldots \ldots \ldots .15 .35$

striped. 1)ouble flowers, all striped. . . .15 .35

Chabaud's reddish Lilac ..........20.50

Chanband's Coehineal. . Cochineal car-

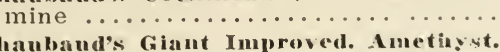
hanbaud's Giant mproved. Ametingt. bloom during summer montlis. Clear amethyst color

Chabaud's Giant Improved. Decp liose. A new improvement. Bloom is finely shapod, large, and has delicate clove scent $\ldots \ldots \ldots \ldots \ldots \ldots \ldots \ldots \ldots \ldots \ldots$

Chabaud's Giant Improved, Cardinal. A strong, brilliant colored carnation. Comes into bloom six months from seed. Huge, double type flower ....

Chabaud's Giant Improved Sulphur

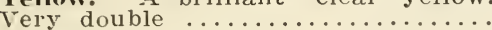

Iargnerite. Smaller than Chabaud's. Blooms in August and Sept. from spring sown seeds. Finely scented. Good stem. Separate colors, white, rose, crimson, yellow grounds, or

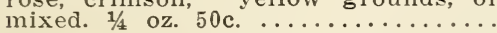

Grenadin. An intense double early variety equally fine for bedding, border or cutting. IVill bloom first season. Strong grower. Colors-Bright Scarlet, King of Blacks, Rosy Queen, White, or mixed 1/4 oz. $75 c^{2} \ldots \ldots . . .18$

All above contain a good percentage of doubles.

CARDUUS-Kerneri. (Kerner's Thistle) $10 \quad .25$

CASSIA-Marylandica. Erect plant with bright yellow flowers. 2 1-2 feet.

CA'TANANCHE-Coerulea. Good everlastings for cutting. July, August, 10-12 in. $1 / 4$ oz. $40 \mathrm{c}$. Blue, white or mixed.

CEDRONELLA-Cana. Deep red purple spikes. Fragrảnt. Foliage fine. 24 in. .20 .50

CENTIUTEA-Dealbata. Showy tufts of rosy pink flowers. 20 in. .........................

Yacrocephala. Large yellow heads.

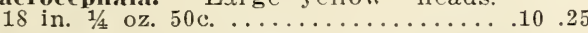

Iontana. A very useful perennial in the border. Easy. Blue. 1 oz. $50 \mathrm{c}$.. .10 .25

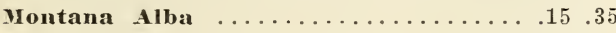

Yontana Mixed ..................10 .25

Ruthenica. New Roumelian species.

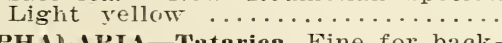

CFPHAl. IRIA-Tatarica. Fine for background of the hardy border. Large

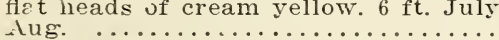

CERESTIUM-Biehersteini. Fine dwarf Cetton-like foliage. Pure white flow-

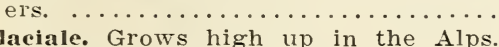

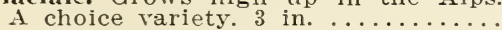
Tomentosum. (Snow-in-summer). Attractive silver gray creeper for rock garden. White flowers. $1 / 4$ oz. $50 \mathrm{c}$

CHAMAEPEUCE-Diacantha (Rosette Thistle) $1-2$ oz. $40 \mathrm{c} \ldots \ldots \ldots \ldots \ldots \ldots$.

Allioni. Brillian orange flowers on one foot stem. A most profuse bloomer. $A$ beauty in the rock garden ......

A. Semperflorens. Perpetual flowering

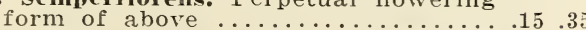

Linifolius. Alpine wallflower. Mauve .15 .35 * CHKISANTHEYUM-Vaximum. Shasta

Daisy. Alaska. $1 / 4$ oz. 40 c .............

Covent Garden Market. Hardiest, $1 / 4 \mathrm{oz}$.

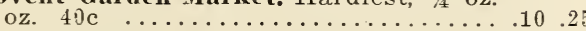

King Edward. A fine white daisy. $1 / 4$ oz. $40 \mathrm{c} \quad \ldots \ldots \ldots \ldots \ldots \ldots \ldots \ldots \ldots \ldots \ldots \ldots \ldots \ldots$

Lacinated. Fnds of petals split and curled, giving the flower a ragged appearance. 1/4 oz. $75 \mathrm{c} \ldots \ldots \ldots \ldots \ldots . .15 .35$

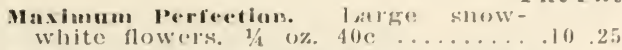

Pkt Pki

Ir.s. ('. Lothian Bell. The brest exampl. of English selection of the slightly lacinated type. $3 / 40 \% 500$

10.25

Ihe Spenker. One of the best lixtrat large: pure: white. $1 / 1$ o\%. $75 \mathrm{e}$

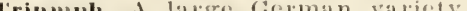
oz. $40 \mathrm{C}$

$.10 \quad .25$

The Shasta Daisies will not prove 100 per cent true from screls, but the best selections will show a fine proportion of worth-while plants. CHIR ISANHEVI M-Iudienu. Hardy Chinese varieties in mixture

fencauthemu!n Praceox "Jewelo" lially Howering form with smaller flowers. $1 / 4$ OZ. $60 \mathrm{C}$

Lencanthemun hybridus. Pure white early flowering Marguerite.

Jiponicum. Hardy Japanese varieties, mixed

Japonicu!n. Praeeox. liarly flowering form of Japanese sorts, blooms first season from early sowings

Japanese Mountain. A beautiful miniature item, 12 in.

CIMCIFIGIA-Raeemoxa. Tall growing native. Graceful spikes of white flowers. This will do well in full sliade. 4 feet.

( IRSIUM-Velenowski. (Velenowski's Ornamental Thistle) White, chinging tc violet. $1 / 4$ oz. $50 \mathrm{c}$

CI.IX'TONIA Virginiea. (Spring Beauty) This charming native with its bright rose flowers is one of the first in the Spring. 6 in.

*CODONOPSIs-ovata. Very pretty pale purple flowers. Needs protection.

COLCHICUM-Antumnale. Fall crocus .15 .35

Speeiosum Magnificun. The finest of the colchicums

CONVALLARIA-Majalis. Lily of the Valley …...................... (Solomon's Seai). We

Polygonatum. (Solomon's Seal). We have had many calls for this pretty ${ }^{2}$

COREOPSIS-Lanceolata. ('Tick Seed) Clear yellow. $1-2$ oz. $20 \mathrm{c} \ldots \ldots \ldots \ldots$

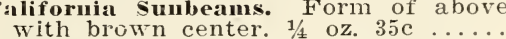

Perry's Double. Beautiful semi-double flowers of a golden yellow which make splendid cut flowers. $1-8$ oz.

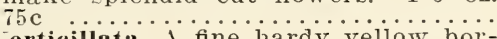
Verticillata. A fine hardy yellow bor-

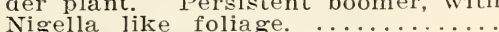
Nigella like foliage. …... (Crown ietch) Pleasing li]ac-purple flowers. $2 \mathrm{ft}$. flowers. Glaucous foliage. 9 in.. chroleuca. Charming rock plant. Delicate pale yellow. 6 in.

Thatictrifolia. Beautiful new species. halictrifolia. Beautiful new species.
Bright yellow. Blooms all summer. Slight protection. 12 in. ........... Syos-Dahlioides. New and interest
ing tuberous rooted perennial. Range of brilliant colors. 2 feet.

CRUCIANELIA-stylosa. Large heads of bright pink flowers. 12 in.

\section{DELPHINIUMS}

Helladonna. Long a favorite because of its lovely sky-blue color. $1 / 4 \mathrm{oz}$

Bellamosum. Dark blue form of above $1 / 4$ oz. $\$ 1.00,1$ oz. $\$ 2.50$

English Hybrids. This is a fine collection from the leading varieties of Hybrid Delphinium. Perfectly hardy. and containing a good percentage of choice doubles. $1 / 1$ oz. $75 \mathrm{c}, 1$ oz. $\$ 2.25$ Formosum. In locations not subject to mildew this dark blue flower is sumildew this dark blue flower is su-
perior to Bellamosum. The true variety. $1 / 1$ oz. $\$ 1.00 \ldots \ldots \ldots \ldots \ldots \ldots$ 
Chinensis. (Grandiflorum) Finely cut foliage. Will bloom first season. Good for cutting. Colors, white, azure, dark blue, blue Butterfly or mixed. 18 in. $1 / 4$ oz. $35 \mathrm{c} \ldots \ldots \ldots \ldots \ldots \ldots \ldots$

Nudicaule. Fine dwarf from California. Bright scarlet. $1 / 4$ oz. $75 \mathrm{c}$.

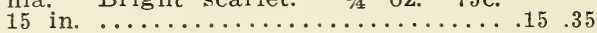

Nudicaule "Chamois" A distinct break Beautiful apricot color ............25 .70

Nudicaule "Lemon Gem". Flowers clear yellow. A beauty. 15 in. ...........25.70

\section{HYBRID DELPHINIUM}

In the following list of selected Delphinium you will find the best types and quality of these exquisite flowers. They are dependable seeds-a high rate of germination, a wide range of fine colors, and size and form which are important in judging Delphinium. Each suceeding year marks a decided development in the hardiness and quality of these varieties. They will not come absolutely true to type, but they will show many fine doubles and semidoubles of large size.

We would recommend that they be sown where they can be protected, and should not be sown too late in the summer. Early Spring. after all danger of frost is gone, is the idea time to sow these seeds. Many varieties will bloom the first year.

Finest English Doubles, Light blue shades. Really fine. $1 / 4$ oz. $\$ 2.00 \ldots \ldots .25 .70$

Finest English Doubles, Dark blue shades. Immense flowers. $1 / 4$ oz. $\$ 2.00 \quad 25 \quad .70$

Finest English Doubles. All colors mixed. A splendid mixture. $1 / 4$ oz. $\$ 1.75$

Hollyhock strain. As it becomes more widely known, this variety is being accepted as one of the best of Del phiniums. Huge double flowers on long spikes, in colors that range from deep purple through the blues to delicate pinks. $1 / 4$ oz. $\$ 2.50 \ldots \ldots$.

Wrexham Hybrids. Taken from true stock which includes flowers of exceptionally large size. This strain of double and singles rivals the best in the Delphinium world. $1 / 4$ oz. $\$ 2.00$

Zalil. (Sulphureum) Sulphur yellow flowers. A beautiful species from Afghanistan. Slow to germinate

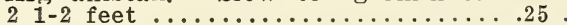

\section{NAMED VARIETIES}

The following Delphinium are grown in England. They represent the finest of their type and are unequalled for their quality of bloom They will not come true to type but the named sort will predominate.

King of Delphiniums. A giant Gentianblue and plum. Large white eye

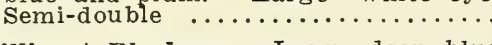

Millicent Blackmore. Large deep blue with inner petals shading from pale

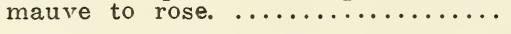

Brilliance. Brilliant shade of blue with large white eye. Semi-double......

Reverend Wilks. Richest purple, beautifully shaded with plum. Large black eye. A fine semi-double ......

Monarch of All. Large flowers of brilliant shades of blue. Double ....

Mrs. James Kelway. Pink inner petals
surrounded by large pale blue petals.

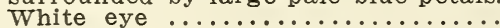

Queen Mary. Exquisite silvery blue. Large flowers with white center....

Rev. E. Lascelles. Deep purple blue with attractive white eye. Double .. .25 .65

one packet each of these eight choice varieties ................. \$1.75
The Dianthuses are not used enough in the rock garden or the border. There are many delightful varieties in this group which are very easy from seed and which give to the garden charm and color

Note, Dianthus Scotch type, Dbl. Dwf. Erfurt, Single Rock, Superbus, Caesius, and Cyclope all come under the head of what is known as "hardy" or "grass" pinks. Dentosus and Deltoides are distinct, with finer cut foliage of dark green, and smaller flowers. All flower the second season, a few the first. Alwoodii. Really a hardy perennial
carnation. A new race producing $75 \%$ of double flowers in almost every

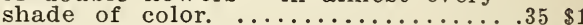

Alpinus. Dwarf Alpine. Handsome rosy purple flowers. 3 in. ................25.65

Arenarius. Desirable rock plant. Pale

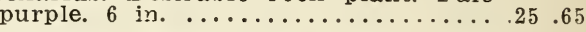

Arvenensis. Exceptionally dwarf. Pink flowers. Grey foliage. 2 in $\ldots 25.65$

Caesius. The true cushion pink. Little solid balls of spiky glaucous foliage.

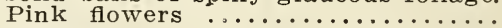

Caucasicus. Compact. Covered with deep rose flowers. Fine rock plant. .25 .65

Crimson Bedder. Brilliant crimson. A new hybrid of merit. 12 in. .......25.65

Cruentus. Blood red flowers in clus-

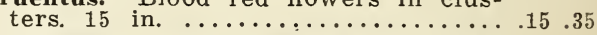

Deltoides. Dwarf dark green foliage covered with bright pink flowers in June. Easy. 1/4 oz. 50 c ................ 10.25

Deltoides Alba. White flowers with

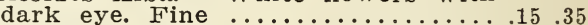

Deltoides "Major Stearn's Variety." Very pretty with dark brown foliage and brilliant crimson flowers. Rec-

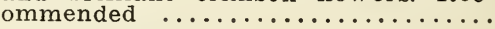

Dentosus Hybridus. (Amoor Pink) A beautiful old species. Colors vary

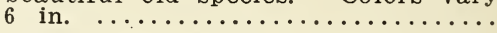

Double Dvarf Erfurt. Finest doubles mixed. The best commercial strain. $1 / 4$ oz. $75 \mathrm{c} . \ldots \ldots \ldots \ldots \ldots \ldots \ldots \ldots \ldots \ldots .10 .25$

Early Blush. Scotch type. Light pink .15 .35

Glacialis. A rare alpine. Flowers

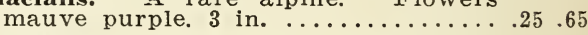

Graniticus. Neat branching habit Bright red flowers. 8 in. ...........20.50

Microlepis. An alpine gem. Compact. Soft pink flowers. 6 in. ............25.65

Neglectus. Cherry red flowers on diminutive tufts. Charming. 3 in. ...... .25

Plumarius. "Cyclope Hybrids" Fine single pink and red. Strong grower

lunarius. "Highland Queen." An excellent, easily grown gem for the rock garden. Large brilliant crimson flowers, shaded maroon at the center. A long and free bloomer center. A long and free bloomer.
Recommended. 8 in. . . . . . . . . . .

Plumarius. "Ipswich Crimson." New variety. Deep scarlet flowers. Border carnation of merit. 12 in. .......

Plumarius. "MIrs. Sinkins". Pure white, clove-scented. Fine for cutting. 12 in $\ldots \ldots \ldots \ldots \ldots \ldots \ldots \ldots$

Plumarius. "Semperflorens." Singles in carmine shades. 1 oz. $50 \mathrm{c} \ldots \ldots$.

Plumarius. Seoticus fl. pl. The finest Scotch type mixed. Selected seeds. A
high percentage of doubles. 25

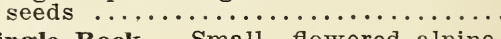

Single Rock. Small flowered alpine.

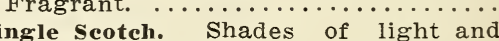
Single Scotch. Shades of light and Subacaulis. Charming dwarf species.

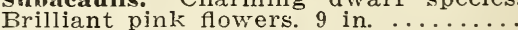
Sundermannii. Rare Macedonian specSundermannii. Rare Macedonian spec superbus. Beautiful purple fringed petals. Very fragrant. 12 in. .........20.50 
sweet Wivelsfeld. New. I rumarkable hybrid that has become immensely popular. Jistra larke Howers in a brilliant mixture. Delicately fringed. $A$ fine cutter, and most attractive in the garden

DINNIIIS HAIBATIS - Sweet William)

Johnson's Ginnt (true). The tinest of the Sweet William mixtures. Giant Howers in marvelous colorings. Brilliant erimsons, white margined reds, pinks, etc. $1 / 4$ oz. $30 \mathrm{c}, 1 \mathrm{oz} .75 \mathrm{c} \ldots$.

Joluson's Giant (Stock Seeds) Sared for oul own sowing. Takell from best individuals only. The best mixture of Sweet Williams. $1 / 4 \mathrm{Oz}$. $50 \mathrm{c} .$.

Wialcu. Bright crimson, centers with white margins A fine border, $10 \mathrm{in.}$ $1 / 4$ oz. $30 \mathrm{c} \ldots \ldots \ldots \ldots \ldots \ldots \ldots \ldots \ldots$

Holborn Glory. A very large flowered auricula-eyed type. Brilliant colors.

l'ink Beauty. Rosy salmon pink. 1/4 oz. $30 \mathrm{c}$

searlet Benuty. Bright scarlet. Not as well established as the other named sorts. $1 / 4$ oz. $30 \mathrm{c}$

louble White. $1 / 4$ oz. $50 \mathrm{c}$

Harlequin. Nulti-colored. $1 / 4$ oz. $60 \mathrm{c}$

Nigrescens. Double dark velvet Mrroon. $1 / 4$ oz. $25 \mathrm{c} \ldots \ldots \ldots \ldots \ldots \ldots \ldots \ldots \ldots$

Latifolius Atrococcinneus. Pink-like
dark green foilage, with double velrety crimson flowers. In bloom from June till snow fall. The everblooming Sweet William. Fine for cutting

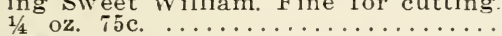
dwarf evergreen shrubs. In the Spring the plant is covered with clusters of fragrant, delicate pink flowers. Ideal in the rockery. Worth trying. Highly recommended. 15 seeds.

DIGTTALIS-(Foxglove). Gloxinaeflora. Fine spotted. White, rose, purple or mixed. $1 / 4$ oz. $30 \mathrm{c}$

The shirley. A new and improved form of above. $1 / 4$ oz. $50 \mathrm{c} \ldots \ldots \ldots \ldots \ldots \ldots$

Shirley. Specially selected. This will ers than above. Impossible to furnish

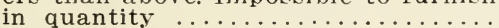

Grandiflora. (Dwarf). Yellow. $1 / 4$ oz. $40 \mathrm{c} \quad \ldots \ldots \ldots$

Buxbaumii. Buxbaum's Golden Yellow

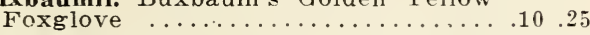

Ferruginca. Rust color. $1 / 4$ oz. $40 \ldots \ldots .10 \quad .25$

Hybrida Lutz. New hybrids, in salmon shades. $\quad \ldots \ldots \ldots \ldots \ldots \ldots \ldots \ldots \ldots$

Isabellina. A fine yellow. changing to chamois, claimed to be the best yet introduced. 3 feet.

Lanata. Densely flowered racemes. $1 / 4$ oz. $60 \mathrm{c} \ldots \ldots \ldots \ldots \ldots \ldots \ldots \ldots \ldots \ldots$

Maculata. Finely spotted dwarf, mixed $1 / 4$ oz. $30 \mathrm{c} \ldots \ldots \ldots \ldots \ldots \ldots \ldots \ldots \ldots \ldots \ldots \ldots \ldots$

Monstrosa. Like Gloxinaeflora, but with the addition of one very large flow-
er, well opened at top of spilie. $1 / 4$ er, well opened at top of spilie.

Siberica. (Siberian Foxglove). Rare species, flowers purple. Biennial ....

* DiCENTRA Eximea. (Dielytra). Dwarf everblooming bleeding heart. $1 / 4 \mathrm{oz}$.

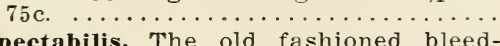
ing heart. 10 seeds $10 \mathrm{c}: 25$ seeds $20 \mathrm{c}$ ing heart. 10 seeds $10 \mathrm{c}: 25$ seeds $20 \mathrm{c}$;
100 seeds $75 \mathrm{c} ; 1000$ seeds $\$ 4.50 \ldots \ldots$.

DICTA INUS-Fraxinella (Gas Plant). Leaves are lemon scented. Abundance Leaves are lemon scented. Abundance
of blooms. Rose, white, or mixed. $1 / 4$ oz. $75 \mathrm{c} \ldots \ldots \ldots \ldots \ldots \ldots \ldots \ldots \ldots \ldots \ldots \ldots$

DIPSACUS-Lacinatus. ( Luacinated Teazel). Tall rose colored flowers, ornamental.

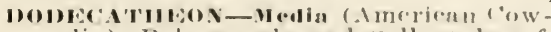
slip). Palo purple and yellow dware, Farly spring. 12 in.

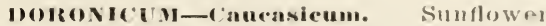
like yellow flowers on terminal stems in early spring. Very liard to handle. 25 sceds $15 \mathrm{c}, 75$ seeds 40 :

Plantagineum Excelsam. Golrlen yellow flowers. Especially fine for cutting. 15 in. 30 secds

* I) I COCEPIM I, M- I r tarian Dragon's Head). light blue flowers. 12 in.

Ruyschima. Dark violet blue. Neat for borders. 8 in.

DRYAS Octopetala. (Description by Jr. Louis Brand, who collected this seed in the Rockies). A prostrate alpine shrub with small oak-like leaves, and inch wide white roses on two inch stems. The tuffy whirls of seeds are very decorative after the flowers have passed. Undoubtedly one of the the aristocrats of the rock garden. Prefers limestone.

Sundermanni. A hybrid of $D$. octopetala and $D$. drummundii. Larger flowers of pale yellow. Prefers limestone soil also.

ECHINOPS-(Flowering Thistle)

Sphacrocephalus. Light blue, snill.

Ritro. (Blue Globe Thistle). Ball shaped flowers of steel blue. $3 \mathrm{ft}$. . . 10.25

Humilis Cyanae (Dwarf Globe Thistle) $.10 \quad .25$

Exaltus. Dark blue, blue ribs ........15 .35

Giganteus. Largest of the family . . . .10 .25

*EPILOHIUM-N1pinus. For a moist situation in the rockery this alpine is ideal. Dwarf and showy. New ......

obcordatum. Excellent dwarf for shady spot. Large rose-colored flowers. Fine. 6 in.

EREMURUs Bungeii Perfecta. One of the largest perennials. Spikes reaching $8 \mathrm{ft}$. Yellow. 150 seeds $\$ 1.00 \ldots$

Himalaicus. Very long spikes of pure white. Real hardy. A desirable addition. 25 seeds $20 \mathrm{c}, 100$ seeds $50 \mathrm{c}$

Robustus. A fine tall sort. Rose flow-

Alpinum. True Alpine thistle, turns

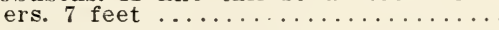

Wallace's Hybride. Wonderful range of

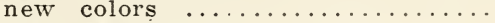

ERIGERON-Coulterii (Flea Bane). Tery early white, fine for cutting .....

Speciosus Hybridus. Lilac and blue shades

Qukeress. Tall, long stemmed. Rosy Lilac

*ERINUS-Alpinus. (Alpine Liver Balsam). Purple, dwarf, free flowering

* Apinus Albus. White form of above

* Alpinus Carmineus

EIROIIUM-Manescavii. Has a fine rose colored flower. The foliage is of a delicate design

*ERPETION -Reniforme. (Australian Pansy) Lilac

*ERYSIMUM-Pulchellum. Free flowering yellow ...................................

Purpureum. Deep purple. Neat rock plant. 4 in. .....

ERYNGIUM. (Sea Holly) All items in this are fine for winter bouquets.

Tripartitum. Stem branching and flowers blue. Branches and rebranches in threes. 30 in. all blue after flowering .....................

Bourgati. Blue bracts and divided glaucous leaves. Heads small and very numerous. $1 / 4$ oz. $75 \mathrm{c}$

Giganteun. True silver thistle

Planum. Dark blue, large .....

Planum Roseum. Rosy gray, new

Anethystinum. Light blue, slender

\section{5}



*ESCHSCHOLTzIA-Caespitosa. A dwarf
with small yellow flowers. Very early

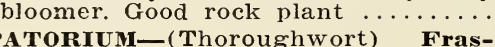

EUPATORIUM-( Thoroughwort) Fraserii. White, fine for cutting .......10.25 Ageratoides. White Snakeroot $\ldots \ldots \ldots .10 \quad .25$ Coelestinum. Fluffy heads of blue flowers in late fall, fine for cutting ... .10 .25

Purpureum. Tall, French Purple, fine .15.35

EUPHORBIA. Polychroma. New. One of of the best yellows for the rock garden. Compact shrubby plants covered in Tune with many brilliant yellow flowers. Highly recommended.

FERLLA-Gigantea. (Giant Fennell). Fine for tall groups, or for lawn specimens. 10 seeds $35 \mathrm{c} \ldots \ldots \ldots \ldots \ldots$

*FRANCOA-Ramosa. (Bridal Wreath).

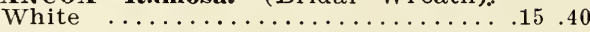

Ramosa Hybrida Rosea ..........20.50

* FRAGARIA - Indica. (Indian Strawberry). Yellow flower, small scarlet fruits. Very ornamental creeping

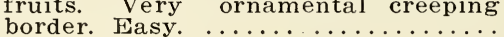

FUNKIA-Undulata Variegata. Dwarf, green and white, purple lavender

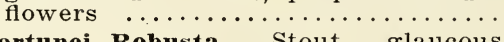

Fortunei Robusta. Stout glaucou
leaves. Lilac colored flowers. 12 in.

GAILLARDIA-(Blarket Flower) Grandiflora. Hybrids of Lady Rolleston. difora. Hybrids of Lady Rolleston.
The best possible mixture. $1 \mathrm{oz} .50 \mathrm{c}$

Compacta. Compact grower, free. $1 / 4$ oz. 35 c $\ldots \ldots \ldots \ldots \ldots \ldots \ldots \ldots \ldots \ldots \ldots \ldots$. $\ldots \ldots$. ter no colored zones. $1 / 4$ oz. $50 \mathrm{c}, 1 \mathrm{oz}$.

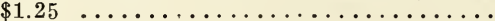

Portola Hybrids. A new strain of large flowering Gaillardia having a color range from reddish bronze to a deep gold. Very satisfactory as a cut flower. $1 / 4$ oz. $\$ 1.00 \ldots \ldots \ldots \ldots \ldots \ldots$

Semi Plena Mixed. Double and semidouble forms. Unusual and very pret-

The Dazzler. Brilliant red. A wonderful cut flower. New. Recommended ....

Burgumdy. New. Shining wine-red Gaillardia. The first all red Gaillardia introduced. One of the finer introductions from Europe. Will show about $70 \%$ true brilliant red flowers. Rec-

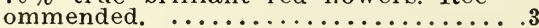

GALEGA-Ofricinalis. (Goat's Rue). Light lilac blue. Locust-like foliage. 18 in.

* Off. Nana Rosea. Dwarf, double, rosy lilac. Fine for cutting. $1 / 4$ oz. $75 \mathrm{c} \ldots$

Orientalis. (T'rue). Bluish purple,

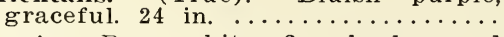

Persica. Pure white, fine background 36 in. $\ldots \ldots \ldots \ldots \ldots \ldots \ldots \ldots \ldots \ldots \ldots \ldots \ldots \ldots \ldots \ldots \ldots \ldots \ldots$ yellow markings $\ldots \ldots \ldots \ldots \ldots \ldots \ldots \ldots$

Asclepidea. Blue

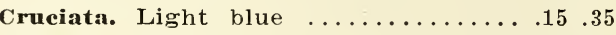

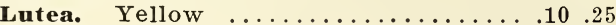

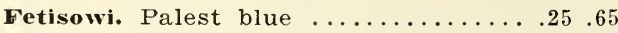

Freyniana. Clear bright blue .......25.65

Lagodechiana. Creeping Gentian, with large flowers of bright blue. A fine rock plant A. M. R. H. S. $21 \ldots \ldots$

Purpurea. Purple above, tube yellowish $\ldots \ldots \ldots \ldots \ldots \ldots \ldots \ldots \ldots \ldots \ldots \ldots \ldots$. Przewalski. Brilliant sky blue in ra-

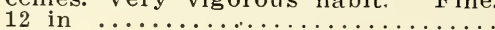

Farreri. A splendid trailer of delicate pale blue with clear white throat.

GERANIUM Sanguincum. A native gem well adapted for the rockery. Handsome foliage and purple red flowers.

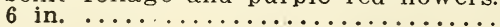
.30
*GlACM-Mrs. Bradshav. A fine scarlet perennial. Double. Easy from seed. $1 / 4$ oz. $50 \mathrm{c} \ldots \ldots \ldots \ldots \ldots \ldots \ldots \ldots \ldots$

Lady stratleden. A bright soft yellow. Double. Excelle1.t. $1 / 4$ oz. $\$ 1.00 .20 .50$

Heldrichii. Brilliant orange ........10.25

Heldrichii Superbum. Extra large

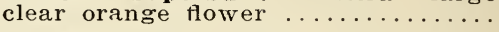

Montanum. New. Dwarf Alpine speccies with large yellow flowers. Inter-

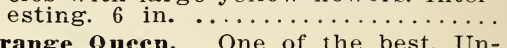

Orange Queen. One of the best. Unusual shade of orange ..............

GLAUCIUM-Burbank's Hybrids. Poppy-
like perennial with various colored cup-shaped flowers. Easy and free ..

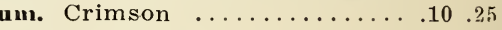

GLOBUIARIA-(Hairy Flowered Globe Flower.) 'Trycosantha. Dark blue .. .10.25

* Cordicolia. Fine and easy dwarf border. Neat rosettes of dark green (evergreen) leaves, round flowers of dark blue on clean 8 in. stems. Re-

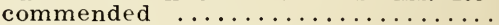

*GNAPH.ILITI-Decurrens. White everlasting.

GUAL'Therit. Procumbens. (Wintergreen). Creeping evergreen with red
berries in the Fall. The North Amberries in the Fall. The North Am-

GUNNERA-Seabra. (Giant Rhubarb) Immense. Good for back border. 5 feet.

GYPSOPHII/A - Paniculata. (Baby's Breath). The common single white, fine for cutting. $1 / 4$ oz. 25,1 oz. $60 \mathrm{c}$.

Paniculata. F1. Pl. Double form of

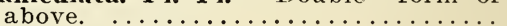

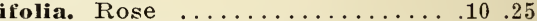

*Repens. Very dwarf, white ....... 10.25

* Cerastoides. Dwarf Alpine. White. veined red. 3 in. ............. 20.50

HEDYSARIUM -Coronarium. (French

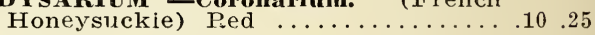

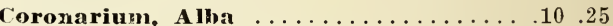

Multijugum. Flowers rosy purple.

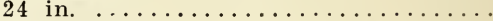

*Neglectum. Neat dwarf. Rosy purple

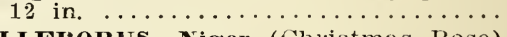

HELLEI:ORUS-Niger (Christmas Rose)

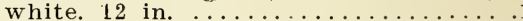

Hybridus. All colors mixed. 15 in. . . . 10.25

Viridis. (Green Hellebore). With green flowers

HELENIUM- (Sneezewort) Autumiale.

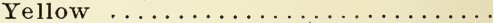

Hoopesii. Clear yellow on terminal

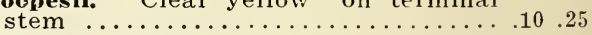

Riverton Beauty. Yellow with black

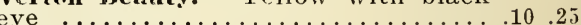

Fiverton Gem. Old gold and wallflow-

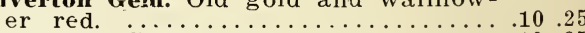

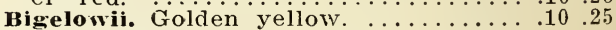

*HELIA NTHEMUM - (Sun Rose) Mutabile Mixed. All colors from yellow to deep rose. Fine border. 1/4 oz. $40 \mathrm{c} .10 .25$

Ruby. Selected from ruby shades. 10" .25 .65

Rose. Selected from best rose shades. $12^{\prime \prime}$ Selected from best rose shades.

*HELICHRYSUM - Lanatum. Perennial everlasting ...................... Angustifolium. Dwarf, foliage white. flowers yellow $\ldots \ldots \ldots \ldots \ldots \ldots \ldots \ldots$. . . . . . ed only - (Hardy Sunflower). Mix-

HELIAN'THELLA-Quinguaenervis. Large yellow flowers on $3 \frac{1}{2} \mathrm{ft}$. stems. Fine and very hardy

GLIOPSIS - (Orange Sunflower) Pitcheriana. Deep yellow flowers ...... Pitcheriana, w. Ladhams. A new, large

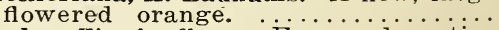

Scabra Zinniaeflora. Free and continuous bloomer. Very showy ảeep yellow. 30 in. $3 \ldots \ldots \ldots \ldots \ldots \ldots \ldots$. low. Stately in back border. 5 feet .10 .25 
11900 Pkt Pkt Lily). Fragrant golden yellow. Fine for the border or for cutting. 216 feet. 25 seeds $10 \mathrm{c}, 100$ seeds $35 \mathrm{c}$

Thunbergii. ' $T$ a 11 e $r$ and a deeper orange. IV ill not come true from seed. 25 seeds $10 \mathrm{c}, 100$ sceds $35 \%$

IIVITICA-'Iriloba. This delicate larendel American native is very popular. Fine for rock or wild garden. Dwarf $\ldots \ldots \ldots \ldots \ldots \ldots \ldots \ldots \ldots$

HEIRACILUM - Mattegassiamum. Very large foliage Huge white flowers.

6 feet $\ldots \ldots \ldots \ldots \ldots \ldots \ldots \ldots$
Wilhelmsii. Ornamental tiall

HERNIARIA. GIabra. A unique carpeting plant. Forms mat of pretty dark green foliage. Trailer

HESPEIRIS-Matronglis-(Sweet Rocket) Rose, white, violet or mixed. $1 / 2 \mathrm{oz}$ $30 \mathrm{c}$

vivea. Very l'are Dame's Violet known kotanically for years but just introduced to cultivation. Pure white blooms in May and June when white is scarce. Blooms like phlox Miss Lingard. Very sweet scented. A fine new perennial. 24". Easy

*HEUCHERA - Brizoldes (Coral Bells) Bright pink flowers on gracefu stems. Excellent for cutting. $1-8 \mathrm{oz}$ $\$ 1.25 \ldots \ldots \ldots \ldots \ldots \ldots \ldots \ldots \ldots \ldots \ldots \ldots \ldots \ldots \ldots \ldots \ldots \ldots$

Convallaria Carnea. (Pink Lily-of-theValley). New and beautiful. $15^{\prime \prime}$.

racillima. Fine pink sprays. Grace-

Sanguinea (Alum Root). Bright scarlet. Very ornamental. $1-8 \mathrm{cz}$. $\$ 1.50$

Sanguinea Aba. Delicate white flowers

HIBISCUS - Giant Meehan's Mallow Meehan's Mallow. From selected reds. $1 / 4$ oz. $50 \mathrm{c} . \ldots \ldots \ldots \ldots \ldots \ldots \ldots \ldots \ldots \ldots \ldots \ldots$

Crimson Eye. White, with red eye. 1/4

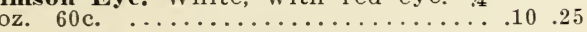

HIERACIUM - Aurantiacum. Dwarf. Deep orange flowers. Easy from

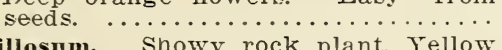

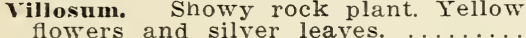

\section{HOLLYHOCK}

Long a favorite, this handsome perennial is one of the most useful in the back border. Great improvement is being made in the selection of choice double plants and brilliant new colors. In the following list you will find the best types of Hollyhocks grown.

Chater's Doubles. Large double flowers in the following colors-Crimson, in the following colors-Crimson, Rose, White, Maroon, New port Pink,
Salmon, Yellow or Mixed, $1 / 4$ oz. $40 \mathrm{c}$,

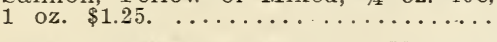

Doubles in Novalty Colors. Unusual shade and striking colors in large perfectly formed double flowers. Carmine, Chamois, Appleblossom, Lilac, Purple, Nankeen Yellow, Salmon Rose, Silver on Dark Ground,

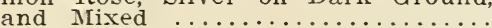

Single Hollyhocks. Large showy growers with full spikes of bright colors. Free blooming and easy. White, Yellow, Maroon, Pink, Scarlet, Rose, low, Maroon, Pink, scarlet, Rose,

Double Exquisite. This popular item increases it's admirers every year. Large intensely double flowers of a beautiful mixture of bright shades. are supported on long graceful stems. Perfectly hardy and a delight

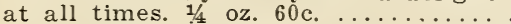

Imperator. A flue recent introduction. 'N broad collar of frilled and fringed petals with a large: double: easter rosette. There: are many attractlve eolor combinations, canary yellow and pink, dark scarl..t and creatm, and others the center rosette belus a different color than the fringed petals. Recommended. Alixed only

ricifolia. The true fig leaved hollyhock, deep yellow. Single. $6 \mathrm{ft}$.

* Horminu-ryrenacum. A pretty violet blue plant for either rockery or border

*HYACINTHUS - Amethystinus. Pretty dwarf bulb. Unusual shade of blue. 6 in.

Candicans-(Cape Hyacinth). Lárge Snowdrop-like flowers on tall spikes. 3 feet

H IPERICUM-Elegans. Bushy perennial with single yellow flowers, good.

Fragile. Pretty dwarf alpine. Brilliant yellow flowers. 6 in.

Ferforatum. (St. John's Wort.) The European type with a yellow flower. Later blooming

* Reptans. Fine rock plant. Prostrate. Masses of bright yellow. Trailer

HISSOPUS-Oficinalis. Cultivated for medical purposes, and also as an $\mathrm{Or}^{\circ}$ mental border plant. Rose

IBERIS - Sempervirens. (Candytuft)

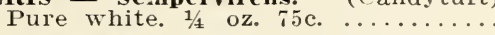

Gibraltarica. Lilac and white. $1 / 4 \mathrm{oz}$ enoreana. Smaller and lower growing than Gibralterica. Color a little darker. Easy. 1/4 oz. $40 \mathrm{c} \ldots \ldots \ldots \ldots$.

INCARYILLEA - Delavayii. Rose red spotted yellow. Fine 2 1-2 feet

Grandiflora Brevipes. Brilliant crimson 18 in. $\ldots \ldots \ldots \ldots \ldots \ldots \ldots \ldots \ldots \ldots \ldots \ldots \ldots \ldots \ldots \ldots \ldots \ldots$

INULA-Ensifolia. A good rock plant. Bright yellow flowers. 12 in. . . . . Grandiflora. "Golden Beauty." Very

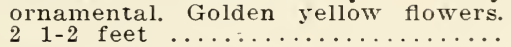

Royleana. Himalayan species. Large rich orange flowers. Splendid border

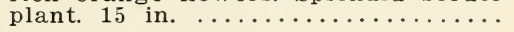

IRIS-Germanica. Large flowered hybrids. Saved from best varieties ....

Kaempferii. (Jap Iris) Wide range of colors in this splendid Iris. 1-2 oz. $50 \mathrm{c} \ldots \ldots \ldots \ldots \ldots \ldots \ldots \ldots \ldots \ldots \ldots \ldots \ldots \ldots$

* Pumila Hybrids. Beautiful dwarf iris. A good rock garden plant. 4 in. ....

ISATIS-Glauca. One of the finest plants for the back border. Masses of yellow flowers. 3 feet.

IXILORION-T'artaricum. Bulbous lilylike plant from western Asia. Dark blue.

10.2

.15 .35

.25 .70

*JASIONE Perenuis. Miniature blue Scabious like heads, neat border. 8 in.

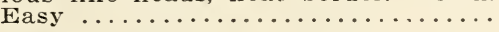

Humilis. Pretty blue heads. Free. New. 12 in. .......................

*ERREIA Saxatilis. Neat rock plant. white. 3 in. ......................

LATHXRCS - Latifolius. (Hardy Sweet Pea). In the following separate col-

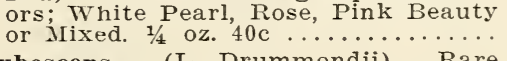

Pubescens. (L. Drummondii) Rare species from Argentine. Pale blue flowers. Climber ...................... 50

Rotnndifolius. Pretty salmon red. Free. .35 .70

*LATENDULA-Veris. True lavender, $1 / 4$ oz. $30 c . \ldots \ldots \ldots \ldots \ldots \ldots \ldots \ldots \ldots \ldots$.

Spica. Dwarf type of the True Laven-

.10 .25 

*LEONTOPODIUM-Alpinus. (Edelweiss)
One of the finest Alpines. Dwarf wooly foliage and white flowers. . . .20 .50

sibiricusn. Large flowered form of

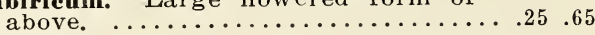

LEWISIA. Finchii. A rare and beautiful Alpine. Large rosettes covered with delightful soft pink flowers. $4 \mathrm{in.}$.

Pygmoea. A dainty rock plant of minature habit. Rare. 3 in. TRIS - Graminifolia. Long showy

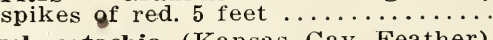

Pychmostachia (Kansas Gay Feather) An excellent back-border perennial. Handsome spikes of rose purple. Fine for cutting. $1 / 4$ oz. $50 \mathrm{c} . \ldots \ldots \ldots$

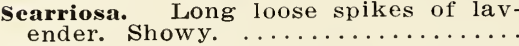
pieata. (Blazing Star). Heavy red

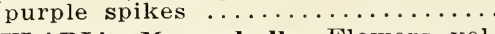

LIGULARIA-Macrophylla. Flowers yellow on long terminal racemes. Fine. .10 .25

\section{LILIUIM}

The seeds presented in the following list have been collected in the three sections of the world where lily seed is most extensively grown-the Iakes region, the Pacific coast of the United States, and England
These seeds represent the best and hardiest lilies under cultivation.

Regale-Our stock of this is taken from bulbs that are held expressly for seed production, and will give the very best results, both in germination and vitality. We plant in frames in early May. Seed germinaates in about two weeks. Let the ates in about two weeks. Let the the bulbs should be lifed and stored in dry sand in a cool place, free from frost, and then planted out again in May. The second fall lift the bulbs and plant about 3 in. deep in a per-

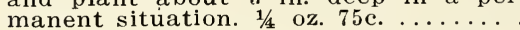

Auratum. (Gold-Band Iily of Japan) This popular lily is easily raised from seed. One of the best. 4 feet.

Giganteum. A wonderfully fine Lily growing as high as seven or eight feet. Long tubular white blooms.

Henryii. A sensational Japanese variety. Brilliant olange yellow flower of perfect form. Hardy and free blooming. Specially collected seed.

Martagon. ('Turk's Cap Lily). Glossy purple flowers, spotted black. Much admired in England. Sow in Fall. 4 feet

Martagon Album... Handsome pyramidal spikes of waxy white reflect ed flowers in July. An attractive Lily.

Martagon Backhouse Hybrids. A fine hybrid. Many shades of light pink

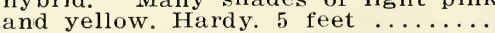

Pardalinum. Bright orange-scarlet flowers. A handsome and easily grown variety. 4 feet ..............

Sulphur-Gale Hybrias. Beautiful flowers of colors ranging white to sulphur with chocolate red markings on the back of the petals. 4 feet. .

*'Tenuifolium. A charming dwarf lily from Siberia. Colal red flowers. A striking addition to the rock garden. 15 inch

Washiugtomianum. A distinct Species. A magnificent item from the Pacific Coast. The colors of light and winered blend beautifully. Handle much the same as L. Regale, $31-2$ feet

Packet of each of the eleven lilies \$3.00

*IINARIA Alpina. Violet and orange, superb rock plant. Trailer .......
Alpina Rosea. Rosy purple and orange Alpina

* Anticaria. Alpine species. Large yellow flowers. Good rock plant. 6 in.
Dalmatica. Golden yellow flower... PktPkt

*Hendersonii. Splendid purple, dwarf growing ..................10.25

*LINUM-Perennae (Hardy Flax). Blue white or mixed. $1 / 4$ oz. $25 \mathrm{c}, 1$ oz. $50 \mathrm{c} .05 \quad .15$

Flavum. Yellow flax. ............10 .25

Alpinum. Beautiful Alpine. Grey-blue flowers. Trailer. Good rock plant . . .25 .65

Capitatum. Distinct and beautiful. Large flat heads of golden yellow, Early summer. 8 in. ............

Salsoloides. Rare Alpine. Pretty pink flowers. 8 in. .......................

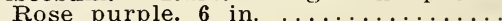

*LIPPIA Repeus. (Sand Verbena) Trailer with pale purple flowers. Useful ground cover for south and mid-

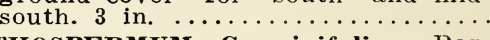

*LITHOSPERMUM-Graminifolium. Rare and beautiful Alpine. Flowers sky-

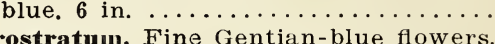
Excellent rock plant. Seeds very

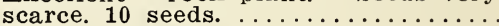

LOBELIA-Cardinalis. One of the most brilliant $r \in d s$ of any perennial. Fine.

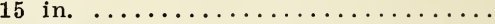

Syphilitica. Large blue flowers. As L. Cardinals, a native of North Ameri-

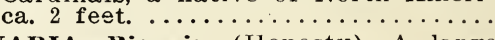

LUNARIA-Biennis. (Honesty). A large flowered showy plant. White, crim-
son, purple, and mixed. 2 1-2 feet. $1-2$

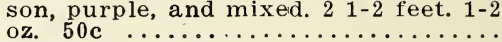

LUPINUS-Arboreus. (Tree Lupine) Fine tall plant. Sulphur yellow flowers.

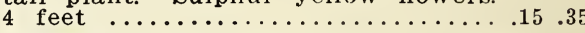

Arboreus Albus. White form of above. .15 .35

Arboreus Paynei. Fragrant flowers of shades of blue, lavender, pink, purple, and white. Silvery grey foliage. A

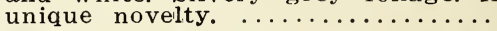

Douglasil. Long spikes of purple, rose and blue. $1 / 4$ oz. $35 \mathrm{c} \ldots \ldots \ldots \ldots \ldots \ldots .10 .25$

Downer's Hybrids. A fine range of colors. A splendid hybrid. $1 / 4 \mathrm{Oz} .30$.

Elliott's sweet scented. Handsome spikes of fragrant flowers. Fine ..

Eveming Glow. Spikes of rose and

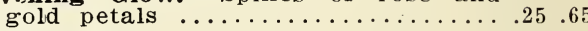

Golden Spire. Attractive purple and

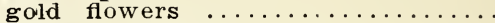

Harkness Hybrids. Wonderful shades of rose, buff, terracotta, mauve and

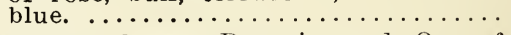

Lavender Qucen. Rare in seed. One of the most charming Iupines .......

Moerheimi. A free Howering rose color ed lupine. Compact liabit and a fine border plant.

Princess Juliana. Clear bright pink.

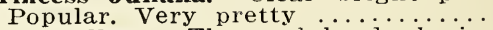

Polyphyllus. The real hardy lupine. Graceful habit. Blue, white and $\mathrm{mix}$

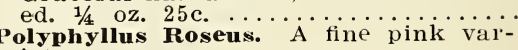
iety . … Alpina. Neat rock plant Dwarf red purple. 3 in. .................... Drkwrightio. An excellent noveity in various shades of yellow, pink and

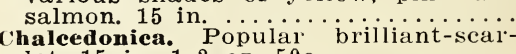
let. 15 in. $1-2$ oz. $50 \mathrm{c}$. $\ldots \ldots \ldots$ flowering Chalcedonica Alba ${ }^{2}$ White flowering form of above. $1 / 4$ oz. Chalcedoniea Salmon Queen. A dis-
tinct novelty. Salmon pink flowers. tinct novelty. Salmon pink flower. Flos-Cueuli. A pretty border plant.

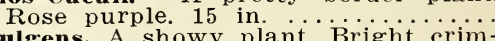
Fulgens. A showy plant. Bright crimson. 12 in. ................... Haageana Hybrids. A fine range of salmon and orange colors. 12 in. $1 / 4$ (The three preceeding varieties when treated as annuals make excellent bedding plants.) 
*Lagascae. Remarkable dwarf evergreen Alpine with rose purple flow

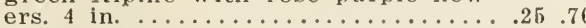

Seiboldii. Largest flowered white ... .15 .35

Visearia splendens. Deep red, early flowering border plant. 12 in. $1 / 4$ oz $35 \mathrm{c} \quad \ldots \ldots \ldots \ldots \ldots \ldots \ldots \ldots \ldots \ldots \ldots \ldots \ldots$ (Musk

MAIVA - Mosehata. (Musle Mallow) White, rose or mixed............. A double white edging plant. Attractive. Free

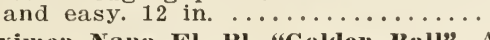

Eximea Nana Fl. Pl. "Golden Ball". A divarf golden yellow border plant. Forms a mass of bloom. 10 in. ....

Eximea Nana Fl. Pl. "Snow Ball."
Pure white form of above. Especially Pure white form of above. Especially

M A'THIOLA-Bicoruis. (Night Scented Stock). Biennial. Reddish lilac only

MECONOPSIS-Baileyi. One of the finest introductions of recent years. A glorious slky-blue poppy from Thibet. It is liardy, and should rank as one of the most popular perennials. Sea-

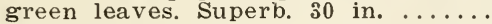

Cambrica (True Welsh Poppy). Lovely shade of yellow. $12^{\prime \prime} \ldots \ldots \ldots \ldots$. . . .

Integrifolia. A wonderful $\mathrm{Ch}$ i n e se poppy. Bright primrose flowers of large size. New. 3 feet. ..............

Pratti. Flowers of a delicate shade of blue. Biennial. $18^{\prime \prime} \ldots \ldots \ldots \ldots \ldots \ldots$ Wallichi. Remarkable poppy from Himalayan mountains. Clear shade of
blue. Start seed in cool protected

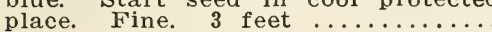

MERTENSIA - Virginica. (Blue Bells) Fine native. Pale blue flowers, and attractive glaucous foliage. $18^{\prime \prime}$....

MIMULUS-Cardinalis. Scarlet flowers. $15^{\prime \prime} \ldots \ldots \ldots \ldots \ldots \ldots \ldots \ldots \ldots \ldots \ldots \ldots \ldots$ mo Dwarf habit. Yellow flowers. 9 in. Orange Perfection. A delightful shade of bright orange. La $\mathrm{r}$ g e flowered.

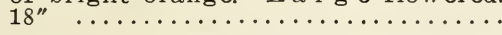

MONARDA - Didyma. Cambridge Scarlet (Bergamot) Scarlet flowers with delightfully fragrant foliage. 1.2" ...

MON'TBRETIA - Crocosmiflora. Beautiful orange colored spike. A bulb. No

MORINA - Longifolia. Elegant white flowers changing to purple. Deco-

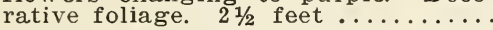

MYOSOTIDEUM-Noble. The wonderful New Zealand giant forget-me-not. Flowers deep blic, edged white. Sow in heat, plant out in partial shade.

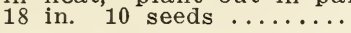

*MYOSO'TIS- (Forget-Me-Not)

Alpestris Distriction. Early and everblooming. $1 / 4$ oz. $40 \mathrm{c} \ldots \ldots \ldots \ldots \ldots .10 .25$

Alpestris. Deep blue. $1 / 4$ oz. $35 \mathrm{c} \ldots \ldots .10 .25$

Rosea. Rose colored form of the above. 1/4 oz. White form of the above. $1 / 4$ oz. llba. White form of the above. $1 / 4 \mathrm{oz}$ ndigo. "Dark blue form of above. oz. $35 \mathrm{c} \ldots \ldots \ldots \ldots \ldots \ldots \ldots \ldots \ldots \ldots \ldots$ Hybrida Ruth Fischer. A charming bril

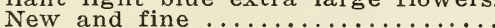
obusta Grandifiora. $\mathrm{E}$ Fonrobert Large flowered blue. $1 / 4$ oz. $60 \mathrm{c} \ldots$
alustris Semperflorens. blooming, blue. The best border my -

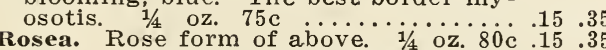

stricta. An alpine Forget-Me-Not with large flowers. Especially fine for
bedding. White, Sky-Blue, Rose, or bedding. White, Sky-Blue, Rose, or 10.25 Mixed .......... Perhaps the tallest myoso-

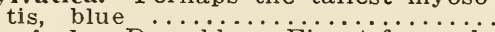
Rupicola. Deep blie. Finest for rock-

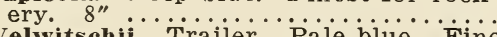
Velwitschii. Trailer. Pale blue. Fine
MYRIHIS - Odorata. (Sweet Ciecly) White plowers, finely cut, pragrant foliag’e. $30^{\prime \prime} \quad \ldots \ldots \ldots \ldots \ldots \ldots \ldots \ldots \ldots$ mint. $\Lambda$ valuable everblooming dwarf border or rock plant. Blue

Wilsonii. Spikes of purple flowers. 18" .25 .65

*olenóthia - (Fve n i g Primrose) Youngii. Orange, persistent bloomer. Fine for shade

Drummondii. Medium dwarf yellow .. .10 .25

Lamarekiana. L a $\mathrm{rg}$ e flowered, tall yellow. $1 / 4$ oz. $35 \mathrm{c}$

Missouriensis. Largest flowered, pale yellow

Speciosa. More slender than the type and taller. White, rose or mixed

Clutei. A handsome plant native of Arizona which has become increasingly popular. Clear bright yellow flowers on four foot stems

ONONIS - Natrix, Low, much branched perennial. Flowers yellow, tinged

ONOPORDON-(Cotton Thistle) Bracteatum. Large silver leaved spiky foliage, purple red flowers. Scotch This tle, 5-7 ft.

alteri. The best ornamental thistle 10

*ONOSMA - Stellulatum. (Golden Drop) Charming little rock plant. Pale yellow flowers. $6^{\prime \prime} \ldots \ldots \ldots \ldots \ldots \ldots$

OROBUS-Montanus Aurantiacus. First class border plant." Bright deep orange flowers. $18 " \ldots \ldots \ldots \ldots \ldots \ldots$

Niger. Reddish purple flowers. Neat.

\section{PANSY}

The producing of Pansy seed is becoming more and more specialized. Realizing this, we have procured the best that is grown in Europe and Oregon, and we highly recommend the varieties listed below. IVe feel confident they will be entirely satisfactory, giving extra large flowers of marvelous hues.

For Spring bloorning sow in mid-August in cold frames. Transplant to three inches each way. and give slight protection through the winter Within the past two years plants from our Pansy seed have won prizes in different parts of the world. Our special Oregon Pansies took prizes in Australia at the leading shows, and in this country we have been successful in scoring victories at important flower shows.

oregon Giants. (Ellis) This famous strain of Pansies is unquestionably the finest mixture of quality Pansies that is produced. Striking and unusual colors and blooms of extra large size. Origirator's stock

American Perfection. An Oregon grown Pansy that is a delightful mixture of fine colors with large well shaped blooms. $1-8$ oz. $\$ 1.50$

swiss Giants, (Roggli Giants). This fine variety is the result of years of careful breeding. Immense flat flowers in a mixture that shows an excellent range of new and 1 are colors, salmons, pinks and reds. $1 / 8 \mathrm{oz}$ $\$ 2.00$

Roggli Lake of Thum. A solid blue pansy with dark blue blotches. Immense size and of fiñe substance. Extra

Rogrgli Cardinal Shades. Extra selected cardinal shades of this cxcellent new carainal shades of this

Giant Exhibition Mixed. A choice mixture of the best of Holland grown stock. A wide color variation and blooms of large size. 1-8 oz. $\$ 1.25 \ldots$

Non Plus Ultra. A large flowered type with a pleasing mixture of colors. One of the best for quantity sowing ing. $1 / 4$ oz. $\$ 1.00 \ldots \ldots \ldots \ldots \ldots \ldots$ 
Special Florists strain. A fine mixture for those who grow for the market. $1 / 4$ oz. $\$ 1.75 \ldots \ldots \ldots \ldots \ldots \ldots \ldots \ldots$

Finest Bedding Type Mixed. For a colorful bed, this Pansy is fine. blooms. 1 oz. $\$ 1.25 \ldots \ldots \ldots \ldots \ldots$

Extra Giant Goldeu Gate. Golden yellow blotched. Fine for forcing. 1000
seeds $\$ 1.00 . \ldots \ldots \ldots \ldots \ldots \ldots \ldots \ldots \ldots \ldots$

Extra Giant Mereury. Black purple, prettily ruffled. 1000 seeds $\$ 1.00 \ldots$.

Extra Giant Minerva. Rutilled Mahogany red. 1000 seeds $\$ 1.00 \ldots \ldots \ldots$

Extra Giant Cardinal. Brilliant scarExtra Giant Mauve Queen. A delicate mauve. 1000 seeds $\$ 1.00$

Extra Giant Mastodow. A fine mixture in large faced Pansies. 1000 seeds $\$ 1.50$

Orchidae flowered Iixed. A bright mixture of light colors. ................. Cassier's Chesnut Brown. Yellow with assier's Hortensia Rose. Five blotched delicate rose. $1-8$ oz. $.50 \mathrm{c} \ldots . . . .$.

Trimardeau Mixed. Thin petaled type in a good color range. Flowers ax large and run to light shades. $1 / 4 \mathrm{oz}$

Trimardeau st. Knud. A fine large flowered lrilliant orange ...........

PANSY New Larly Flowering (Hiemalis) Earliest to bloom. They produce a fine displ:ty of color, and are especially fine for bedding. Sown in the autumn, they will show an abur dance of bloom in early

Celestial Queen. Sky

Helios. Pure yellow.

Ice King. White with dark blote
Jupiter. Clear blue and purple.

Iars. Porcelain blue.

Iarch Beauty. Brilliant purple.

North Pole. Snow white.

North Pole. Sure white.

Wodan. Dark purple almost black.

wintersun. Golden yellow, dark spots.

Mixed. Mixture of named varieties. Any of above pkt. $10 \mathrm{c}, 1-8$ oz. $25 \mathrm{c}$ $1 / 1$ oz. $40 \mathrm{c} ; 1-2$ oz. $75 \mathrm{c}$.

One packet of each of the ten colors, 75e.

\section{PAPAVER}

Hybrid poppies will not come true from seeds, though most carefully segregated. They will, liowever, show upward of 50 per cent of the parent shades. Our plants as offered are grown from root cuttings and are 100 per cent true.

PAPAVER ORIENTALE - Bracteatum. Bright orange scarlet with distinct black spots in center of inner petals. .10 .25

Beauty of Livermore. Fine shade of

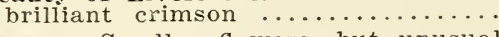

Mauve. Smaller flowers, but unusual color. Fire ...................... A fine salmon with dark

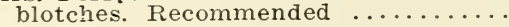

Orientale. The popular orange scarlet poppy. $1 / 1$ oz. $25 c . \ldots \ldots \ldots \ldots \ldots \ldots \ldots$

Perry's White. The best white poppy. others. Worth trying

Royal scarlet. One of the largest brilliant reds. Flowers are a vivid scarlet.

Salmon Queen. Wonderful shades of salmon pink ... Peolicate shell pink

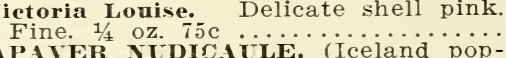

* P PA VER NUDICA ULE. (Iceland poppies). Charming nod or mixed. $1 / 4$ oz. $40 \mathrm{c} \ldots \ldots \ldots \ldots$ Giant Tangerine. Large russet orange

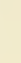

Double Mixed. A fine range of colors in the doubles. ...................... tints. Large flowered. Extra .....

El Monte. New. Enormous sized blossom of a vivid orange tangerine color. Long graceful stens which makes it fine for cutting. Easily grown and comes true from seed.

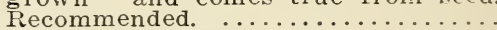

* PAPATER ALPINUM. Lovely dwarf variety of mixed colors. Ideal for rock garden. Glaucous little rosettes. Place in cool situation. 6 in. ............

PAPATER PILOSUM. Border plant of easy growth. Shades of salmon pink.

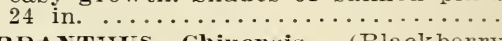

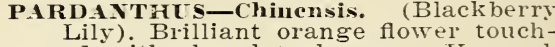
Lily). Brilliant orange flower touch-
ed with chocolate brown. Unusual.

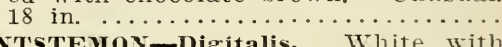

PENTSTEMOY-Digitalis. White wit purple throat. ................... Fine novelty Long spikes of purple and lavender:

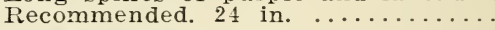

Hartwegii. Scotch prize strain. Excellent beading plant. Large flowers mixed colors, will bloom first season if sown early. 15 in. . . . . . . . . .

Hartwegii Albus. The first pure white bedding pentstemon. A valuable new variety. 24 in. ..................... Pubescens. Neat border plant.
flowers tinted violet and flesh. 15 in Riehardsonii. Unúsual shade of color. Purple with a red tint. 18 in. .....

'Torreyii. Tall rea flowers. Brilliant color. 3 1-2 feet ......................

Torreyii "Coral Gem." Taken from our own plants. A bright shade of pink.

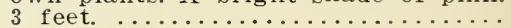

Torreyii "Shell Pink. One of the most delicate shades of pink. A charming and graceful border plant. Highly recommended. 2 1-2 feet.......

PEONY-Chinensis. Taken from a splendid collection. Worth trying ........

PHLOX-Decussata. Taken from our named varieties. These will give you many fine seedlings. All new origins come from seeds. $1 / 4$ oz. $75 \mathrm{c} . . . . . .$.

Decussata "Selected Blues". Taken from the best varieties. Recommended $\ldots \ldots \ldots \ldots . \ldots \ldots \ldots \ldots \ldots \ldots \ldots \ldots$. $\ldots \ldots$. from the best crimson varieties. Rec-

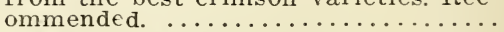

Decussata. "Selected Pinks." Taken from the best pink varieties. Recom-

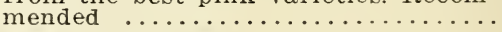

PHYSALIS-Franchetti. Chinese lantern plant. Bright red in Fall ..........

Bunyardii. Elegant and striking hy-

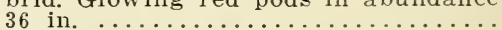

PHYSosteGIA-Virginica. (False Dragon Head) Spikes of clear pink. Tery pretty and easy. 18 in. $1 / 4,0 z .35 \mathrm{c} \ldots$.

virginica Alba. Pure white flowers

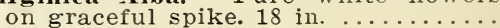

* PHYTEUMA-Scheuchzeri. Dark blue

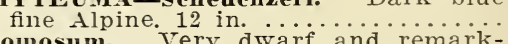

Comosum. Very dwarf and remarkable form. Pale blue. One of the

Harest Alpine gems. 3 in Neale Alpine with

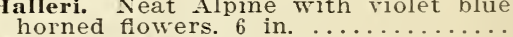
PLATYCODON- (Balloon Flower)
Grandiflorum.
or mixed. 18 in. $1 / 4$ oz. $50 \mathrm{c} \ldots \ldots . . . .$. Grandiflorum. D.ouble mixed. 18 in. . . $.10 \quad .250$

* Iaresii. Dwarf form, Blue, white or

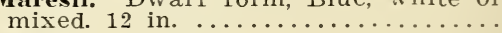

PLCMBAGO. Larpentae. This is the first time we have ever listed seed of this charming Fall blooming border plant with its attractive cobalt-blue flowers. Recommended. 

lewn. BIne. 1/40\%. $30 \mathrm{c} \ldots \ldots \ldots \ldots \ldots \ldots .10 .25$ Aloum. White form, 14 $0 \% 30 \mathrm{c} \ldots \ldots .10 .25$ Richarasonii. $1 / 4$ oz. $50 \mathrm{C} \ldots \ldots \ldots \ldots \ldots \ldots .15 .35$ Himalayienu. Larger flower than Cocruleum. 1/4 oz. $50 \mathrm{c} \ldots \ldots \ldots \ldots \ldots .15 .35$

Humile. A very pretty, easy Alpine

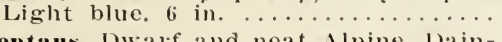

Reptans. Dwarf and neat Alpine. lainty blue flowers. $6 \mathrm{in} . \ldots \ldots \ldots \ldots \ldots$. with ormamental foliage ...........

Viviparum. Dwarl species. Rosy pink Howers. 6 in.

PO'YEN'TILLA--A t rosanguinea. (Cinquefoil). Deep blood-red flowers. 15 in. 10.25

Hybrida "Firefl:ume." Mass of fiery-

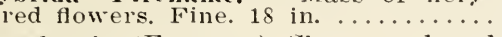

Nepalensis (Formosa) Cherry red and buff flowers, pretty 24 in. ..........

foliage. Delicate pink flowers. 2 in. .25 .70

\section{PRIMULA}

This list of primulas has been selected by an English garden expert as the best and most representative types of hardy primulas. Many of these varieties are imported direct from England, and we present them to you, confident that you will find each item the best of its type.

Auricula. Charming mixture for borders. Large flowers. 6 in. ..........

Beesiana. Bright velvety purple flow-
ers with yellow eve. Fine novelty. ers with yellow eye. Fine novelty. 24 in.

Barr's Exhibition Reds. Finest strain of polyonthus in crimson shades.

Barr's Iunstead Giants. A fine poly anthus mixture in white, golden or

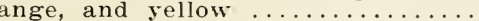

Bulleyana. Rich apricot in long spikes.

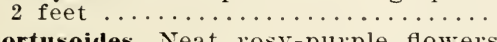

ortusoides. Neat rosy-purple flowers.

Farinosa. Dwarf pale purple. Pretty

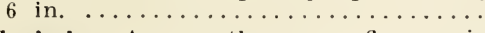

Florindae. Among the many fine varieties which Captain Kingdon Ward brought out of Central Asia this gigantic primro:e stands as one of the most unusual. Rising four feet above the ground it bears 50 to 70 fragrant bright yellow pendant flowers. Has proven to be as hardy and rigorous here as in its native Thibet. Recommended ............. Recommended $\ldots \ldots \ldots \ldots \ldots \ldots \ldots \ldots \ldots$

tion of light scarlet flowers. 15 in ..

Hybrida Ipswieh. A marvelous strain containing many shades of scarlet, orange and mauve. 24 in. ............

Hybrida Lissadell. Beautitul soft vermilion flowers. 24 in. ............ crimson. Intense fiery-red. 24 in. .

Japonica. A fine Primrose for the border. Stands about 18 inches high with very pretty flowers of mixed shades. Iostly crimson, rose, and white...

Littoniana. Fine novelty from China Slender spikes with crinson buds and mauve flowers. Striling and rare

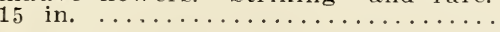

Moerheimi Hybrids. Large flowers on stiff stems. Color ranges from red, orange, to light pink. Tery distinct

Poissoni. Fine Chinese species. Deep purple spikes. 12 in. .............

Pulverulenta. A vigorous grower. Spikes of crimson and orange. 24 in. .15 .35

Pulverulenta Bartley strain. This will give many seedling's with colors varying. Rose, light pink, coral pink and blush predominate. Beautiful. Recommended.

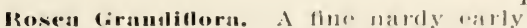

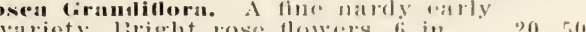
uneolenx. The native (e)wsip. Fin. for naturalizing. Yollow flowers on nine inch spikes

suaveolens rovera choice. (Ciant ('o) slips). Selected from giant crimson, scarlet, orange and yellow. leree blooming and vigoreus. (ireatly ardmired. 15 in.

Veitehii. A fine primula in purple shades. $12 \mathrm{in}$.

Veris. The popular polyanthus. A splendid mixture of white, led orange, and golden yellow. For quan tity sowing. 8 in. $1 / 4$ oz. $40 \mathrm{C}$

Veris in colors. Separate color's, orange, red or white. $1 / 4$ oz. $75 \mathrm{c}$

Veris coerulea. Interesting and beautiful. Saved from the best shades of delicate blue. Recommended. 6 in.

Veris "Gold-Laced" sared flom finest varieties. Fine range of colors. 12 in.

Iulgaris. The true yellow primiose. Ideal for rock garden. 4 in. ...........

PIRUNELLA- Gramdillora. Attractive dwarf Alpine. Deep violet blue. 8 in. .15 .35

PYRE'THRI I-Roseum Hybridum. Good color range, carefully selected on our grounds. $1 / 4$ oz. $35 \mathrm{c}$

Atrosanguineum. Red shades in mixture. $1 / 4$ oz. $75 \mathrm{c} . \ldots \ldots \ldots \ldots \ldots \ldots \ldots \ldots \ldots$

Carueum. Pink shades in mixture. 1/4 oz. $75 \mathrm{c}$

James Kelway. Giant flowered bright crimson. Larger plant, larger seed. $1-8$ oz. $90 \mathrm{c}$

Langport Scarlet. A magnificent vermillion single. Extra large. Trill not come $100 \%$ true but many will show this splendid new introduction. Re-

Best Doubles in Mixture. Taken from flowers unequaled. Round as a ball, fine color range. Should show 60 pel cent double. ....

Note, the doubles will not show over 60 per cent double. Do not make selection until the second season of bloom. First bloom is not typical, and will show upward of 95 per. cent single.

*RIMONIIA-Pyrenaica. (Fosette MI lein.) Oiten called Alpine Violet. Requires protection. Fine pot plant for the house. Very hard to grow

*RANUNCLLUS-Isiaticus. The best of the Asiatic or bulbous Ranunculus

Glacialis. Choice Alpine. White flowers. 6 in.

RONNEYEA-Coulteril. (Poppy Mallow) Large white poppy-like flowers. 3 ft. .10 .25

ROSMARIUS - Oricinalis. (Rosemary) Semi-shrub which blooms early in Semi-s
spring

IUDBECIIA - Fulsida (Cone Flower) Brilliant orange yellow. $1 / 4$ oz. $45 \mathrm{c}$.

Hybrida Grandiflora. Large flowered golden orange. $1 / 4$ oz. $45 \mathrm{c}$

* Newmanii. Orange yellow, black cen ter. $1-8$ oz. $35 \mathrm{c}$

Purpurea (Giant Purple Cone Flower) ${ }_{1 / 4}$ oz. $40 \mathrm{c} \ldots \ldots \ldots \ldots \ldots \ldots \ldots \ldots \ldots \ldots \ldots \ldots \ldots$ yel

RUTA-Graveolens. (Rue) Fragrant y

10.25 low flower which blossoms in July.

RYDRERGIA Grandifiora. (Described by Dr. Brand who collected this seed.) A beautiful composite about six stony meadows of the Colorado Rockies. Its large yellow rayed flowers with gray green leaves makes an arresting picture. Easy from seed.

SALVIA - Irgentea. White flowers, large ornamental silver foliage. 24 in. large ornamental silver fodage. Blue.

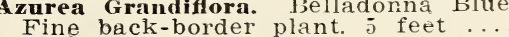
Fine back-border plant. 5 feet $\ldots . .$.
Farinacea. Long spikes of light blue. Fine. Alust be protected. 30 in. 
Globosa. Ornamental. Silver foliage, White flowers, Easy. 36 in. ......10 .25

Nutans. Dark blue drooping flowers.

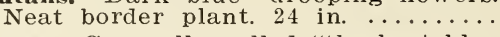

Patens. Generally called "the best blue in the floral lingdom." Fine. 24 in. . .

Pratensis. Useful border plant. Violet blue, free blooming. 30 in. ..............

Ringens. Spikes of reddish purple. ... .15 .35

sclarea. Flowers blue and white. Attractive wooly foliage. 3 feet. .....

Turkestanica. Alba. This has very ornamental foliage. Flowers are somewhat insignificant, but the plant is striking. $1 / 4$ oz. $35 \mathrm{c} . \ldots \ldots \ldots \ldots \ldots$

Turkestanica Rubra. Easy and free. Forms an attractive plant because of its foliage. The flowers are red tinged pink. $1 / 4$ oz. $35 \mathrm{c}$

Vaticau. A type of S. Turkestanica but the flowers are a delicate mauve, and the foliage is more graceful. Extra

SANGUINARIA Canadensis. (Bloodroot) Pretty American native. Glaucous kidney shaped leaves, white star-like flowers in the spring. 6 in. .2

SAPONARIA-Bellidifolia. Choice little alpine. Bright red flowers. Dwarf. .

Caespitosa. Neat clusters of rose flowers. Fine for the rockery. 9 in. ....

ocymoides. This fine perennial is ing from walls. Light rose color.

ocymoides alba. Clear white form of

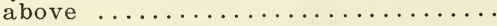

SAXIFRAGA-Megasea Hybrids. Large flowered mixed

Cordifolia. Large leaf flowers rose. The hardiest saxifrage

Decipiens Grandiflora. Masses of charming white flowers that rise a foot above a compact rosette. Foliage

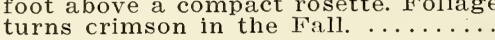

Longifolia. Queen of the saxifrages. Handsome rosettes of long leaves. White flowers. 20 in.

Stribrnyi. Silver rosettes, purple flow ers, with red bracts and stems .............

SCABIOSA-Caucasica. A very attractive and satisfactory border plant. Excellent for cutting. Clear blue. $1 / 4 \mathrm{oz}$. $75 \mathrm{c}$.

Caucasica Alba $T h i s$ is an ideal companion for the blue scabiosa. Very pretty. Well formed flowers. $1 / 4$ oz. $\$ 1.00$

Caucasica "IBlue Beauty." Reselected. Very double, lavender blue flowers, extra large. A new, and highly recommended variety

Caucasica "Perfecta". An improved Caucasica. Flowers vary in color from lavender pink to blue. Fine. 1/4 oz. $\$ 1.25$

Issac House New Hybrids. A fine strain of extra large flowered blue shades. Beautiful doubles

Colunbaria Rosea. A valuable new pink scabiosa. Very pleasing for the border. Recommended. 24 in.

Japonica. A dwarf, bright blue. Useful in the rockery. $1 / 4$ oz. $75 \mathrm{c} \ldots \ldots$.

SEDUM-Aere. Miniature tufts of dull green. Small golden flowers. Suited

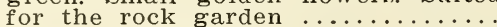

Aizoon. Neat yellow dwarf for the border. 12 in. .................................

Dasyphyllum. Miniature blue gray

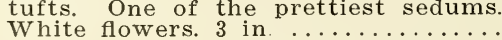
White flowers. 3 in. ............. Short thick leaves on trailing branches. Dense clusters of pink flowers .

Hispanicum. A pretty little dwarf with delicate pink flowers. 2 in. $\cdots$ Trailer with amschaticum. $\quad$ Trailer with bright
Pilosum. The charming waxy-pink Pkt Pkt flowers and its compact growth, the rockery. Recommended. Bienthe rockery. Recommended. Bien-

Rupestre. Miniature globes of blue grey that are especially attractive.

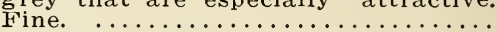

Spuriunx Coceineum. A late bloomer. Reddish purple. Splendid for border.

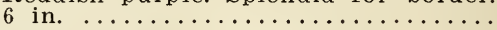

SEMPER VIVUM-Arachnoideuna. (Cobwebbed Hen and Chickens). Pretty compact rosettes with a covering much like a cobweb. Desirable in the

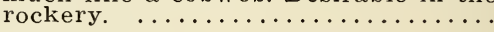

Schotri. Ruby tinted rosettes. A fine variety $\ldots \ldots \ldots \ldots \ldots \ldots \ldots \ldots \ldots .25 .70$

Triste. Leaves bronze and green. A very symmetrical rosette. Recom-

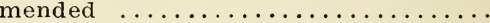

Mixed. (Hen and Chickens). Fine mixture of strong growing varieties .. .15 .40

SENICIO-Clivorum. Heavy growing perennial with heads of yellow flowers,

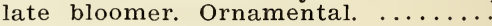

Clivorum Orange Queen. Splendid border plant with a brilliant shade of

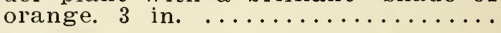

Subcrenatus. Lower growing, larger flower $\ldots \ldots \ldots \ldots \ldots \ldots \ldots \ldots \ldots \ldots \ldots$.

Veitchianus. Fine for specimen planting. Wide spreading tuft of large $3 \mathrm{ft}$. with yellow flowers along the upper two feet. Very easy and hardy .25 .65

Incauus. Alpine. White foliage, yellow flowers. 6 in. ............ $20 \quad 50$

*SHAMROCK - (The True Shamrock of Ireland.) $1 / 4$ oz. $75 \mathrm{c} \ldots \ldots \ldots \ldots \ldots \ldots .15 .35$

SIDALCEA-Candida. A tall white flowering plant. Fine for waterside. Sow

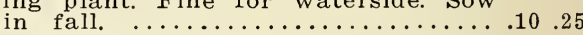

Rose Queen. Pretty rose colored form

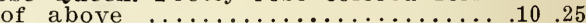

Rosy Gem. A lower growing plant with pretty mallow rose colored flowers.

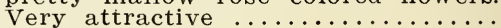

Hybrida. New and fine. This strain contains all colors of pinl, rose, red, salmon, lilac, and heliotrope. 30 in .20 .50

SILENE-Asterias Grandiflora (Catch

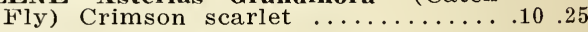
Orientalis Compacta. Compact, deep

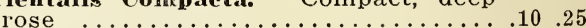

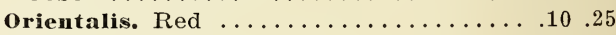

Saxifraga. Long flowering, white ... .10 .25

Acaulis (Moss Campion) Dwarf tufts.

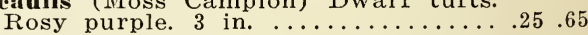

Sohafta. A very pretty trailer. Rosy purple. Splendid for the rock garden $\ldots \ldots \ldots \ldots \ldots \ldots \ldots \ldots \ldots \ldots \ldots \ldots \ldots \ldots \ldots \ldots \ldots$

SISYRINCHIUM-Bermudiauna. Dwarf grassy leaved plant with bright blue

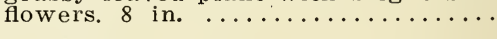

SOLDANELLA. Alpina. Elegant dwarf alpine. Drooping flowers of porcelain

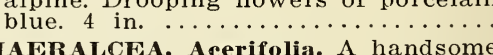

SPHAERALCEA. Acerifolia. A handsome quick growing perennial from Oregon. 30 inch spikes covered with pale rose blossoms. Received an Award of Merit by the R. H. S. De-

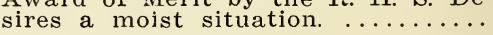

PIREA-Filipendula. Finely cut fol-
iage white heads on $2 \mathrm{ft}$. stems. Very

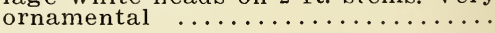

* Ulimaria. (Queen of the Meadows)

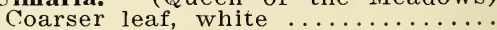

Astilbe Hybrida. Hybrids of gorgeous shades in this fine variety ...........

Aruncus. A hybrid resembling Astilbe.

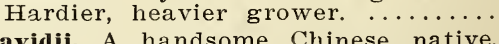

Davidii. A handsome Chinese native Flowers rose violet in large plumes. 48 in shady places most suitable. 

*S'TCilys-Ianata (Rabbit's Ear) Thiek

Alpina. Deep rose, dwarf ......................

Coccinmea. Long spikes of searlet flow

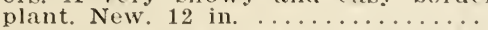

S'I'TICL-Iantifolia. (Sea l avender). Excellent for cutting. Malies fine winter bouquet. $\Lambda$ mass of small delicate flowers, 20 in. $1 / 4$ oz. $50 \mathrm{c} \ldots$.

Caspia. Delicate and artistie everlasting. It is as hardy as the latifolia type and makes an earlier cut with more sprays. A fine filler and especially pretty in the border. ......

Eximea. Dwarf. Color ranges from li

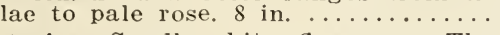

Tatariea. Small white flowers. The best for dyeins. 18 in. ................

S'TOKLSIA - Cyanca. (Stoke's Aster) Fine border plant. Blooms all sum 12 in. In lavender-blue, white or mixed. $1 / 4$ oz. $50 \mathrm{c}$

STYLOPHORUM. Diphyllum. (Celandine Poppy). Fine poppy-like flowers of a brilliant shade of orange. Excellent

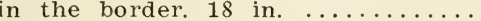

WHALICTRLM - Adiantifolium. Fernlike foliage, white flowers ..........

Aquilegiafolium Purpureum. Rose pur-

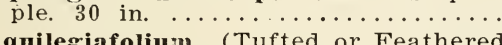
Columbine). Mixed. $1 / 4$ oz. $75 \mathrm{e} . . .$.

Glaucum. With yellow flowers .......

Dipterocarpum. This is one of the handsomest perennials in this entire list. Given a good part shade and fairly heavy soil, it is perfectly hardy. Buds resemble pearls, opening to delicate lavender flowers, with yellow eenters. $1 / 4$ oz. $\$ 1.25$

THERMOPSTS-Caroliniana. A handsome hardy perennial with spiles of
golden yellow. Seeds germinate

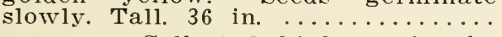

Iontana. Collected high up in the North American Rockies. Large lupin-like spikes of pale yellow. A

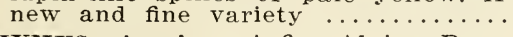

*THYMUS-Azoricus. A fine Alpine. Rosy purple. 2 in. $\ldots \ldots \ldots \ldots \ldots \ldots \ldots \ldots$.

Coccinneus, Bright red, persistent

Nunumularis. A eharming rock plant.

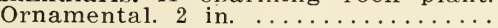

vulgaris. (Common Thvme) ean be used in border or rockwork. An old garden plant used as a sweet herb.

TIAREILA - Cordifolia. A eharming dwarf Ameriean native. Foamy whit spikes in early Spring. Excellent for shady situation in roekery. New

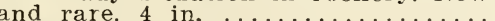

TRI'TOMA (Red Hot Poker)

Express. Mixture of early sorts. 1/4

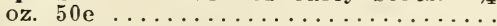
May Flowering Hybrids.

Tuckii. (May Oueen) 1/4 oz. $50 \mathrm{e}$.

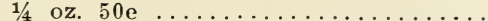

Rufa. Rare and ehoice Long. slende spikes, yellow tipped red. 30 in. .... Tritomas will not come true but the variety named will predominate.

TROLLIUS-Caucasicus. (Orange Globe Flower) Orange globes. 1/4 oz. $\$ 1.00$

Ledebouri. This is one of the best of Trollius. Tallest and largest flowering, latest to bloom

Ledebouri "Golden Queci.," ' New and fine introduction. Award of Merit R H. S. Vigorous three feet plants of an intense orange hue. Extremely free blooming. Another of its qualities is that it germinates quite readities is that it germinates quite readi-
ly when sown in the Syring. Highly recommender

Europeus. (European Globe Flower)

Yellow. $1 / 4$ oz. $50 \mathrm{e} \ldots \ldots \ldots \ldots \ldots \ldots \ldots \ldots .10 .25$

$10 \quad .25$

$15 \quad .35$

$.10 \quad .25$
Cioliatlı.

Carliest of All. One of the flrst to bloom. Atrictive orange vellow llowers. 'Tall and gracefu

Pumilus. An unusual dware novelty olly six inclues higli. light yellow flowers. Ideal in the Rock Gardon. 25

IUII. Taken from best Jarwin types mixed

*'IJNIC:A-Saxifraga. Finely eut leaved dwarf border. Small pink flowers. casy, free, $1 / 4$ oz 350

saxifraga alba. The white form of above. Dainty flowers

Saxifraga Rosea. $\Lambda$ new very pretty Tuniea. Trailer, eovered with delieate pink flowers

VALERIANA - Coccinea. (Valerian) Spikes of Red, Rose, or White. $1 / 4 \mathrm{oz}$ $35 \mathrm{c}$.

ofricinalis (Garden Helitrope). A beautiful, tall, highly fraglant perennial Imported seed. White. 1/4 oz. $60 \mathrm{e}$.

VERBASCUM - Giganteum (Moth Mullein). Silver white foliage. Yellow flowers. Fine for back border. feet $1 / 40 z$

.10 .25

Hybridum Harkness Hybrids. Tall spikes of pure deep yellow. Pretty.

Iybridun Miss ivillmott. Large flow ered. Shades of yellow and white.

Libani. Golden yellow spikes. Attractive $\ldots \ldots \ldots \ldots \ldots \ldots \ldots \ldots \ldots \ldots \ldots \ldots$. plant. Shades include white, pink, salmon, and violet. Graceful spilzes.

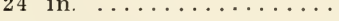

VERBENA-Aubletia Grandiflora. (Rose Vervain). A North Ameriean native Flowers purple tinted rose Not reliably hardy in North, but can be treated as an anrual, making a highly recommended border plant. 18 in

Venosa. This South American Specie is hardy. Its beautiful shade of purple fits ivell into a border. 12 in.

VERONICA - Amethystina. Long spikes of clear blue. Dwarf tufted habit. 12 in.

Backlofeni (Speedwell) Spikes of light blue. 24 in.

Candida. Aconite blue, silvery white

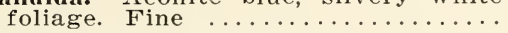

Cataractac. White flowers in profu-

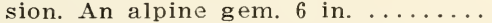

Corymbosa stricta. Dense plume of azure blue. Really fine. 6 in. ....

Guthriana. Excellent dwarf for roekery. Deep blue. 8 in. $\ldots \ldots \ldots \ldots \ldots \ldots$ flowers. For border or roek garden. $1 / 4$ oz. $50 \mathrm{c}$

Longifolia. Spikes of deep blue. Late 20 in. $1 / 4$ oz. $75 \mathrm{e}$

Prostrata. (Hungarian Speedwell) Miniature azure spikes in the spring. An ideal trailer. Fine

10.25

Repens. Forms miniature tufts. Trailer Has pretty delicate white and blue flowers. One of the first to bloom

Royal Blue. Brilliant shade of dark blue. Bushy habit. Fine for roekery. 8 in.

Rupestris. Fine carpet plant. Sheets of brilliant blue in early Spring

Saxatilis. Bright blue flowers. Trailer, fine for rockery

spicata. Flowers of attractive spikes

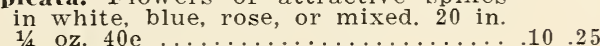




\section{VIOLA}

Cornuta (Tufted pansies). These rarieties are ideal in either the rockery or the border. Nothing gives quite the profusion of bright bloom that these violas do in the spring, and al through the summer.

Admiration. Purple blue. Fine. 1/4 oz.

Boc Perfection. Light blue. is oz. 50 c

Blue Perfection. Light blue. $1 / 4$ oz. $50 \mathrm{c}$
Black Prince. Intense dark purple. $1 / 4$

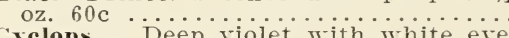
sclops. Deep violet with white eye

llona. New and very pretty. Rich wine red, an unusual and showy color.

Lutea. Chrome yellow. 1/4 oz. $50 \mathrm{c} . \ldots$.
Ianve Queen. Pinkish lavender. $1 / 4 \mathrm{oz}$ Papilio. Biue and white. Pretty ${ }_{1 / 4}$ oz

Primrose Dame. Pale yellow $1 / 4$ oz

70c King. Finest large puiple

Purple King. Finest large purple. 1/4

Rose Queen. Free bloming rose. Fine $1 / 4$ oz. $\$ 1.00$ Dark blue white giound 1/4 oz. $50 \mathrm{c} \ldots \ldots \ldots \ldots \ldots \ldots \ldots \ldots \ldots \ldots$

White Perfection. Large flowered, pure white. Showy. 1/4 oz. $50 \mathrm{c}$.

A Packet of Each of the 'Thirteen Varieties \$1.10 Cornuta "Jersey Gem." This extremely popular item is well deserviug of all its praise. Blooming all summer, it covers the plant with large vivid purple-blue flowers. Its charm lends grace to either the border or rockery. 6 in

Cornuta scotch Borier. Like pansies and almost as large. Good color range. In bloom all summer. $1 / 4$ oz.

scotch Border Extra selected. A magficent strain of the best Tiolas grown in England. A superb mixture of brilliant hues, shared to pastel colors of pink and lavender. The individual flowers are large and perfectly formed. A free and continuous bloomer. Highly recom-

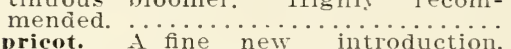

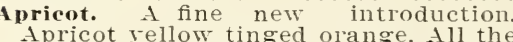
Apricot rellow tinged orange. All the
beautiful shades of Viola "Apricot

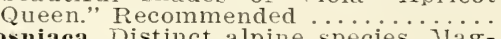

Bosniaca. Distinct alpine species. Mag-

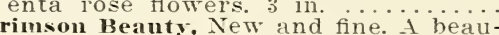
riful bright crimson. Clear and distinct. A charming rock garden ral iety.

G. Wermia. A pretty little variet stems. Tery sturdr and hardy. Pare in seed.

Gracilis. Charming rock species. Rich violet flowers in profusion. Forms a beautiful carpet in May. 6 in. ....... iracilis "Lord Nelson". Pich glowing habit. Fine noveltr

Haslemere. Corered with lilac pink flowers. Tery neat habit. Delightfu norelty. 6 in. . . . Prince of walcs. sweetOorata "Prince of Walcs." Sweet-
scented violet. scented violet. Fragrant. Magnifi
cent blue on long stems. 6 in. Odorata "The Czar." Large dark" blue. Fragrant. One of the best violets for forcing

Odorata Ilba. Tery pretty sweetscented white violet. Fine ...................

*WAHLENBERGIA-Dalmatica. Beauti ful dwarf deep riolet alpine. Not reliably hardy in cold climates, but one of the prettiest for rockery. Rare 6 in.

WALLFLOWER-Single Mixed. 1/4 oz $35 \bar{c}$

Double Yixed. $1 / 4$ oz. $\$ 1.0$

YCCA. Filamentosa. (Spanish Bayonet) A fine evergreen foliage plant with a stately 2 1-2 feet spikes of attractive white flowers. Easy from seed. .15.40

$.25 \quad .70$ 20.50

\section{ORNAMENTAL GRASSES}

Unless stated otherwise these are all hardy perennial grasses.

Pkt Pkt

ANDROPOGON-Argenteus. Silver white beard grass. Fine for drying ....... .15 .35 ARUNDO-Donax (Great Reed) The tallest grass. Requires protection ..... 10.25 CERATochloA - Pendula. Useful for placing in bouquets ....................

ELYMLS - Giganteus. (Giant Bunch

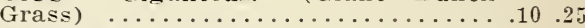

ERIANTHUS-Ravennae, (Ravenna Sugar Grass). Very hardy, tall .....10.25

EILALIA-Japonica. (Japanese Eulalia) One of the most used grasses. Green with white mid-rib ...................... Japonica Zebrina. An attractive tall grass with yellow zebra stripes.

*FESTCA Glauca. (Alpine Bunch
Grass). Neat little tufts of glaucous green. For rockery. Extra. …....... .35

* Alpina. Like above but more on the bluish shade. Fine for border ....... .10.25

Viridis. (Green Fescue) Splendid border .10 .25 ITOELARIA - Setacea. For edging or

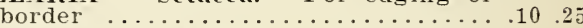

LASIAGRos'is-Argentea. Fine for cutting, green or dry .......................

NELICA-Altissima. (Tall Pearl Grass) .10.25 Altissima Atropurpurca. Tall grass having purplish cast ........ 10 .25

*PAICUM - Virgatum. (Twiggy Panic Grass) Fine for winter bouquets .. .10.2J

Mtissimum. A handsome and useful border plant. One of the best ........ .35

PENIISETIM - Ruppelianum. A fine "drooping" border for tall beds or borders. Much used in parks and public grounds. Not hardy .......... 10.25

Macrourum. (Leng Tailed Pennisetum) This variety is hardy ............. 10.25

* STELLARIA - Graminen Aurea. Not strictly a grass, but with yellow grass-like foliage. White flowers.

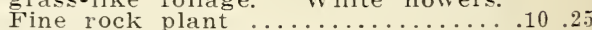

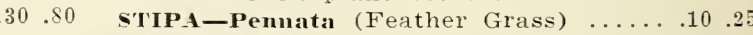

UNIOLA-Latifolia. Large seed heads,

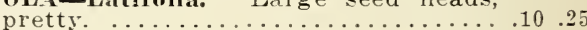

\section{VINES}

As'ARAGLS-Acutifolius. Recommended green for cutting. Requires protection. $1 / 4$ oz. $35 \mathrm{c} \ldots . . . . . . . . .10 .25$

ADLCMIA - Cirrhosa. (Allegheny Tine) Useful clinber, with finely cut leaves. Flower tube shape, flesh color. . . . 10.25

IRIS'TOLOCHIA-(Dutchman's Pipe) ‥10.25 IMPELOPSIS-Veitchii (Boston Ivy) . . .10.25

BIGNONIA-Radicans. ( Trumpet Creeper) .10.25

CLEMATIS-Much used hardy climber, very ornamental.

Integrifolia. Dark blue ............10.25

Paniculata. White, foam like .........10.25

Grandiflora Iixed. A mixture of the large flowered named sorts .... 20.50

Recta. A free blooming fragrant white

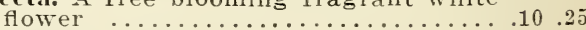

HEDER A - Anglica (English Irs) 1/4 oz. $50 \mathrm{c} \ldots \ldots \ldots \ldots . . .25$ I'UERARIA - Thunbergiana (Kudzu

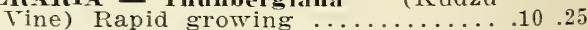

WISTARIA-VIagnifica. Pea shaped lav-

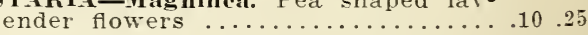

Tine seeds should be stratified, or planted in August to come the next spring.

Te do not carry seeds of Ornamentals, Trees, or Evergreens in stock but will be glad to procure any varieties wanted on request. 


\section{ANNUAL SEEDS}

A NUAL seeds are rapidly becoming more popular cach year as new and more attractive novelties are introduced. The colorful annuals are being used more and more, as bedding plants, as delightful cut flower's, as brilliant additions to the border, and as indespensible fixtures in the alpine and rock gardens.

For thes best results it is important to sow fresh, carefully selected annual seeds-seeds that have been grown under the most favorable conditions.

After many trials and many rigid selections we have observed that some annual seeds srown in California, such as our prize wimning strains of Zinnias and Asters, are far superior to any other strains. We have also observed that certain European grown seed gives the best results. Our entire list has been selected with that thought in mind, and the seed is, in our opinion, the best thai can be procured from both California and Europe.

You will find that all the seed we offer is strictly fresh, true to name, and of a high quality -all important factors in judging high grade seed.

We have listed many varieties especially suited for the rock garden. These bright annuals will give a touch of color, add a brilliance through the summer that cannot be obtained with alpine and hardy herbaceous plants. A list of the rock garden varieties, appearing in the annual section, has been selected for your perusal.

ABronia cubellata. (Sand Terbena). A charming little trailing plant for sunny spots on rock work or hanging baskets, producing heads of fragrant purple-rose flowers with white center

ACROCLINIE Roseum. Very pretty rose tinted everlastings. Double flowered. 12 in. Rose, white, or mixed ...10

* AgERATUM. Decorative little plants for beddings, edgings or pots, blooming from early summer to autumn.

Yexicanum Album $\ldots \ldots \ldots \ldots \ldots \ldots \ldots .10 .25$

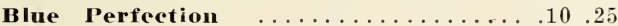

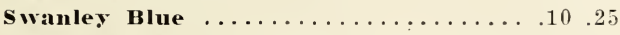

*ALYSSUM (Madwort) Pretty little plant for beds, vases, baskets, edgings or rockery work, bloon:ing profusely all summer; useful also for winter flowering. Tery sweetly scented.

Little Gem. A dwarf white edging plant widely used. 4 to 6 inches. 1

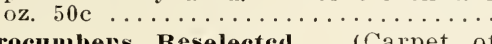
Procumbers Reselected. (Carpet of
Snow). This seelcted strain forms compact, dwarf tufts of even growth. Wonderfully free blooming. A recommended item for a neat border. 1/4 oz. $35 \mathrm{c} ; 1$ oz. $\$ 1.00$

Lilacinum. Dwarf compact variety producing a mass of pretty blushlilac flowers 1 oz. $\$ 1.00 \ldots \ldots \ldots \ldots$

MARANTHUS. Annuals with brilliant foliage and stems. They do best in full sun. sandy or poor soil.

Caudatus. (Love-lies-bleeding). Dark red, effective. $1 / 4$ oz. $25 \mathrm{c} \ldots \ldots \ldots \ldots \ldots$

Caudatus Viridus. Bright green foliage. $1 / 4$ oz. $25 \mathrm{c} \ldots \ldots \ldots \ldots \ldots \ldots \ldots$ Foliage shaded with red, yellow, and green. $1 / 4$ oz. $30 \mathrm{c} \ldots \ldots \ldots \ldots \ldots$

Sunrise. A showy glowing crimson.

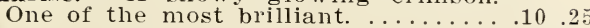

Mixed. A fine mixture ............. 10.20

AMMOBIUM Alatum Grandifiorum. Florets golden yellow, surrounded by silvery white. Everlasting ........10 .25

ANCHUSA. Capensis. Neat dwarf species with small bright blue flowers. 18 in. .10 .25

* A A GALLIS. (Pimpernel)-Mixed Varieties. Extremely showy flowers of the primrose type in various shades of blue and bright red. Good for the rock garden. 6 in.

\section{ANTIRRHINUM}

(Snapdragon)

Snapdragons are especially fine as cut flowers. and also make excellent bedding plants. The wide range of colors and the extra large flowers make then valuable. These seeds are fron choice strains. and strong types of A. Grandiflorum. New and distinct.

Apple Blosson. Clean light pink .... .15.40

Copper Ixing (Indian Summer.) Coppery scarlet, changing to copper color.

Iaralda. Coppery carmine with lemon yellow lip

Snowflake. Pure white

Canary. Pure Canary Yellow

Coral Pink. A delicate shade of pink . .15.40

Fascination. Deep flesh ........15.40

wa 11 f 1 o wer shades. Brown-reds, bronzes, etc.

Defiance. Orange scarlet

Purple King. Deep glowing purple

Old Gold. Bronzy yellow

Oid Golf. Bronzy

Ruby. Ruby red

The Rose. Rosy pink, largest of all.

Mixed. A well balanced mixture of

named varieties. $1 / 8$ oz. $30 \mathrm{c}$

A packet cach of 10 varieties

TALL SNAPDRAGONS

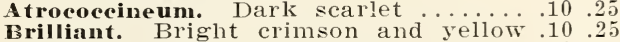

Carmine Kiug. Glowing carmine ..... 10.25

Carmine King. Glowing carmine ....

Coral Pink. Delicate shade of pink ... . .10 .2.

Firefly. Bright red and yeliow.................

Giant Iellow. Large clear yellow ......

Peach Blow. Light pink

othello. Maroon with satiny sheen $\ldots .10 .25$

Queen Victoria. Lalge clear white .... 10.25

Queen ictoria. Lal ge clear white ..... .10 .25

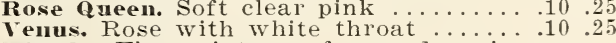

lixed. Fine mixture of named varieties. $1-8$ oz. $25 \mathrm{c}$

A Packet Each of 10 Iarieties $75 \mathrm{c}$

SEVI-DWARF SNAPDRAGONS. Fine varieties for bedding. The colors are fixed and distinct. and the stems are long enough to use as a cut flower.

Atrococcineum. Dark scarlet ......... 10.25

Amber Queen. Chamois sliaded yellow .10

Canary. Bright clear yellow ...........

Cottage Maid. Bright pink white throat .10 .25 
Crimson Queen. Large crimson ......10.25

Fascination. Fine deep pink ..........10 .25

Gloria. Rich rose pink ........................

Velrose. Clear bright rose ..........10.25

Philadelphia Pink. Brilliant pink ... .10 .25

The Bride. Pure pearl white ........10 .25

The Fawn. Terra cotta, overcast yel-

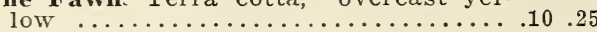

Black Prince. Dark maroon .........10 .25

Mixed. Fine mixture of named varie-

ties. $1-8$ oz. $25 \mathrm{c} \ldots \ldots \ldots \ldots \ldots \ldots$
Packet Each of 10 varieties, $75 \mathrm{c}$

A Packet Each of 10 Varicties, 75 c
RCTOTIS Grandis. A very handsom

ARC'TOTIS Grandis. A very handsome 2 to $3 \mathrm{ft}$. White flowers with center and reverse of petals pale lilac-blue .10 .25

ARGEMONE. Hispida. (Description by Dr. Brand, who coilected this seed) A handsome, white desert poppy with bristly foliage. Grows on the edge the Painted Desert in Arizona. 18 to

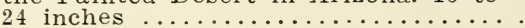

\section{ASTERS}

The following list of Asters presents those varieties which have proven themselves to be the best for their individual purpose. As a cut flower - for bedding purposes - as a bright touch of color in the garden the Aster is unrivaled.

Early Wonder. The earliest of all Asters. Comet type. Branches from the ground with four to six slender stems that are crowned with good sized blossoms. A quick grower, and must not be checked in growth or it will dwarf. White, Rose, Light Blue,

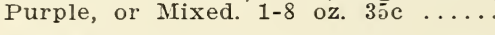

Lavender Gent. A fine upright Aster. Never has a yellow center. Good sized true lavender flower on long stems. $1-8$ oz. $50 \mathrm{c} \ldots \ldots \ldots \ldots \ldots \ldots \ldots$

Queen of the Market. An especially perfect form. ivhite, Rose, Flesh Lavender, Purple, Crimson, Scarlet,

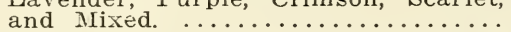

Royal. An early form of the branching Asters. An important variety for the cut flower trade. Clear and distinct colors. White, Shell-Pinl, LavenderPink, Purple, Lavender, Rose, or Mixed. $1-8$ oz. $30 \mathrm{c} \ldots \ldots \ldots \ldots \ldots \ldots$ Sawyer Asterum. A nice variety for
the garden, flowers being well formed and colorful. White, Pink, Lavender, and Mixed.

Sunshine. (Improved Anemone Flowered). A delightful Aster. Petals are twisted and quilled, being covered with tiny quilis resembling miniawith tiny quilis resembling miniaing shades of blue, pink, and deep rose. The long stiff stems makes this Aster a good cut flower variety. ....

Vick's Mikado. The finest of the midseason varieties. Immense feathery sometimes reaching the size of $6 \quad 1-2$ inches in diameter. Extra. White, Pink, Crimson, Purple, and Mixed.

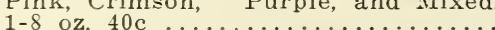

Early Beauty Type. The same habits as the American Beauty Type, being a fine grower, but is earlier. Carmine, Lavender, Purple, Shell-Pink, Rose, White, Crimson, September Beauty, Black Prince, and Mixed. 1-8

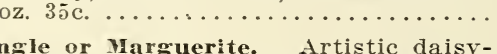

Single or Marguerite. Artistic daisyWhite, Rose, Light Blue, Red, and Mixed.

Ball's White. A new white branching Aster that is easy and free growing. Has attracted a lot of attention.

Pkt Pkt

Ioreton Pink. A fine aster of soft rose pink. No other aster has the shade of this fine novelty. Good sized flowers on long slender stens.

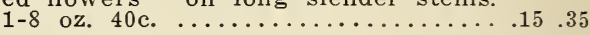

Imperial. An important Aster for making up in floral pieces. Well rounded flowers on stiff stems. Free blooming. Purity, Daybreak, Rose, Indigo on white ground, Rosy-Carmine Yellow overlaid Pink, Lilac, and Mixed. ...........

Giant Branching Comet. A superior upright form. A heavy and fiee grower. For immense size disbud. White, Shell-Pink, Rose, Light Blue, Azure, Dark Blue, Deep Rose, Crimson, and

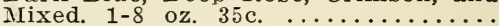

California Giants. One of the most popular in the entire list, and one of the most satisfactory. Very large and strong grower. White, Light Blue, Deep Rose, Purple, Lavender, Peach Blossom and Mixed. 1-8 oz.

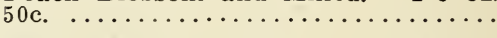

Single California Giants. A delightful addition to the garden Asters. Very showy and dependable. Large single flowers in a fine mixture of soft

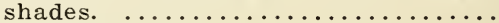

Late American Branching. Probably the best known of all Asters. Splendid either in the garden or as cut flower. Large blooms on stiff stems. Cr.mson, Cardinal, Deep Rose, Lavender, Azure, Peach Blossom, Peerless Pink, Peerless Yellow, LavenderPink, Sensation, Blackish Blue, Purple, White, and Mixed. 1-8 oz. $35 \mathrm{c}$. . Fing Type. Large vigorous grower well covered centers and needle-like petals. Distinct from all others. white, Rose, Crimson, Violet, Shell Pink, Lavender, and Mixed. 1-8 oz.

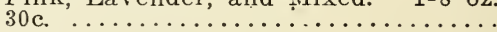

American Beauty Type. Very late and one of the rankest growers. Solid well formed flowers on long stems, White, Shell Pink, Rose, Lavender, Crimson, Furple, September Beauty

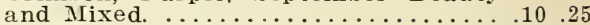

Above Asters Bloom in the order of Their Listing.

\section{NOVELTY ASTERS}

Globe Pyramidal. Closely built and very free flowering type, a beauty for using one plant to a vase or pot. Mixed only. ........................40

Japanese. Artistic flowers, finely cut spiky petals. Comes in bright and odd shades. Useful for cutting or bedding .............................

.20 .50 Peony Perfection. Medium sized flowers. Plant tall and upright. Comes in bright colors and also many bi-

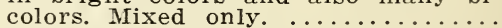

Ball or Jewel. Flowers perfectly round and densely double. Colors show about as Japanese. Fine for cutting. .15 .40

Giant Comet. German upright comet type. Large rather flat flower on upright plants. About 24 in. under upright plants. About 24 in. under maison Pink, Queen of Spain, Ruby. Silver Gray, Sulphur Yellow, White passing to Rose ....................40

Dwarf Chrysanthemum Flowered Taller than Boltze, large flowers. Especially fine for borders and low bedding. Bright colors, and wonderfully free and long standing ........ 
Unicum. Plants about $2 \mathrm{ft}$. tilll, branching habit, flowers of good size with artistic, long tapered florets. Mixed

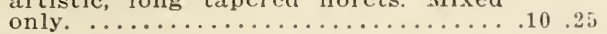

Heart of France. A medium sized branching aster, woll rounded $110 \mathrm{w}-$ ers, very frce, rich dark red. 1-s oz. 45 c. . . . . . . . . . . . . . . .

Crimson Giant. Upright type, about 30 inches tall. Large double flowers of bright crimson, very sliowy border.

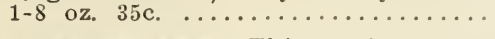

Everlasting Aster. This curious aster was found in the field of the Joln nia, It resembles a huge shell pink Helichrysum, and like it, retains it. color and form when cut and dried. One color only, shell pink .........

Peerless Pink. A Late Branching type with clear bright pink flowers. One of the most useful and attractive of all Asters. 1-8 oz. $20 \mathrm{c} \ldots \ldots \ldots \ldots \ldots$

Peerless Yellow. A fine brilliant color

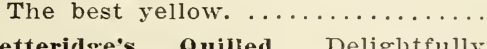

pleasing novelty with rounded cen pleasing novelty with rounded cenWhite, crimson, yellow, light blue,

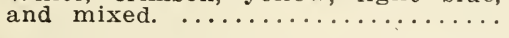

Victoria. An upright type with medium sized compact blooms. A strong and dependable grower. Clear, bright colors. Deep Lilac, Indigo, White Carmine, Salmon Pink (Micaela), and

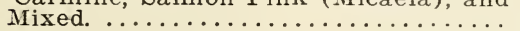

BALLooN TINE (Love in a Puff). A rapid growing annual climber. Succeeds best in light soil and full sun. White flowers with seed pods resembling miniature balloons.

BALSAM (Lady's Slipper.) Old favorite of easy culture, producing gorgeous masses of brilliant colored flowers. New shades and new forms here.

Double Camelia Flowered. Salmon rose, primrose, light pink; scarlet, white,

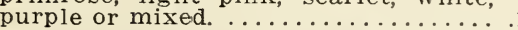

Spotted Mixed, Goliath Mixed, Rose Flowered Mixed, or All Types and

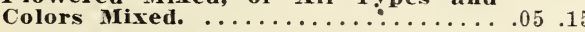

Balsam Apple (Momordica Balsamina). $10 \mathrm{ft}$. A very ornamental and quickgrowing climber. While it has a flower, it is grown mostly for the effect of the fruit which follows. This is yellow, resembling an apple, hence its name. When ripe it opens hence its name. When ripe it opens
and shows the seeds and blood red and shows the seeds and blood red

Balsom Pear. (Momordica Charantia). Like above only the fruit is pear-

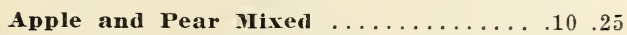

BEAN. Scarlet Runner. Rapid growing

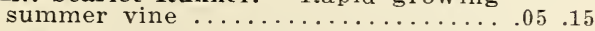

BEGONIA Semperflorens Erfordia. Brilliant rosy carmire.....................50

Luminosa Gracilis. Deep scarlet ..... .20 .50

Fireball. A strinking crimson. ....... .20 .50

BRACHYCRONE Iberidifoiia. (Swan River Daisy). Very pretty in beds. A fine mixture of blue, rose, and

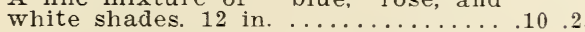

BROWALLA Elata. Fine for bedding or potting. A dainty nodding flower.
Blue, white, or mixed $\ldots \ldots \ldots \ldots \ldots \ldots .10$

CALCEOLARIA Hybrida Tigrinia. A bright orange, tiger spotted. .........35

Mixed. Spotted and self colors. Striking pot plants for greenhouse or

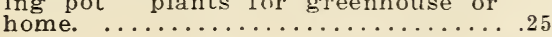

CAII:NI)IA (Pot Marigold). One of the best easicst, and showiest of all ill nuals. Fine for cutting.

landio. A new brilliant globular orange with quilled petals. Finc.

campfire. A beatiful orange flame color. New. Rieconmmended. $1 / 60 \%$ $\$ 1.25$

(10)

Orange ling. Fine decp orange. $1 / 4$ oz. 40

Favorite. Cream striped yellow. 1/4 oz. 35c. ... . . . . . . . . . . . . . . . . .

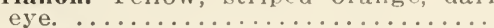

Lel'roust. Nankeßn yellow with dark center. $1 / 4$ oz. $35 \mathrm{c}$

Ball's Florists' Struin of Orange liing. An extra select type of Orange King larger in every $w$ ay and more double

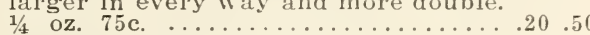

Sulphur Crown. Lemon ............10.25

CALLIOPSIS. Showy free annuals of easy culture. Must have full sun; in bloom all summer. Fine for cutting. and the dwarfs are extra good for edging.

Tinctoria. (bicolor), Yellow and brown .05.15

Coronata Iaxima. Tall orange spotted brownish purple.

Nana Compacta Bicslor. Dwarf yellow and brown

Crinsol King. Splendid bedder ......05.15

Golden Wave

Radiata Mixed

$.05 \quad .15$

Finest Tall Varicties Mixed. A splendid new mixture.

Tall Double Mixed. A choice mixture of doubles.

CANN 1. Taken from the largest collection in this nursery district

.10 .25

CARDINAL CLIMBER. A splendid new climber with dark green, finely cut foliage, bright red flowers

*CANDY TLET. A most useful hardy annual.

Dwarf Hybrids. A beautiful border, free blooming dwarf, colors range mostly in pale pink, lilac, mauves, to

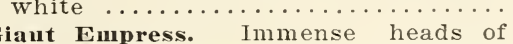

Giant Empress. Immense heads of

Giant Hyacinth-flowered. Pure white, reselected

Umbellata. Finest mixed

Queen of Italy. Free flowering, dwarf, compact. with almost evergreen foli age. May be grown as annual or bi ennial.

CELOSIA Childsii (Chinese Wool Flower). The most curious and showy of all Celosias. A gorgeous effect for tall massing, and unusually fine for cutting, especially the yellows and cutting, especially the yellows and pinks. This is reordered more than any other annual in our list. We of-
fer this season, White, Yellow, Crimson, Light Pink, or Mixed

Chrysantheflora. Immense flat heads of brightly colored flowers. Fine for cutting. One of the best introducMixed only

Pride of Castle Gould. Wonderful feathery heads of rich shades. Much

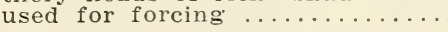

Plumosa (The Plumed Cockscomb.)

Aurantiaca. Orange yellow ......... 05.15

Kermesina. Crimson ............... 05.15

Thompsonii. A magnificent giant strain of mixed colors, yellow, scarlet cream etc.

Cristata (True Cockscomb) 
Glasgow Prize. Immense showy, dark

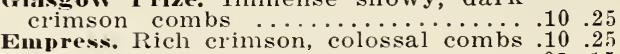
Dwarf lixed

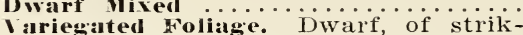
ing effect, bronzy red leaves, beautiing effect, bronzy red leaves, beauti-
fully spotted and shaded yellow and crimson. Combs of velvety black

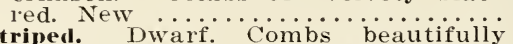
stliped in various colors, as yellow, rose, red, violet, etc. Very effective. rose, red, violet, etc. Very effective.

I'all Iixed. A mixture of bright colors $\ldots \ldots \ldots \ldots \ldots \ldots \ldots \ldots \ldots$

COSMIDIUI Hurridgeianum. Orange Crown. Beautiful hardy annual sim1/4 oz. Golden Iellow. Bright yellow form of

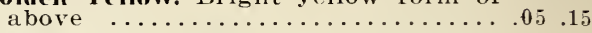

cosMos. Strong growing plants witl handsome foliage. Old favorites for cutting. Large flowering in follow ing colors:

Lady Lenox, White, Crimson, Pink or

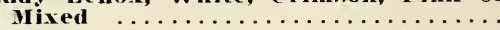

Early Flowering Giants, White, Crimsoll, Pink or Mixed ............

Early Double Crested. Anemone flowered form of early giant cosmos. Extra for cutting. White, Piuk Benuty, Crimson or Mixed. 1/t oz. $75 \mathrm{c}$. .....

Double White, Rose, Blue, Maroon or Mixed $\ldots \ldots \ldots \ldots \ldots \ldots \ldots \ldots \ldots \ldots \ldots \ldots \ldots$

Gymnocarpa. Much used "Dusty Mil-

Americana (Basket Flower).. Very

Cate Double Crested. This new forn of Cosmos is not strictly double but much resembles the double form of Pyrethrum Roseum. A grand addition to the list of late flowers for cutting. Four colors separate: Pink, Red, White, Malmaison Pink or Mixed. $1 / 4$ or white. Extra for cutting or for making up

Imperialis (Sweet suitain) Finest strain for forcing, best Italian. Naple grown stock

White, White and Rose, Delicate Lilac, Purple, Yellow or Mixed sia
Iphigenia. The finest Sweet sultan for cutting or for florists design work. Pink and white

Amaramthus. Red. Neiv $\ldots \ldots \ldots \ldots \ldots \ldots .15 .35$

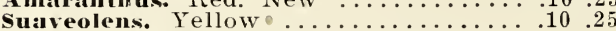

('HRYSANTHEMUM. Showy and effective summer flowering annuals, much used for summer cutting. Not grown as extensively as they deserve. Easy and free.

Burridgeanum. Pure white petals with zone of brownish red and inner zone

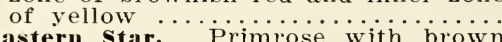

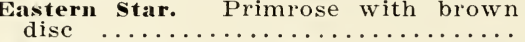

Evening Star. Rich deep yellow ..........

Iorning Star. Primrose yellow. Single

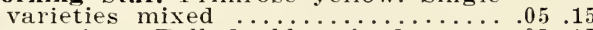

Coronarium. Tall double mixed ...... .05

Radiatum Hybridum. Quilled and whee shaped flowers in shades of white to orange. Artistic and fine for cutting.

CINERARIA. Fine pot plants for greenhouse or home

Hybrida Grandiflora. A choice mixture.

\section{Deep Bright Bive}

Old Rose

Sharp Crimison

plant. Tybids. Enormous flower and finest shades and colors

NogLossum Amabile. Chinese Forget-me-not. Fine blue color. 18 in.

Amabile Pink. This delightful novelty first introduced by the Royal Botanical Gardens at Kew, England. Rich, ical Galdens at Kew, England. Rich,
deep pink flowers. Same habit as the

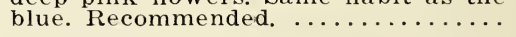
$05 \quad .15$

COIX Lachrimae (Job's 'Tears). Orna-

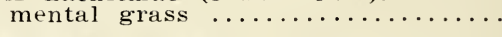

DRACENA Indivisa. The slender dracena much used in bedding ........

DATURA (Angel's 'Trumpet.) Three to five ft. plants bearing immense trumpet shaped flowers ................

DAHLIA. Very easy from seed. Produces splendid bloom first season. Sow early inside; transplant after frost.

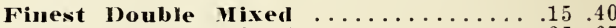

Double Cactus nixed $\ldots \ldots \ldots \ldots \ldots \ldots \ldots . .25 .65$

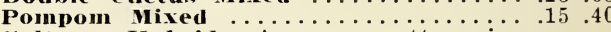

Coltuess Hybrids. A very pretty mixture of choice flowers in dazzling shades. Beautioul dwarf singles .... .25 .65

DELPHINIUM AN NAL (Larkspur) Tall double stock flowered; the finest of this class. Tery useful for backgrounds in the annual bed, and for
cutting. The soft pastel colors and cutting. The soft pastel color's and led in any other plant. Seeds are best sown in fall, but will come nicely if sown in very early spring, even broadcasted on top of the Marcl snows.

tems. Easily grown annuals. Long stock flowered delphiniums. Easy and free. Fine for vases or border

Double White, Apple Blossom, Salmon Queen, Scarlet Queen, Purple Prince Orange Queen, Chamois Queen, Ruby King, or Mixed. $1 / 4$ oz. $25 \mathrm{c} \ldots \ldots \ldots \ldots$

CLEOME (Spider Plant). Very useful in heavy borders, or in tall perennial which have bloomed early. Makes height of $31-2 \mathrm{ft}$. Sow outside early and give plenty of room.

Gigantea. Bright rosy crimson. $1 / 4 \mathrm{oz}$. $20 \mathrm{c}$

Gigantea Hybida. Fine new hybrids varying from white to lilac, rose

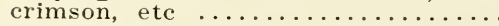

COBEA Scandens (Cup and saucer time or Catledral Bells). Climbers of very rapid growth, valuable for covering trellises, etc. In sowing, place seeds edgewise and cover lightly. Blue, White, or mixed. $1 / 4$ oz. $25 \mathrm{c}$.......

COLEUS Rewalis. King's Coleus rainbow

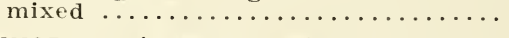

CONVOLULE's, Major. (Morning Glory) This fine climber is one of the most popular. A fine mixture of clear

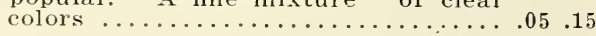

Ageratum Blue
Bright Rose
Dark Blue
Flesh
Light Blue
Lilac

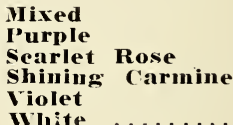

1) a

Exquisite Rose. A fine new novelty. Very graceful and compact. The flow ers are a delicate rose. Highly re-

commended .......................... neater and more compact. A beauti-
ful shade of coral pink. A very fine

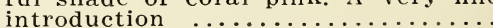

La France. A lovely salmon pink shade of the Exquisite type. Of remarkable form and texture. Very satisfactory

Miss Califormia. Considered on the Pacific Coast as the acme of perfection. ific Coast as the acme of perfection. double. Distinctive and recommended. Anse.............. of the best of re-

cent introductions from the Pacific Coast. A distinctive shade of rose overlaid with salmon. A free

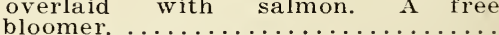

ball Hyacinth Flowered. White, Violet, Rose, Reddish Gray or Mixed ......10 .25 
Dwarf lloeket. Mixed

I'all lboeket. Mixed

$.05 \cdot 15$

canclelabra leormed laterkur. Pretty

pyramidal sort about 14 inclies tall.

linitio e(olol.

$.10 \quad .25$

* DIAN'Jils (ciarden Pink)

lisatern Queen. lisatifully marked rose ...............................

Mueen of Hollmul. The finest white .. .10 .25

Marvelous Mixel. This remarkable strain produces large flowers, double witl tine tluread-like fringes. All shades from white to deep purple-red

Iacinatus striata. Striped and blotehed items in the fringed pinks. Special

Nobilix. (lioyal Pink). "Large flowers ill bright sliades. Plant very robust. foliage dark green tinted brown.

Nireball a brilliant double. Flame scar-

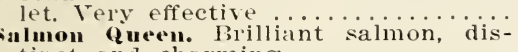
tinct and charming

IIISCIS Corrulea. (Lace Plant) Fine for cutting. Large flat lace-like flowel's of light blue, on long stems. This has been offered for some years as Queen Anne's Blue Lace Plant ......

DIMORPHO'THECA. Extra for low dwarf border. Persistent and free blooming border. Persistent and free blooming
Upright flowers of bright orange, Upright flower's of brig

urantiaca. Golden West

Aurantiaca Hybrids. Mixed

IOLICHOS (Hyacinth Bean). Rapid an nual climbers, with large heart shaped leaves. Tery useful for quick shade, and very ornamental. Easily grown.

Soudanensis. A Japanese sort with rosy

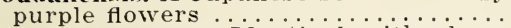

rintzess Helene. Identical with above except that flowers are pure white and foliage lighter in color

Iixed

ESCHSCHOL'TZIA

(California Poppy) ittractive annuals for beds, massing or edging, free flowering, with very or edging, free flowering, with very from June till frost. The yellow sorts and the blue Centaurea make a beautiful combination. (Do not try to transplant these.)

Alba FI. PI. Double white $1 / 4$ oz. $25 \mathrm{c}$

Ballet Girl. Cochineal Carmine, reverse side creamy white $1 / 4$ oz. $25 \mathrm{c}$

Chrome queen. Anber yellow. $1 / 4$ oz $25 \mathrm{c}$

Carmine King. Carmine rose on both

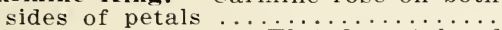

Caniculata Crocea. Fiuted petals of

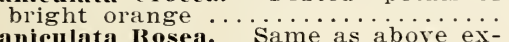
Caniculata Rosea. Same as above except rose color $\because \ldots \ldots \ldots \ldots \ldots$. $\ldots$ ground.

Dainty Queen. Coral on cream ground. Golden West. ' The largest flowering of this poppy. Butterfly yellow with

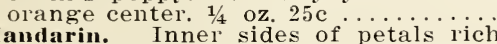
Iandarin. Inner sides of petals ric
orange, outer side brilliant scarlet

orange Flame. Tivid orange scarlet.

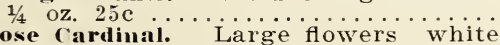
Rose Cardinal. Large flowers white inside, rose outside The Geisha. Inside brilliant gold, outside orange crimson. Fluted petals.

Tango. Bronze red, overlaid teria cot-

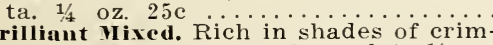
son, pink, orange and scarlet. $1 / 4 \mathrm{oz}$. son, pink, orange and scarlet. 1/4 oz.

A packet each of 10 varieties 75 c.

EUPHORBIA Variegata. (Snow on the Mountain). Belongs to the Poinsettias and like them, blooms in bracts. Teined and margined white Heterophylla. Tery ornamental foliage plant, much similar $t o$ the well

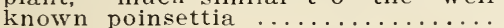

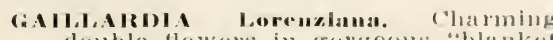
double flowers in gorgeous "blanket flower" sliades. basy and free blooming. Mixiel.

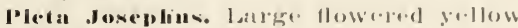
(.) lige.

II color:

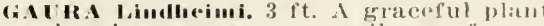
bearing numerous spikes of rosy white flowers from July until fo:t Fine for cutting

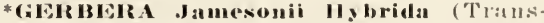
vaal Daisy') clioice mixture, 30 steds .2.

GILIA. (apitata Blue. (IBlue 'Thimble Flower.) A bushy two foot plant covered with bright blue scabiosilike flowers. Fine as a cut flowel and dries to color beautifully

$.10 \quad .25$

GODISII. V'ery attractive hardy an nuals, doing best in poor soil. Sllow er's of showy, satiny flowers in rich color's. Superb for bedding.

Cherry Red. Tall double. A striking fiery cerise. Excellent for bedding or cutting.

Azalea Flowered 'Sall. Double flowers of vivid colors. Fine as cut flowers. Brilliant mixture

Azalea Flowered Dwarf. For growing in pots or beds this variety is especially fine. Delicate colors in a

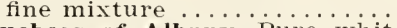

Duchess of Albany. Pure white $\ldots$.
Duke of York. Laige flowers of a rich glittering crimson with white center, A showy variety which should be used freely in beds and borders

Gloriosa. Blood red

Lady Satin Rose. Bright rose

Briliant Mixed

.10 .25

GYPSOPHILA (Baby Breath). Free flowering panicles of bloom much used for mixing with other cut flowers.

Elegans Ilba. Annual White. Oz. 25c .05 .15

Elegans Rosea. Annual Rose. Oz. 25c. 05.15

Elegans Carminea. Carmine form of

GOMPHRENA. Probably the easiest and surest grower among the everlastings. Stiff, clover-like flowers on strong stems. Purple or mixed HELIOTROPE-Lemoine's Giant. Mixed
color's in the finest possible strain

HELICHRYSUM MONSTROSUM (Straw Flower.) Canary yellow, crimson Fireball, Silver Ball, Rose Carmine, Scarlet, Tiolet Queen and Mixed

HOLLYHOCT Hybrida Semperflorens. (Ever Blooming Annual Hollyhock) A brilliant mixture of free flowering A brilliant mixture of free flowering background. 6 feet. Single mixed

Double Mixed

HUNNEMANNA Fumariaefolia. (Bush Eschscholtzia.) Bushy plants quite similar to California Poppies. Flowers keep well when cut. Bright yellow.

*IONOPSIDICM Acaule. (Tiolet Cress) Flowers white tinged with cleal violet. A beautiful miniature. Especially fine for the rockery. Sows it self freely when established. Recommended. 3 inches

IPOMOEA. Climbers of rapid growth, beautiful and varied flowers. Fo trellises walls.

Coccinea (Star Ipomoea.) Small scarlet flowers. Oz. $25 \mathrm{c} . \ldots \ldots \ldots \ldots \ldots \ldots \ldots$

Grandiflora Mexicana. (Moonflower)

Black seed or White seed. Black is
best for outside planting. . . . . . .
Iorning Glory, Rochester Pink. extra fine giant pink 
Imperialis (Japanese Morning Glory). Pkt Pkt

Ipomoea Quamoelit. (Cypress Vine). One of the most popular vines, very delicate fern-like foliage and masses of small star-shaped flowers. White,

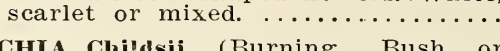

ÍOCHIA Childsii (Burning Bush or Summer Cypress). A very easily grown annual attaining a height of about three feet. The plants which
resemble Cypress in summer, change to carmine and blood red in autumn. Flowers small scarlet. A splendid or-

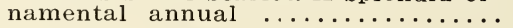

LANTANA Iybrida Mixed. Desirable greenhouse or bedding plant. In like flowers in nasturtium shades. .

LAVATERA (Annual Mallow) A beautiful and showy annual. Persistent bloomer. $2 \mathrm{ft}$. Fine for bedding. Rose, white or mixed ...............

LEPTOSIPHON. New French Hybrids. An elegant dwarf in varying shades golden yellow and bright orange,

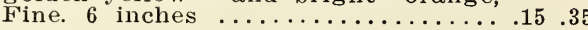

LINARIA. Maroceana Hybrids. Rich colors of red, purple, and white in a fine mixture. Grows about 12 in. ...10 .25

LINUM Grandiflorum Rubrum. Red annual flax. Easy and free ............. .05 .15

*LOBELIA. Compaeta. A very desirable low border plant which gives a brilliant touch to the border or to the rockery. This fine annual is also extensively used in porch boxes and pots.

Sky Blue. Beautiful shade of blue. 4 in. .10 .25

Crystal Palace. Brilliant blue .........10.25

Dwarf Sorts Mixed. A fine mixture ... .10 .25

Hybrida-Sapphire. A lovely novelty. Intense sapphire blue with white eye.

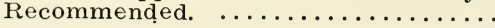

LUPIN. (Annual). Free flowering, easily grown annuals, with long gracefu spikes of rich and various colored pea-shaped flowers. Valuable for border or cutting.

Hybridus. Deep scarlet and white, Rosy purple, Rose, Crimson, or mixed. ....... White. Dark Biue, Rose Sky Blue and finest mixed .........

LOPE. Showy plants for the border. Flowers large and handsome. $2 \mathrm{ft}$ White, crimson, purple or mixed

\section{MARIGOID}

Old favorite free flowering annuals. We offer two types below, the African and French. The first named are the large flowering and run to yellow and orange shades and are well adapted for large beds and mixed borders. The French are more dwarf and flowers are generally striped in yellows and mahogany browns. Both are very easily grown.

\section{AFRICAN MARIGOID}

Eldorado. Large imbricated and extremely double. All shades of yellow $.10 \quad 20$ Lemon Queen. Soft lemon yellow flowers o....................... Intensely doube flowers of a rich, deep golden orange. A fine contrast to Lemon Queen

Pride of the Garden. Immense flowers densely double, dwarf, compact growth, forming dense bushes 15 to

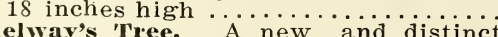

\subsection{0}

10.20

Kelway's 'Tree. A new and distinct type. Often reaching $4 \mathrm{ft}$. Various
colors. Mostly single. A great addition to the tall Marigolds $\ldots \ldots \ldots \ldots \ldots .20 .50$ Tall Double Mixed ................... Dwarf double mixed. A good mixture .05 .15

FRENCH MARIGOLD

Tall Double Striped Mixed. Fine for

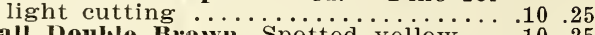
Tall Double Brown. Spotted yellow ... 10.25 Silver King. A.very effective lemon and chocolate single

Dwarf Double Dark Brown ................. Dwarf Double Golden Yellow. Brown
margin $\ldots \ldots \ldots \ldots \ldots \ldots \ldots \ldots \ldots \ldots .10$ Dwarf "Piginy" Golden Baii. Double .10 .25

Dwarf Single Diadem. Yellow with mahogany eye ................. 10.25

Dwarf Single, Gold star. Yellow strip-

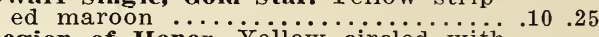
Legion of Honor. Yellow circled with

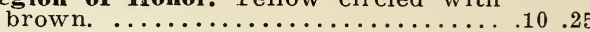

Dwarf double mixed $\ldots \ldots \ldots \ldots \ldots \ldots .05 .15$

A11 Types and colors mixed $\ldots \ldots \ldots \ldots .10 .25$

MESEMBRYANTHEMUM Crystallinum. (Ice Plant). Well known plant for boxes, vases, or edging ............

MARVEL OF PERU (Four O'clock) A well known garden favorite. It is gaining in popularity as a border for walks and drives.

Tall. Mixed $\ldots \ldots \ldots \ldots \ldots \ldots \ldots \ldots \ldots .05 .10$

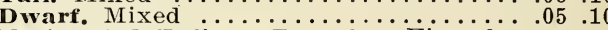

Variegated Foliage Dwarf. Fine for borders, mixed ..................... 05

Tall. Variegated foliage, mixed ....... .10 .25

MIGNONETWE. Very rapid growth, rather dwarf delicately scented. Does best during the cool months. Plant either very early or very late or both for succession.

Allen's Defiance. Largely used for forcing. A splendid sort and of good keeping qualities, when cut. $1 / 4 \mathrm{oz}$.

olden Queen. Light golden yellow. $1 / 4$

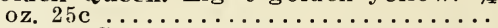
oz. 25 c stro............................ ses of bright red flowers on strong. stiff stalks. Surpassing all others in brilliancy of color. Especially adapted for florists use. $1 / 4$ oz. $50 \mathrm{c}$..................

Goliath Golden Yeliow. New, extra fine ................................. Pyramial growth. 2 ft. Immense red flowers. New spirai. Spikes 8 to 10 inches long, very fragrant. $1 / 4$ oz. $25 \mathrm{c}$ arge Flowering Gabrielle (Imperialis)

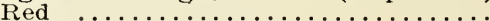

True Maehet. Thick, dark green leaves Gray flowers. $1 / 4$ oz. $25 \mathrm{c} \ldots \ldots \ldots \ldots$ White Pearl. Enormous spikes of pure white flowers, very fragrant, new

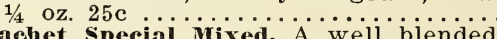

\section{NASTURTIUM}

Probably the best known and most used of any annual.

Dwarf Finest Mixed 1 oz. 20c $\ldots \ldots \ldots .05 .10$ Dwarf Dark Leaved Varieties. 1 oz. $20 \mathrm{c} .05 .10$ Tall Varietgated Leaved Mixed …....10.25

Tall. Finest. 1 oz. $20 \mathrm{c} \ldots \ldots \ldots \ldots \ldots \ldots . .05 .10$

Tall Dark Varieties Mixed. 1 oz. 20c .. .05 .10

PEREGRINUM (Canary Creeper or Canary Bird Flower.) Flowers yellow, fringed, most popular creeper .......

NEMESIA Compaeta, Triumph Mixed Extra fine strain of this favorite annual. All colors $\ldots \ldots \ldots \ldots \ldots \ldots \ldots$. crimson, orange and scarlet or mixed

NEMOPHILA Insignis. Blue. Clusters of

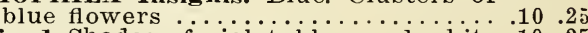

Mixed. Shades of violet, blue, and white .10 .25

NIGELLA (Love in a Mist)

Miss Jekyll. Beautiful new variety with cornflower blue blossom, fine for

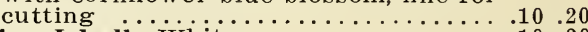

Miss Jekyli. White ................

NICOTIANA (Flowering Tobaeeo.)

Sanderae Hybrids. Delightfully sweetscented tubular flowers of various scented tubular flowers of various

colors
Affinis. Pure white, sweet scented $\ldots . .10$ wew Hybrids, Flesh, Crimson, violet, or

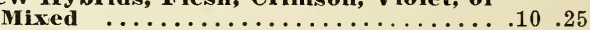

ORNAMENTAL GOURDS. Small sorts, round, pear shaped etc. in various shades of green, yellow, and white, climbing vines giving good shade. Oz.

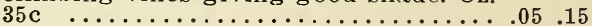


PETUNIA

\section{(GIAN'T' 'TY'P's)}

Finest Luropean strains of this valuable item.

Giant yixed 1 Pkt Pkt of our test sorts, plain and fringed. Colors of finest shides only. Self colors, pinks, wlites, deepest velvety redish purples, mottled, etc. 1000

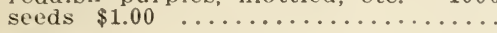

Almiration. (Balcony Qucen.) Decp violet blotelied white .......................

Elegans. Deep blood red, white throat. .10 .25 Julius Woln. Light blue, giant flowers

linew Edward vir. White with crimson

Lutea. Fringed. Giant light yellow . . .10 .25

Titauia. Royal purple, white margin, fringed $\ldots \ldots \ldots \ldots \ldots \ldots \ldots \ldots \ldots \ldots \ldots \ldots \ldots$.

Giauts of Califoruia. Finest giants in

Flufy Rufrles. A beautiful introduction. Single flowers in mixed colors so finely fringed that they resemble doubles. 1000 seeds, $\$ 1.00 \ldots \ldots \ldots \ldots \ldots$

Giant Double Mixed. Double petunias are notoriously fickle as to coming double. This is the best strain we have been able to find after many seasons of trials. Save the weaker seedlings. They produce the finest flowers of best colorings. 500 seeds $\$ 1.50 \ldots \ldots \ldots \ldots \ldots \ldots \ldots \ldots \ldots \ldots \ldots \ldots$

Triumph. Medium sized, densely double flower of deep violet blue. A fine

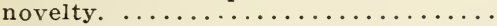

Pepita. Dark carmine, changing to scarlet, with white border. New ....

Rosalind. Large flowèrs of delicate

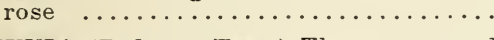

PETUNIA (Ralcony Type) These are good bedding sorts, but are extra fine for boxes or vases, in that they are natural "trailers." Flowers are large and colors extra good. Pink, red,

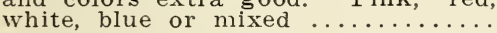

Pride of Portland. Deep pure rose, nicely fringed. Very fine for basket,

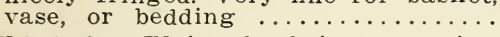

Elk's Pride. Plain edged, immense size, The darkest purple petunia. ........

Fringed Single Scarlet Beatuy. Portland type, extra large, fine scarlet .

Pink Triumph. Clear bright pink, delicately fringed. The best fringed pink.

\section{BEDDING PETUNIAS}

Rosy Morn. A beautiful variety for edging. Rather dwarf, of compact growth. White throat, edge flushed soft rose. $1 / 4$ oz. $75 \mathrm{c} \ldots \ldots \ldots \ldots \ldots \ldots$

Bedding White. Purest white for use with Rosy Morn. 1/4 oz. $40 \mathrm{c}$.......

The Queen. Brilliant rose and white,
fringed. Beautiful.

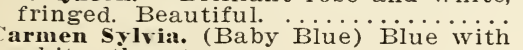
white throat (Baby Blue) Blue with

Norma. Pale blue witli white star, fine

Rose of Heaven. Fiery bright rose. Fine for bedding . . ............ shade in beding

Silvery Lilac. A new shade in bedding petunias. Distinct and pretty $\begin{gathered}\text { I } \\ \text { Compacta }\end{gathered}$ mixture with the widest color range to date. Contains lilac, rose, carmine crimson, with varying throats, starred and marbled.

compacta Violacea. $\quad$ v very fine bed

ding type of a distinct violet shade. Howard's Star. A magnificent variety
free blooming, crimson maroon with a well defined pointed star of blush white. An early bloomer and con-

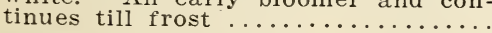

* PIIACELIA Campanularia. A beautiful large brilliant blue flower on nine inch stems. Charming for the rockampanuiaria aiba. Tery pietty white

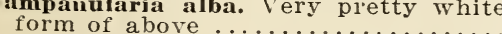

PHLOX Drumenoneli. lime for bedding or eutting. A mixed bed of this is most gorgeous sight. White hose, Siesh, Lilac, Primrose, e, or Mixed.

star of quedlinburs (Star Plilox) Smaller than tlie type. Long strimmr. good colors. Fine. Mixed only

Fimbriata (Fringred Plulox I)rummond) New lacinated and fringed in protty sliades

Semiplen: (Semi-double Phlox Drummond) Half double flowers in fine colors. New .....................

Nama Compacta. A brilliant and showy dwalf Phlox. Ideal for bedding, and can be used to give color to a rock garden

\section{POPPY}

Sow in fall or as early as possible and where they are to remain. 'They will not stand transplanting. To get best results thin to $3 \mathrm{or}^{4}$

\section{SINGLE ANNUAL POPIIES}

Mephisto. A splendid fringed scarlet single, spotted black

Danebrog. Brilliant scarlet with silvery white spot on each petal, forming a white

Tulip (Glaucum.) One of the most brilliant. Flowers resemble the brilliant Gesneriana tulip

The Bride. Beautiful, large, pure white $\begin{array}{lll}.10 & .20\end{array}$

Flanders ( True). Brilliant crimson .. .05 .15

Shirley. Fxtra Dwarf, blue shades ... . .10 .25

Shirley. A mixture of wonderful brilliant colors

\section{DOUBLE ANNUAL POPPIES}

Imerican Flag. Flowers very large, snow white, bordered scarlet. Oz. $20 \mathrm{c}$ liant colors, fine for cutting if cut in bud. Cherry Red, Heliotrope, in bud. Cherry Red, Heliotrope, Pink, Vermillion, Ped, White and

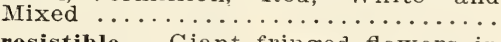

Irresistible. Giant fringed flowers in Rose Shades, often reaching five eony Flowered. Giant balls of brilliant colors, easy and free. Cardinal, Black, Rose, Lilac, Violet, SalmonPink, White, and Mixed ...........

The Queen. New; a double Shirley mixture. This contains all the gorgeous combinations of the Shirley type; lasts well when cut. A fine addition to decorative poppies. ....... Double shirley, Eldorado. Salmon
shades $\ldots \ldots \ldots \ldots \ldots \ldots \ldots \ldots \ldots \ldots \ldots \ldots$

Double Shirley, Eldorado. Pink shades

Shirley. Ryburgh Hybrids. Extra fine strain of Shirley

Tall Double White Colossal. A handsome double variety .........................

Tall Double 'Taplow Pink. An unusual shade of pink. Tery pretty. ........

*PORTULACA Grandiflora. (Moss Rose) An excellent subject for the rock garden. A brilliant mixture of delightful colors. Low growing annual which can be sown in any sunny location and it will do well. 1/4 oz. $25 \mathrm{c}$

Grandiflora fi. pl. The double variety. A splendid mixture of exquisite colors Recommended

05.10

RHODANTHE. Manglesi. An Australian Everlasting of unusual beauty. Bi color flowers of rose and yellow. 12

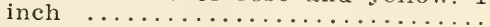

Ianglesi Double. The double form of the above. A most attractive flower. .15 .35

RICINUS Zanzibariensis. (Castor Oil Plant). Has luxuriant and rapid growth. Foliage plant. 10 to $12 \mathrm{ft}$. 


\section{SALPIGLOSSIS (Painted Tongue)}

One of the greatest favorites among annuals.

Emperor. Forming one leading stem bering on the summit a bouquet, about i 2 to 20 inches tall.

Brown Veined Gold

Crimson Veined Gold ............. 10.25

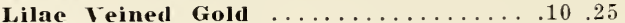

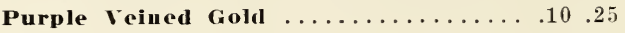

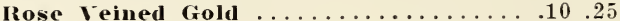

Scarlet Veined Gold ............. 10.25

Violet Veined Gold ................ $10 \quad .25$

Velvety Red ................. 10.25

Improved Tall. Large Flowering .... .10 .25

Finest nixed ......................

SAIVIA. (Scarlet Sage). Sow early in doors, give it plenty of time. Too dools, give it plenty of

Harbinger. Scarlet Bedder. A new Salvia which is extra early and dwarf. Very uniform in growth, the brilliant scarlet flowers are ideal in a bed. One of the finest bedding annuals. An introduction of high merit. splendens. The well known tall vari-

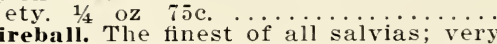
ireball. The finest of all salvias; very
erect and wonderfully free flowering Flowers which appear very early, are a brilliant deep scarlet. A splendid bedding variety. $1-8$ oz. $60 \mathrm{c}$...

Farinacea. Violet blue. $1-8$ oz. $60 \mathrm{c}$.

Zurich. A splendid dwarf sort. $2 \mathrm{ft}$. Earliest salvia to bloom. 1-8 oz. $60 \mathrm{c}$.

15.40

*SANVITALIA Proeumbens. This is a low border plant sometimes called creeping miniature Zinnia. Dark purple disk with yellow rays, resembling small Rudbeckias. Blooms late into the autumn. 6 inches. ....

SCABIOSA (Mourning Bride). Beautiful on long stems, splendid for cutting, bed or border.

Ageratum Blue
Black Prince
Flesh Pink
Yellow
White

Lilac
Azure Fairy
Cherry Red
Fire Iing
Rose
Iixed

Any of the above colors Mixed

Packet of Each of above io colors 60 c Peach Blossom. The Royal Horticultural Society of Great Britain cited this Scabiosa for its beautiful hues of Peach Pink. Serves excellently as a cut flower

Shasta. A new white of excellent merit. Large flowers of pure pearl white. Recommended.

SCHIZANTHUS. Largely used as a stove or house plant.

Wistonensis Excelsior. The finest of

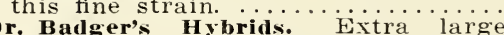
Dr. Badger's Hybrids. Extra large flowers in exquisite shades, new .. .15.40 Rose and Amber Shades. New. . . . . . . . 40

*SEDUM. Coeruleum. (Blue Stonecrop.) This delightful annual sedum is being widely used in the alpine gardens. It gives a bright touch to the rockery all summer. Recommended.

STATICE Sinuata. Splendid for dried bouquets. One of the best everlastings. White, Blue, Rose, Lavender, or Mixed.

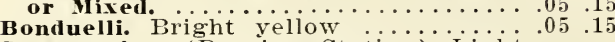

Suworowi. (Russian Statice.) Light rose, shaded crimson. Good stem. Finest for drying.

hardy annuals; sown in iarch and April they commence flowering in April they commence flowering
July. Large Flowered Dwarf Tell-Week Blood Red.

Canary Yellow.

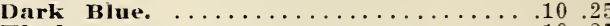

Pkt Pkt

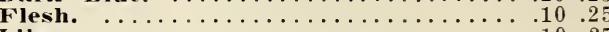

Lilac. $\ldots \ldots \ldots \ldots \ldots \ldots \ldots \ldots \ldots \ldots \ldots \ldots .10 .25$

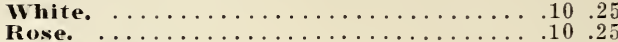

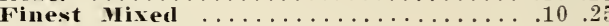

One Each, Seven varieties, 50c.

STOCIIS Early Giant Imperial. (Improved Bismark) Growing from 24 to 30 inches tall; of branching habit. Tery eally blooming and producing a higl percentage of doubles.

\begin{tabular}{|c|c|}
\hline $\begin{array}{l}\text { Appleblossom } \\
\text { Blood Red. } \\
\text { Dark Blue. } \\
\text { Canary Yellow. }\end{array}$ & $\begin{array}{r}\text { Purest Rose. } \\
\text { Lavender. } \\
\text { White. } \\
\text { Vixed. }\end{array}$ \\
\hline
\end{tabular}

Early Giant Imperial, Golden Rose. A large, rose shaded stock, having each floret tinted with a golden

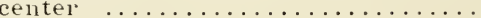

Early Giant Imperial, Antique Copper. The individual florets are extremely large, and are delicately coloured with a rich crimson, overcast with a copper giving a shaded effect ....

Early Giant Inperial Elk's Pride. One of the most recent and finest introductions. Rich Royal Purple. The flowers are of excellent texture. Pecommended. $\ldots \ldots \ldots \ldots \ldots \ldots \ldots \ldots$

SCNFLOWR (Helianthus). Few people realize the effect that may be atccomplished by the use of the sun-
flower. The Chrysanthemum and cut and Come Again types are remarkable for the stately growth, size and brilliancy of their flowers, making a very good effect among shrubbery and for screens. Hardy annuals.

Iaroon Prince. A splendid dwarf for the border for beds. A free bloomer with clear maroon flowers. .10.25

cueumerifolius Purpurea. (Red Annual Sunflower) A beautiful and easily grown novelty, $3 \mathrm{ft}$. All shades from yellow through different shades of red, down to chocolate. A distinct break in color of this popular annual. Very artistic and well worth growing. 1 oz. $25 \mathrm{c} \ldots \ldots \ldots \ldots \ldots \ldots$

cut and Come Again Sumflower. (The Everblooming Type). The single flowers, three to four inches across, are borne on long stems admirably adapted for vases. Choice colors in

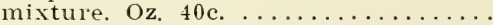

Do u l l Chryanthemun Flowered. Grows about six feet high and bears profusely. The perfect double flowers are bright yellow of different sizes; from three to six inches in

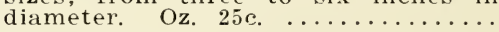

Large Russian. A very tall growing single variety, 10 to 15 feet. The seed used for poultry. 1 oz. $10 \mathrm{c}$.

\section{SWEET PEAS}

\section{EARLY FLOWERING SPENCERS}

Iuch earlier than the standard Spencel type which makes them especially valuable for forcing, or for outside culture, where summer heat is hard on the main crop. Size and type identical with the late Spencers.

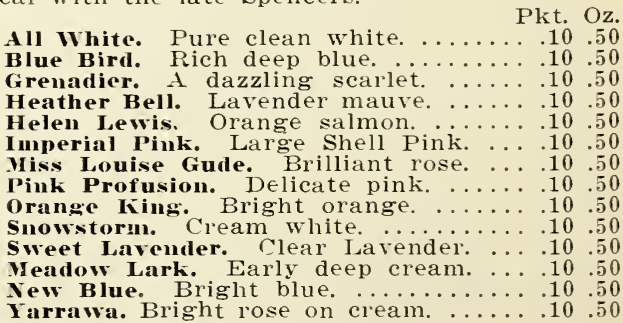


Extra Garly Mixel. Jinem named

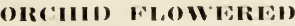

Splendid collection of tricel sorts. Gach one is really rince.

Austin Irederiek. Improvel griant lavender .............................

Iarbara. Orange salmon.

Clurity. Bright crimsoll

constunce Hintom. Giant white..........

countess snencer. bright rose. Fine. 10.25

Defiance. Orange scarlet. . . . . . . 10.25

Dobbie's Cream. Deep primrose. .... . 10.25

Elfricala Pearson. Giant light pink. . .10 .25

Goldel Glory. Deep gold. .......... 10.25

Hawluna link. Pinkish rose. . . . . . 10.25

Heavenly bluc. Delphinium blue. Fine. .10.25

Helen Lewis. Orange tango............ 10.25

I ary Piekford. Cream and pink........ 10.25

pink Perfection. A fine deep pink. . . .10 .2

Royal Purple. Rich purple. ...........

Royal Seot. Brilliant sarlet ……

Tangerine Improved.

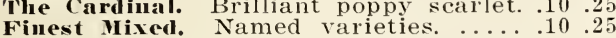

Your Choice of 'Ten Packets äe

*'IAGETES. Simuta Pumila. Dwarf compact miniature Marigold. Persistent bloomer. Pretty at all times. Tery useful in the dwarf border $1 / 4$ oz. $50 \mathrm{c} . \ldots \ldots \ldots \ldots \ldots \ldots \ldots \ldots \ldots \ldots \ldots \ldots \ldots$

IEIRBENA. Mammoth. A very fine strain of this well known hardy annual. Constantly in bloom until frost. Sow in the open and transplant 15 inches each way. We offer the following separate colors: White, Blue, Pink, lellow, Purple, Scarlet, Iuricula-eycd Mixed. or Giant Mixed. $1 / 4$ oz. $35 \mathrm{c}$. .

Hybrida Gradiflora Luminosa. A free bloomer of a magnificent salmon pink shade. Strong growing habits and will come true from seed. .....

Etua. The intense colouring of this verbena makes it valuable. A cream vellow eve forms a strong contrast to the geranium red petals. ........

Rose Queel. Finest pink border verbena. Lovely, delicate rose. Im-

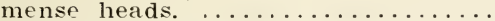

Lucifer. A brilliant flame red of fine texture. A virid flower........... distinct white eye which malies it

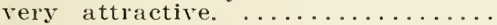

INCA. Well known bedding plant. pure white, lelicata, and wilite with eriason eye. $\ldots \ldots \ldots \ldots \ldots \ldots \ldots \ldots$

VISCARIA. Oculata. A very pretty border annual. Rosy purple with dark eye. 12 inch.

WALLFLOWER. Extra Early Wonder Recommended as a real annual WallRecommended as a real annual Wall-
flower, with all the good points, sizs, flower, with all the good points, sizs,
form and color, of the biennial so much wanted. A real acqusition. . .

Early Single Mixed. A good range of clear colors. A

10.25

$.15 \quad .35$

\section{Annuals for the Rock Garden}

The following is a selected list of annuals which are especially valuable in a rockery. They give a mass of bloom during the summer months when the true alpines have ceased to bloom. For added charm to an alpine garden we recommend these.

$\begin{array}{lll}\text { Abronia } & \text { Ionopsidium } & \text { Portulaca } \\ \text { Alyssum } & \text { Leptosiphon } & \text { Saluitalia } \\ \text { Anagallis } & \text { Lobelia } & \text { Sedum } \\ \text { Candytuft } & \text { Phacelia } & \text { Tagetes } \\ \text { Dianthus } & \text { Phlox } & \text { Vallower }\end{array}$

PACKE' EACH of these 15 varieties $\$ 1.25$ $(\$ 1.75$ value)

\section{ZINNIAS}

Wothin the bast fow years excentional de

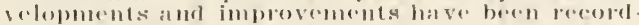
cd with Vimnias. This splendld anmual has becell subjected to many trials and tests with ummsual results being registered in the separation of colors and types.

The seeds which we are offering this yeal ale the product of one of the leading glowers in california. We feel that this serd represents the rery lanest and finest imorovements mad. in zinnia culture.

Kinnias make almilable bedeling plants, ale fine as eut flowers, and in the border they give a splash of vivid color. A finc: and much used annual.

\section{Bodger's Giant Doubles}

This is the best strain of giant Zimnias in cultivation. They are strong growers and bear immense extra double flowers. The colors are very distinct and come quite true from seed with slight variations.

Apricot Orange
Bright Rose
Bufi
Burnt Orange
Crimson
Canary
Purple

Laveuder

Lavender

Salmon

Scarlet

Shrimp l'ink

White

Mixed.

\section{$1 / 4$ oz. 50c}

One Each of the above Zinnias, 13 pkts., $75 c$. Special Mixture. All pink shades. 1/4 . 10.25

\section{Giant Dahlia-Flowered ZINNIAS}

The large size, fullness of petals, finc color range, as well as the good keeping qualities o this flower have all contributed to its popularity. It is easily grown and keeps well when cut. This type is proving a good forcer among the florists.

Seed of this strain of Zinnia has been given official recognition for its superb quality. Highly recomniended.

Crimson Monareh. Largest and best red. Flowers often 8 inches in diameter. $\quad \ldots \ldots \ldots \ldots \ldots \ldots \ldots \ldots \ldots \ldots \ldots$.

Dreasl. A fine deep lavender turning to purple. A new and desirable shade .15 .40

Exquisite. True dahlia form of immense size. Light rose with deep

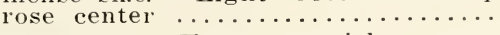

Golden state. Enormous rich orange. $.20 \quad .50$

Illumination. A striking distinct shade

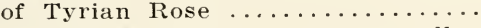

Golden Dawn. Beautiful golden yellow. Comes true to color and type. One of the fine recent introductions from the Pacific Coast.

Lemon Beauty. This is next to Crimson Monarch in size and form. It son Monarch in size and form. It may be described as golden yellow on
brown. Decidedly a pastel shade and should be in every collection. New

Meteor. A rich glowing deep red. Tery large and free bloomer. One of the

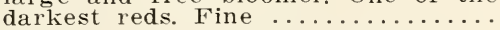

Oriole. One of the most beautiful of its class. Immense orange and gold

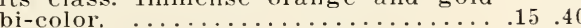

Old Rose. Finest Rose shade ......20 .50

Polar Bear. A very large pure white, The best white vet seen in zinnias. .15.40

Purple Prince. A fine deep purple,

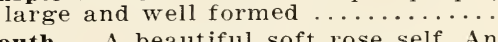

Youth. A beautiful soft rose self. An
extra fine cut flower variety. A disextra fine cut flower variety. A dis-
tinctive color. $\ldots \ldots \ldots \ldots \ldots \ldots \ldots \ldots \ldots .20 .50$

All colors Mixed. $1 / 4$ oz. 75 c .........

Five Packets of Dahlia-Flowered Zinnias. Your choice $60 \mathrm{c}$. 
New Colors in the Giant ROBUS'TA ZINNIAS

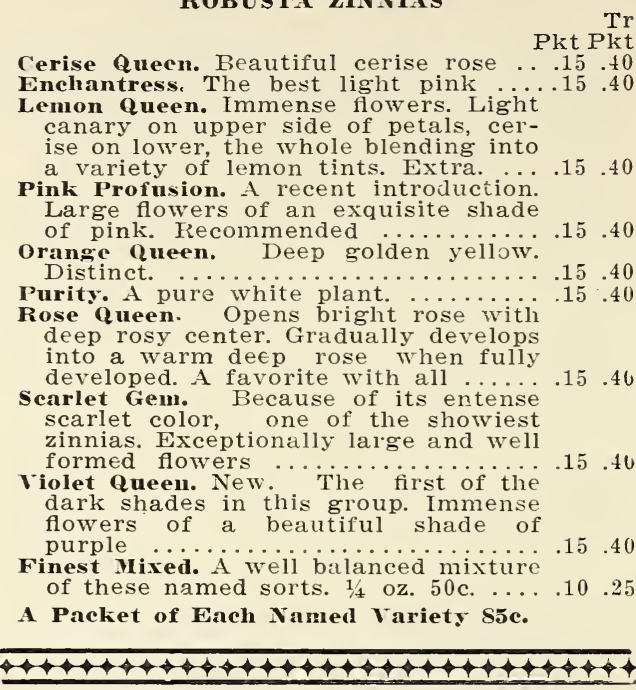

\section{ANNUALS FOR FALL SOWING}

It is not generally known that many of our best and prettiest annuals may be sown in the Fall, and that some of them even do bettr when Fall sown.

Among these are Alyssum, Calendula, Calliopsis, Candytuft, Centaurea cyanus and imperialis, Clarkia, Eschscholtzia, Euphorbia, Godetia, Gypsophila, Hunnemannia, Kochia, Larkspur, Marvel of Peru, Didiscus, Linum, Lupinus, Nemophila, Nigella, Nicotiana, bedding varieties of Petunias, Phlox, Poppies, and Verbena. All the above will be found in splendid variety in our list.

Plants from Fall sown seeds are hardier, with better root systems, and can be transplanted in the cool wet weather of early April. They will bloom earlier, and the blooming season can be greatly lengthened if both Fall and Spring sowings are made.

Care should be taken not to sow too early in the Fall, else the seeds will germinate and seedlings will winter kill. The middle of November is the best time in this section.

\section{Zinnia Novelties}

Curled and Crested. Novel forms and colors with twisted and curled petals. Very pretty and interesting. .........

Elegans Pumila. Dwarf double. Excellent as a bedding variety. A fine mixture of clear bright colors. ........

Gracillima Coccinea. (Red Riding Hood) Small scarlet flowers that are wonderiul in a bed. Makes attractive cut flower for small vases. ........

Haageana. (Mexican Hybrids) A delightful dwarf double in a mixture

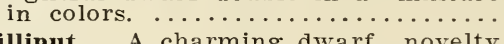

Lilliput. A charming dwarf novelty that is rapidly becoming more populight in a bed or the border, the small, perfectly formed flowers blossom in great profusion. Four distinctive colors. - Canary Yellow, Golden Gen, Salmon Rose, Scarlet Gem, and Mixed. . . . . . . . . . . .

Punila Picotee Delight. Pesult of careful cross hybridizing of the Pumila ed petal's tipped with gold. A mixture of pleasing colors fine for both bedof pleasing colors fine for both bed-
ding and cutting. Recommended. ....

\section{Rare Perennial Seeds}

A small group of rare and unusual alpine and perennial seeds that were not catalogued in the general list. All are choice items, being collected from all over the world. Each $30 \mathrm{c}$ per packet.

GLOBULAIRA nana. A delightful miniature covered with bright blue buttons. 3 inches.

IRIS lacustris. A dwarf light blue. Very rare. 4 inches.

LUPINCS Lyallii. A brilliant dwarf purple from California. Silver foliage. inches.

OMPHALODES Luciliae. Choice alpine with soft blue flowers and glaucous foliage. 6 inches.

SILENE Elizabethae. A rare dwarf with large bright blue flowers. 4 inches.

'THALIC'TRUM alpinum. Charming for the rockery. Fluffy cream-colored flowers. 6 inches.

THYMUS nitidus. Excellent in the border. Masses of purple flowers. 12 inches. 


\title{
PERENNIAL PLANTS
}

$\mathrm{T}$ HE true garden lovers, those who are taking a real interest in the growing of fine flowers, are demanding large sized plants with well established roots. Huntington's plants meet all the requirements of the most critical.

All order's are freshly dug, and all retail order's are filled from the same block of plants from which we dig our wholesale orders. This means that all plants must be up to the high standard set by the professional grower. It assures you of strong healthy plants that will thrive and bloom profusely in your garden.

Our prices especially the twenty five rate approximates wholesale prices, and affords you the opportunity to make an extensive planting at a very moderate cost.

We know that if you once try our plants, either the alpines or the hardy herbaceous varieties, you will find them strong and healthy-plants that will immediately fit into your garden.

Remember-"What will live and grow for us will live and grow for you."

\begin{abstract}
Prices per each, per three, and per dozen by mail postpaid. Orders of twenty five sent by express collect. Not less than six plants at the dozen rate. We are able to send larger plants by express, and if requested will do so in whatever quantity.

Please be certain to give definite shipping instructions and address. If you desire to have shipment by express be sure to give the express office to which the shipment is to be sent.
\end{abstract}

ACHILLEA (Milfoil or Yarrow). One of the prettiest plants in the entire perennial list. Splendid for cutting.

Perry's White. The finest and largest flowered Achillea. The very double flowers often reach one inch in diameter. Each $20 \mathrm{c}$, per three 50c, per doz. \$1.50, per 25 $\$ 2.50$.

Boule de Neige. An improvement on the popular Pearl. In habit this variety is erect instead of spreading, as in Pearl, making a much neater appearance. Each 15c, per three $40 \mathrm{c}$, per dozen $\$ 1.25$, per $25 \$ 2.00$.

Filipendula. Somewhat similar to Millefolium Roseum, but taller, and flower heads are yellow. Easy and free. Good for cutting. Each $20 \mathrm{c}$, per three 50c, per dozen $\$ 1.50$, per $25 \$ 2.50$.

Millefolium Roseum (Rosy Milfoil). Finely cut deep green foliage; pink flowers in dense heads, and borne all summer. 18 inches high. Each $20 \mathrm{c}$, per three 50c, dozen inches high. $\$ 1.50$, per $25 \$ 2.50$.

Tomentosa (Wooly Yarrow). Very dwarf dark green, finely cut foliage. Flat heads of bright yellow, flowers in late June. Fine rock plant. Creeper. Each $20 \mathrm{c}$, per three $50 \mathrm{c}$, dozen $\$ 1.50$, per $25 \$ 2.50$.

\section{ACONitú}

Bicolor, A very pretty blue and white Aconitum. Hardy and very attractive. Recommended. Each $40 \mathrm{c}$, per three $\$ 1.00$, per dozen $\$ 3.00$.

Fisherii. Foliage of deep green, so glossy and thick that the leaves resemble varnished imitations. Deep blue hooded flowers on thick stems in fall. Cut flowers will last for days in water. $12-18$ inches. Very good subject for partial shade. Each $30 \mathrm{c}$ per three 80c, dozen $\$ 2.50$, per $25 \$ 3.75$.

Napellus. Sparks Variets. 5-6 ft. Strong and hardy. A graceful beauty for the back border. Deep blue. Very free. Each 40c, per three $\$ 1.00$, per dozen $\$ 3.00$.

\section{ADENOPHORA}

Lilifolia. This campanula-like purple blue flower will add a touch of bright color to any garden. It is in bloom from June until frost and is very satisfactory and hardy. 18 in. Each $25 \mathrm{c}$, per three $70 \mathrm{c}$, dozen $\$ 2.00$, per $25 \$ 3.00$.

\section{AETHIONEMA}

Persicum. Strong compact dwarf bush-like plant. Slender spikes of light rose flowers. Recommended for rockery. 9 in. Each $30 \mathrm{c}$, per three $75 \mathrm{c}$, per dozen $\$ 2.00$.

\section{Agrostenua}

Coronaria (Rose Campion). Erect, stiff growing plants, with silvery foliage, showy flat flowers in June and July. 2 to 3 ft. Each $15 \mathrm{c}$, per three $40 \mathrm{c}$, per dozen $\$ 1.25$, per 25 $\$ 2.00$.

\section{AJUGA}

Reptans. A useful plant for rockeries or fol ground cover in sun or shade, as under trees where grass will not grow. Large spikes of purplish blue flowers in May. Each $20 \mathrm{c}$ per three $50 \mathrm{c}$, per dozen $\$ 1.50$, per $25 \$ 2.50$

\section{ALYSSUM}

Saxatile Compactum (Basket of Gold). Indis pensable for the border. Produces masses of broad heads of yellow flowers in spring. Each $15 \mathrm{c}$, per three $40 \mathrm{c}$, per dozen $\$ 1.25$, Each $15 \mathrm{c}$, per
per $25 \$ 2.00$.

\section{ANCHUSA}

Italica, Dropmore Variety. One of the most important hardy plants of recent introduction. It is remarkably free-flowering, coming into bloom with or very nearly with Delphinium, and covers itself with pretty blue flowers about 1 inch in diameter. Rather rank in growth, attaining a height of 5 to 6 feet. Strong field roots. Each $20 \mathrm{c}$ per three $50 \mathrm{c}$, dozen $\$ 1.50$, per $25 \$ 2.50$.

Irosotiflora. A handsome dwarf from Rus sia which is ideal in the rockery. Clusters of charming blue flowers resembling large forget-me-nots. The dark green foliage is attractive. 9 in. Each $30 \mathrm{c}$, per three $80 \mathrm{c}$, per dozen $\$ 2.50$, per $25 \$ 4.00$.

\section{ANEMONE}

Japonica (Wind Flower). Large, well opened flowers in soft shades. One of the very latest hardy plants to bloom. Fine for border or cutting. 2 to $3 \mathrm{ft}$.

Queen Charlotte. Semi-double, soft pink.

Whirlwind, Double white.

Hupehensis. A miniature Japanese wind flower in soft mauve-rose. Originally introduced from Central China. A splendid addition to 12 in.

Pulsatilla Lilae. An interesting alpine with lavender blue flowers in early Spring. A gem for the rock garden or border. 9 in Any of above, each $30 \mathrm{c}$, per three $80 \mathrm{c}$, dozen $\$ 2.50$, per $25 \$ 3.75$.

\section{ANTHEMIS (Hardy Marguerite)}

Kelwayii. A very satisfactory summerblooming perennial. Daisy-like flowers of

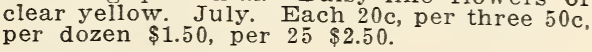




\section{AQUILEGIA}

(Columbine). The distinct attractive clearcut foliage and delicate arrangement of colors in the flowers of Columbine make it a showy and desirable hardy garden plant; especially suitable for rockwork, at the base of foundation walls and under trees. May, of foundation walls ald under trees. May, June. All varieties, unless noted, each
per three $50 \mathrm{c}$, dozen $\$ 1.50$, per $25 \$ 2.50$.

Alpina Coerulea. Deep blue, large flowers.

Alpina Superba. Deep blue and white. Both these Alpine varieties are very hardy and strong, and will stand up under conditions that would kill the long spurred sorts.

Chrysantha. The Golden Spurred Columbine.

Chrysantha Alba. Long-spurred, white.

Coerulea. The dainty Rocky Mountain Columbine; blue and white.

Long-spurred Hybrids, Mrs. Seott Elliott's Strain. Large, open flowers of mauve, straw, vellow, rose, shell-pink, lavendel. pale blue, purple, etc. Splendid for cutting. We consider this the best strain in cultivation.

Selected Pink Shades. These ale selected plants, taken while in bloom from a seed block of Mrs. Scott Elliott. Colors ringe from pale shell pink to deep rose with yellow underlay. Wach $35 \mathrm{c}$, per three $\$ 1.00$ dozen $\$ 3.00$, per $25 \$ 5.00$.

\section{A IRAIIS}

Alpina (Rock Cress). A fine dependable rock garden plant. Sheets of clear white flowel. in early spring. The foliage remains at tractive and orderly all summer. Dwalf. Each $20 \mathrm{c}$, per three $50 \mathrm{c}$, per dozen $\$ 1.50$, per

\section{ARMERIA}

Attractive dwarf plants that will succeed in any soil, forming evergreen tufts of bright green foliage, from which flowers appear in dense heads on stiff wiry stems about 9 inches high. Very effective in rockery or border. June, July. Each $20 \mathrm{c}$,
per three $50 \mathrm{c}$, per dozen $\$ 1.50$, per $25 \$ 2.50$.

Laucheana. One of the best. Brilliant rose. Desirable.

Iaritima Splemdens. Soft pink. Excellent in the border.

Bees Ruby. Much larger and taller than the type. 2 in . flower's on $2 \mathrm{ft}$. stems. From deep rose to shell pink. Each $40 \mathrm{c}$, per 3 $\$ 1.00$, doz. $\$ 3.00$.

\section{A R'TEMISIA}

Lactiflora. Glows 4 to $4^{1 / 2}$ fect tall; darl green, finely cut foliage. In bloom with us from August 15 to October 1, and simply covered with many-branched panicles of fragrant white flowers. Fine for cutting with other flowers or for use alone in large vases. A fine perennial plant of recent introduction. Field clumps. Each 20c, per three $50 \mathrm{c}$, per dozen $\$ 1.50$, per $25 \$ 2.50$.

Silver King. One of the newer introductions. A fine hardy novelty for winter bouquets or for the border. The attractive foliage is frosted silver, mixing splendidly with the darker green of the border, or with dried darker green of the border, or with dried
winter flowers. $20 \mathrm{c}$ each, per three $70 \mathrm{c}$, dozen $\$ 2.00$, per $25 \$ 3.00$.

\section{AsCLEPIAS (Butterily Weed)}

Tuberosa. Flowers brilliant orange on stems 2 feet high. One of the most gorgeous of Amelican flowers and should be in every collection. Each 20c, per three 50c, dozen $\$ 1.50$, per $25 \$ 2.50$

\section{ASTER}

Michaelmas Daisies. Anong the showiest of our late-flowering hardy plants. Most of them are native of the northern and middle states, and will grow freely anywhere. Price, except where noted eacl $20 \mathrm{c}$, per three $50 \mathrm{c}$, dozen $\$ 1.50$, per $25 \$ 2.50$.

Blue Gem. Double Rich Blue. Same price as Mrs. F. W. Raynor.

Climax, A new variety with light lavenderblue flowers, from late August until Oc tober 5 feet.

Climax white. Same as above except color.
Elta. Double. Pale Lilac. New. Same price as Mrs. F. W. Raynor.

Feltham Blue. The finest blue Aster. Pale sky-blue flowers, with large yellow centers, simply cover the plant. $2 \frac{1}{2}$ feet.

Japanese, Double. Small white blooms with a brilliant yellow center. As double as Achillea, Boule de Neige. Fine for cutting. Each $30 \mathrm{c}$, pel three $80 \mathrm{c}$, dozen $\$ 2.50$, per $25 \$ 3.75$.

Mauve Cushion. Very dwarf; free blooming. Delicate soft mauve. Extra-fine late-blooming bolder plant.

IIrs. F. WV, Rayuor (Nova Anglae Type). Nearest red of any hardy aster. Not a new variety, but very scarce. Each $30 c$, per three $80 \mathrm{c}$, dozen $\$ 2.50$, per $25 \$ 3.75$.

Novae-Anglae. . Bright . purple; extra-large flower's. 4 feet.

Novae-Anglae Rosea. A fine rosy red shade, tall and strong grower.

Tartarica. Purple; a most showy, large bloom. 4 feet.

St. Egwin. About the height and as formal in glowth as the well-known Fire plant. Foliage deep green. In September the plant is covered with flat, open flowers of dul pink. One of our most useful border perennials. Award of Merit, Royal Horticultural Society, London.

Collection of 12 Asters. One of each named variety-\$1.75.

\section{IS'TILBE}

Hybriala Garuet. An excellent hardy plant for a shady place in the border. Feathery spikes of rich crinison. Foliage very attractive. Serves as an acceptable cut flower. 2 feet. Blooms in June and lasts well. Each $60 \mathrm{c}$, per three $\$ 1.50$, per dozen $\$ 5.00$.

Hybrida Gloria. Same growth and price as above. A choice pink of recent introduction. Highly recommended for moist situations.

\section{IUBRE'TIA}

Hybrial Gramdiflora. One of the finest rock plants in the list. Forms compact clumps of deep violet and lavender flowers during early Spring and lasting well into the summer. Colorful gems for the rockery. In pots only. Each $30 \mathrm{c}$, per three $80 \mathrm{c}$, per dozen $\$ 2.00$.

\section{IZA LEA}

Mollis (Japanese Azalea). These are grown from selected seeds. Wintered outside for four years in this cold climate. They should prove hardy even into Canada. The color's which are brilliant in the spring, range from glowing orange to pink and a bright yellow. One of the finest, and most colorful shrubs. Give woodsloam and partial shade and they will thrive. Shipped by expless with the roots balled and burlaped. 12 to 15 inches $75 \mathrm{c}, 18$ to 24 inches $\$ 1.50$.

\section{A P'IISIA}

Australis (False Indigo.) A strong growing bushy plant with attractive, deep green foliage. Forms a large clump, with spikes of deep blue flowers in June. Very hardy and easy. 2 to 3 feet. Each $20 \mathrm{c}$, per three $50 \mathrm{c}$, dozen $\$ 1.50$, per $25 \$ 2.50$.

\section{BE'TONICA}

Grandiflora (Betony). Close growing foliage Bright rose flowers in spikes. Attractive. Each $20 \mathrm{c}$, per three $50 \mathrm{c}$, per doz. $\$ 1.50$.

\section{Bocconia}

Corlata. A noble. hardy perennial, beautiful in foliage and flower. Being lather heavy, it is especially suitable with shrubbery in borders or in bold groups. It thrives any. where, and attains a height of 6 to 8 feet. Creamy white flowers, in terminal panicles, borne in July and August. Each 20c, per three $50 \mathrm{c}$, dozen $\$ 1.50$, per $25 \$ 2.50$.

BOI,TONIA. (False Chamomile). Large, single aster like flowers, in bloom during summer and autumn. Its thousands of flowers open at one time, producing a very showy effect. Useful for cutting or decoration. Fieldgrown clumps, each $20 \mathrm{c}$, per three $50 \mathrm{c}$, doz $\$ 1.50$, per $25 \$ 2.50$.

Asteroides. Pure white: very effective. 5 to 7 feet.

Latisquamac. Pink, slightly tinged lavender. 4 to 6 feet. 


\section{(B)II)ISYIAN}

Variabilis Magniliea. A finc new addition to oul summer-llowering shrulss. lilooms in terminal spikes, deep lilac in eolor, and ver,

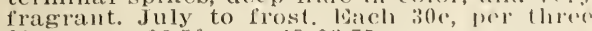
$80 \mathrm{c}$, dozen $\$ 2.50$, per $25 \$ 3.75$.

Farquhari (New). A low slowing, spreidins shrub with rich green foliage and silver lo verse. Has long, graceful racemes of brimb

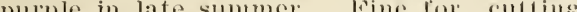
strons plants. Wacli 500, per there $\$ 1.25,001$ dozen $\$ .00$.

\section{CAMPANULA}

Carpatiea (Carpathian Harebell). A pretty compact species, not exeeding 8 inches high. Flowers 1 inch in diameter. Hiue of white. July. Each 20c, per three 50e, doz. $\$ 1.50$, per $25 \$ 2.50$.

Medium (Canterbury Bells,) Blooms in July; heiont 2 to 3 feet. Three colors, liose, height 2 to rach dozen $\$ 1.50$, per $25 \$ 2.50$.

('alycanthoma (Cup and saucer Canterbury Bells.) Same as Medium except that each flower is set in a small saucer. Rose, White, Blue. Each $20 \mathrm{c}$, per three $50 \mathrm{c}$, doz. $\$ 1.50$ per $\$ 2.50$.

Persicifolia (Peach Bells). Grows 11/2 to 2 feet high. Salver-shaped flowers. Two colors. Blue or White. July, August. Each 25c. pei three 70c, dozen $\$ 2.00$, per $25 \$ 3.00$

Pyramidalis (Chimney Eellfower). Very conspicious; 4 to 5 feet high. Salver-shaped blue flowers borne profusely in September. Each $25 \mathrm{c}$, per three $70 \mathrm{c}$, dozen $\$ 2.00$, per 25 . $\$ 3.00$.

Rotundifolia. (Blue Bells of Scotland.) From June through August this attractive plant is covered with bright blue cup-shaped flowers. Fine for the rockery. 8 inches high. Each $25 \mathrm{c}$, per three $70 \approx$, per dozen $\$ 2.50$, per $25 \$ 3.50$.

\section{CARYATION}

One of the favorites in the perennial border. Bright grey, green foliage with large brilliant colored flowers. These serve nicely as cut flowers. A large majority are strong full doubles. The hardiest Carnation.

Greuadin. White, Scarlet, Rose, Maroon, or Mixed. Wach $20 \mathrm{c}$, per three $50 \mathrm{c}$, per dozen $\$ 1.50$, per $25 \$ 2.50$

\section{CASSIA}

Marylandica. A bushy plant growing from 3 to 4 feet high. Large panicles of bright yellow flowers in July and August. $\mathrm{Each}$ $25 \mathrm{c}$, per three $70 \mathrm{c}$, dozen $\$ 2.00$, per $25, \$ 3.00$.

\section{CATANA NCHI}

Coerulea. Low growing plants, with pretty flowers about $1 \frac{1}{2}$ inches across, on clean, stiff stems. Fine for cutting. This belongs to the everlastings. Each $25 \mathrm{c}$, per three $70 \mathrm{c}$ dozen $\$ 2.00$, per $25 \$ 3.00$

\section{CEN'TAUREA}

Deaibata. A very pretty perennial which is becoming increasingly popular. The rosy lavender flowers of large size cover the plant throughout the month of June. Desirable in the border. 2 feet. Each $25 \mathrm{c}$, per three $70 \mathrm{c}$, per dozen $\$ 2.00$, per $25 \$ 3.00$.

Maeroecphala. Large thistle-like heads of bright yellow flowers. Useful for cutting and for tall effects in the hardy border. July to September. 3 to 4 feet. Each 30 c, per three $70 \mathrm{c}$, dozen $\$ 2,00$

Montana. Fine border plant, with large cornflower-blue flowers in August and September. 2 feet. Each $20 \mathrm{c}$, per three $50 \mathrm{c}$, dozen $\$ 1.50$, per $25 \$ 2.50$.

CERASTIUM (Snow-in-Summer)

Tomentosum. Pure white flowers in May arrd June, 6 inches. Each $20 \mathrm{c}$, per three $50 \mathrm{c}$, dozen $\$ 1.50$, per $25 \$ 2.50$.

CHELONE (Shell Flower).

Lyonii. Heads of purplish rose flowers. Each $30 \mathrm{c}$, per three $70 \mathrm{c}$, dozen $\$ 2.00$, per $25 \$ 2.50$.

\section{CHIERANTHUS}

Allioni. (Siberian Wallfower). An excellent rock plant. Brilliant. orange flowers blooming profusely in the Spring. Really a biennial as it many times blooms itself to death. Each $20 \mathrm{c}$, per three $50 \mathrm{c}$, per dozen $\$ 1.50$, per $25 \$ 2.50$.

\section{CHRYSAN'THEMUMS}

This list of "mumms" is solecterl from thowe variction which we eomsides lo be the best of their type and perfecetly hatrdy. 'The hardincess of a clorysanthrmmom is of extreme: fmportanes. and these mums, coupled with their pieloness of color are hardy.

ive would recommend llat you divide clorysallhemums every other year at least. A small division, planted in the spring, will flowive iil the atutuimm

These are all field grown clumus.

Alice Howell. Yellow strorgly oveleast with bronze.

Hva. Dwate growing variety. elautiful shade of pink. Excellent for border.

Golden cucen. Brilliant yelluw flowers on stately stems.

Hills of suow. Dwarf. Showers of small white blossoms.

Indian. Of the true Autumn color. Rich Indian Red.

I'Argentalis. Coppery red tipped light brown. Recommended.

Little Itob. A profusion of bionze buttons. Desirable.

Marie Antoinetre. A deep rose. A dependable variety.

Old Honested. Bright pink silver. Pretty and unusual.

White Beauty. A large early white delicately shaded with a rich pink. A free bloomer. All Inms Wach 20 , per three 50e, per dozen
$\$ 1.50$, per 25 \$2.50. One of each variety of Muins $\$ 1.60$.

\section{CIMICIFUGIA}

Raceniosa. A fine native perennial with spikes of pure white flowers in July and August A fine plant for naturalizing iu woods. Each $25 \mathrm{c}$, per three $70 \mathrm{c}$, dozen $\$ 2.00$.

\section{COREOI'SIS}

Lanceolata Grandiflora. The perfected strain of a long popular hardy plant. Flowers ar. rich golden yellow, borne in great profusion nearly the entire summer. Each $15 \mathrm{c}$, per three $10 \mathrm{c}$, dozen $\$ 1.00$, per $25 \$ 2.00$.

Verieillata. An old garden favorite, with finely cut, very ornamental foliage, symmetrical as Kochia, 18 inches tall. Yellow flowers in bloom from June to frost. Eacr $25 \mathrm{c}$, per three $70 \mathrm{c}$, dozen $\$ 2.00$, per $25 \$ 3.00$.

\section{CRUCIANELLA}

Stylosa. These bright pink ball-shaped flowers make an attractive showing in the rockery. A desirable Alpine. 6". Each 25c, per three $70 \mathrm{c}$, dozen $\$ 2.00$, per $25 \$ 3.00$.

\section{DELPHINIUMS}

The charm of English gardens comes from the stately Delphinium. The long graceful spike, in many shades of blue are indispensable. These strong field grown plants will give you a mass of bright clear color.

Chinensis. Fine stems and deeply cleft foliage; flowers of dark, brilliant blue. 18 inches. Jach $20 \mathrm{c}$, per three $50 \mathrm{c}$, dozen $\$ 1.50$, per $25 \$ 2.50$

Belladonna. The finest and most continuous bloomer of all, never being out of flower from the end of June till cut down by frost. Clear, turquoise-blue. When flowers fade the stems should be cut off to insure continuous blooms. Strong field roots. Each $15 \mathrm{c}$, per three $40 \mathrm{c}$, dozen $\$ 1.25$, per $25 \$ 2.00$.

Bellamosa. This is so superior to Formosa that we have dropped the latter. A sport from Belladonna, pure dark blue, with all the ever-blooming qualities of Belladonna. Each 20c, per three 50c, dozen $\$ 1.50$, per 25 $\$ 2.50$.

English Hybrids of extra quality. A superfine strain, extra large flowering, contain ing all shades known to delphiniums, and many fine doubles. Each 25, per three $70 \mathrm{c}$ dozen $\$ 2.00$, per $25 \$ 3.00$.

Hollyhoek Strain. Grown from seeds used in the trials of the best of English Euro pean and American strains. Large singles and superb doubles of exquisite coloring. Considered the best strain of Delphinium. Each $35 \mathrm{c}$, per three $90 \mathrm{c}$, per dozen $\$ 2.50$. 


\section{DAPHNE}

Cneorum (Garland Flower). Dwarf almost prostrate evergreen shrub. Especially fin for the rock garden. Blossoms are bright pink, and fragrance so delightful as to be compared by many to the Trailing Arbutus. Blooms in early spring and again in September. Each $\$ 1.50$, per three $\$ 3.50$.

\section{DESMODIUM}

Penduliflorum. (Sweet Pea Shrub). A true herbaceous plant, but by fall it has made bushy plant from 3 to 5 feet tall. Simpl) covered in September and October witl. wine-red, pea-shaped bloom. Very ornamental at all times. Each $30 \mathrm{c}$, per three $80 \mathrm{e}$ dozen $\$ 3.00$, per $25 \$ 5.00$

\section{DIANTHUS}

\section{HARDY GARDEN PINIKS}

Without the spicy fragrance of the hardy Pinks a garden is incomplete. Their perfect form and rich coloring make them great favorites for summer bouquets. June. Strong field plants. Each 20c, per three $50 \mathrm{c}$, dozen $\$ 1.50$, per $\underset{25}{\text { plants. }} \$ 2.50$.

Deltoides. A very pretty alpine plant, with cron folia and flat pink flowers in June and July. Especially suitable for rock gardens.

Deltoides Major Stearns Variety. A fine, new English introduction. A gem for the rock garden. Brown tinted foliage, and bright crimson flowers which cover the plant. Very desirable. Each 25c, per three 70c, dozen $\$ 2.00$, per $25 \$ 3.00$.

Double Scotch Pink, Little Dorrit (Hunting. ton). Compared with Her Majesty, flower is not quite as large, with a touch of bright crimson in center. Plant is neat and orderly, without the spreading habit of Her Majesty. Period of bloom is much longer. Its hardiness, neat habit, and dwarf growth, coupled with the persistent blooming qualities make it an ideal dwarf border for the formal it an ideal dwarf border for the formal hardy white for the rock garden. Each $25 \mathrm{c}$ per three $70 \mathrm{c}$, dozen $\$ 2.00$, per $25 \$ 3.00$

Essex Witch. Neat tufts of blue green foliage which in June are covered with very pretty fragrant double rose flowers of a fine quality. Dwarf growing. Excellent in the border or the rockery. Recommended. Each $20 \mathrm{c}$, per three $50 \mathrm{c}$, per dozen $\$ 1.50$, per 25 $\$ 2.50$.

\section{DIAN'THUS BARBATUS (Sweet William),}

Johnson's Giant., The finest of the Sweet Williams; immense flowers in gorgeous shades. Each $20 \mathrm{c}$, per three $50 \mathrm{c}$, dozen $\$ 1.50$, per 25 $\$ 2.50$.

Newport Pink, Double White or Scarlet Beauty Each $20 \mathrm{c}$, per three $50 \mathrm{c}$, dozen $\$ 1.50$.

Iatifolius Atrococeineus. (Everyblooming Sweet William). In bloom from early June to frost. Brilliant crimson; double; fine for bedding or cutting. Each $20 \mathrm{c}$, three $50 \mathrm{c}$, dozen $\$ 1.50$, per $25 \$ 2.50$.

\section{DICENTRA (Dielytra).}

Eximea (Plumy Bleeding-Heart). A dwarf growing sort, with beautiful finely cut foliage and showy racemes of pretty pink flowers throughout the season. Too much cannot be said for this fine border plant as it is equally at home in full shade or sun and perfectly hardy everywhere. Bailey's Encyclopedia of American Horticulture says in description; "The handsomest foliage of any border plant in the entire collection." Strong field roots. Each 30, per three $80 \mathrm{c}$, dozen $\$ 3.00$, per $25 \$ 4.25$.

spectabilis. The "Bleeding Heart" of grandmother's garden. This has been scarce for some years, but we can furnish now for, each $50 \mathrm{c}$, per three $\$ 1.25$, dozen $\$ 4.00$, per

\section{DICTAMNUS (Gas Plant)}

Fraxinella Rubra. An old garden favorite which has a strong smell of lemon, and which will give a flash of light when a lighted match is held under the flowercluster and near the main stem. Frawerfoliage. Spikes of curious red flowers. Each $40 \mathrm{c}$, per three $\$ 1.00$, dozen $\$ 3.50$.

Fraxinella Alba. White flowers. Each $40 \mathrm{c}$, per three $\$ 1.00$, dozen $\$ 3.50$.

\section{DIGITALIS}

Foxmlove. Old-fashioned plants which furnish a grand display of flowers in immense spikes in July and August. Strong plants, each $20 \mathrm{c}$, per three $50 \mathrm{c}$, dozen $\$ 1.50$, per 25 $\$ 2.50$.

Alba. White.

Rosea. Rose.

Purpurea. Purple.

Grandiflora. Yellow.

The Shirley, Mixed colors in a strain said to be much larger and better than Gloxinaeflora. We found some better colors, a few larger flowers and on the whole, a little better than the old form above. Each $25 \mathrm{c}$ per three $70 \mathrm{c}$, per dozen $\$ 1.00$, per $25 \$ 3.00$.

\section{DORONICUM}

Excelsum. One of the earliest spring bloomers. Sunflower-like flowers of yellow, on long, clean stems. Splenãid for cutting or for the border. Each $50 \mathrm{c}$, per three $\$ 1.25$, per dozen $\$ 1.50$.

\section{EIRY NGIUM}

Sea Holly Handsome ornamental plants, 2 to 3 feet tall, with stiff, spiky leaves. Flowers of light blue from July to September. Very useful for dried bouquets.

Amethystinum. Finely cut, stiff, glossy foliage, small flowers of amethyst blue. Each $20 \mathrm{c}$, per three 50 , dozen $\$ 1.50$, per $25 \$ 2.50$.

Planum. Larger in every way than Amethystinum. Each 20c, per three $50 \mathrm{c}$, dozen $\$ 1.50$ per $25 \$ 2.50$.

\section{EUPATORIUM}

Coelestinum. Simply covered with blue ageratum-like flowers in August and September. 2 feet. Each $20 \mathrm{c}$, per three $50 \mathrm{c}$, dozen $\$ 1.50$ per $25 \$ 2.50$.

Ageratoides (Thoroughwort). A useful border plant. Dense terminal heads of white flow ers. Grows well in shade. Each 20c, pe. three $50 \mathrm{c}$, dozen $\$ 1.50$, per $25 \$ 2.50$.

\section{EUPHORBIA}

Corollata. A wide-branching, low-growing plant, with very wiry stems, literally covered with fine white flowers from June to August. Invaluable for cutting. Each $20 \mathrm{c}$ per three $50 \mathrm{c}$, dozen $\$ 1.50$, per $25, \$ 2.50$.

\section{FESTUCA}

Glauca. A handsome dwarf, ideal for the rockery. Small spiked tufts of blue green foliage. Gives a bright touch to the rockery. Fine for neat border. Six inches tall. Each $20 \mathrm{c}$, per three $50 \mathrm{c}$, per dozen $\$ 1.50$, per $25 \$ 2.50$.

FUNRIA (Plantain Lily).

Iedia Variegata. Large deep green leares striped yellow; a splendid dwarf border plant. Each $20 \mathrm{c}$, per three $50 \mathrm{c}$, dozen $\$ 1.50$, per $25 \$ 2.50$

Lanceolata (Day Lily). Deep, glossy greer foliage; free blooming; especially useful for shady places. Each $20 \mathrm{c}$, per three $50 \mathrm{c}$, dozen $\$ 1.50$, per $25 \$ 2.50$.

Subcordata Grandifora. Pure white, lilyshaped flowers in August. Excellent for bedding. Foliage especially attractive. Eacl $30 \mathrm{c}$, per three $80 \mathrm{c}$, dozen $\$ 2.50$, per $25 \$ 3.75$.

Fortuneii Gigantea. The foliage of this plant is very attractive being steel blue. We feel confident that it will become a very popular border plant. Flowers light lavender. Each $25 \mathrm{c}$, per three $70 \mathrm{c}$, dozen $\$ 2.00$, per $25 \$ 3.00$. 
GAII,IIBI) (HIanket Flower).

Grandillora. Makes a most gorgeous display Flowers 3 in. in diameter on 2 -foot stems. Flowers 3 in. in diameter on $A$ hard center of maroon is thickly bordried
by petals of orange and yellow, strikingly ringed by circles of crimson, red and maroon Will thrive in poor soil, and a constant slow is assured from June till frost. Wich $20 \mathrm{c}$, per three $50 \mathrm{c}$, per dozen $\$ 1.50$, per $25 \$ 2.50$

Portola Hybrias. An improved strain of large flowered lybrids. Brilliant colors and immense semi-double blooms of recommended nierit. Each $30 \mathrm{c}$, per three $75 \mathrm{c}$, per dozen $\$ 2.00$.

GALEGA

Oriciunis mana rosea. An attractive dwarf witl bright foliage and clear pink pea shaped flowers. Equally useful either in the rockery or the border. Each 20c, per three $50 \mathrm{c}$, per dozen $\$ 1.50$.

\section{GEN'TIANA}

Audrewsii (Closed Gentian). A quite rule native plant. The tightly closed flowers are borne in clusters on terminal stems. Intense bright blue. Does best in moist places, rather heavy soil and will stand more than partial shade. Each $25 \mathrm{c}$, per three $70 \mathrm{c}$, per dozen $\$ 2.00$

\section{GEIRANIUM}

Sanguineum. A low-growing plant with pretty cut foliage, and flat flowers of bright crimson Our native Geranium. Each $25 \mathrm{c}$, per three $70 \mathrm{c}$, dozen $\$ 2.00$

\section{GEUM}

Mrs. Bradshav. A fine perennial with double scarlet flowers on erect fifteen-inch graceful stems. Foliage is finely cut and very attractive. Beautiful in either the rockery or border. Each $25 \mathrm{c}$, per three $70 \mathrm{c}$, per dozen $\$ 2.00$, per $25 \$ 3.00$

Lady Statheden. A large golden yellow counterpart of Mrs. Bradshaw. A more recent introduction. Recommended. Same price as above.

\section{GLOBULARIA}

Cordifolia. An excellent alpine. The flower, a globe of bright blue, rises about eight inches above the rosettes of evergreen leaves. Blooms the latter part of May. Perfectly hardy. A splendid addition to the rock garden. Recommended. Each $25 \mathrm{c}$, per three $70 \mathrm{c}$, per dozen $\$ 2.00$

\section{GYPSOPHILA}

Baby's Breath. A beautiful old-fashioned hardy perennial. Excellent for cutting with other flowers.

Paniculata. Minute pure white flowers. Two to 3 feet. Each $15 \mathrm{c}$, per three $40 \mathrm{c}$, dozen $\$ 1.25$, per $25 \$ 2.00$.

Bristol Fairy. A splendid introduction of high merit. Profuse in its bloom, the panicles are much larger, and the individual blossom is bigger. Delightful in the border and as a cut flower it is unrivaled. All grafted 100 per cent double stock. Each $75 \mathrm{c}$, per three $\$ 1.75$.

\section{HELENIUM}

Riverton Gem. Flowers brilliant old-gold, suffused terra-cotta, changing as they mature to wallflower red. August and September. Each $25 \mathrm{c}$, per three $70 \mathrm{c}$, dozen $\$ 2.00$ per $25 \$ 3.00$.

\section{HWLINN'HHAMUM (Sun Rose)}

Mutabile Mixed. Low glowing evergreen plants, which are well adapted for borders rockeries, or sunny banks. Mixed paste shades. Each $25 \mathrm{c}$, per three $70 \mathrm{c}$, dozen $\$ 2.00$.

\section{HELIAN'THUS (Sumflower)} Very profitable for summer cutting anc massive display.

Mollis Grandiflora. Light lemon-yellow; large single. Foliage quite hairy. 4 feet. Each $20 \mathrm{c}$, per three $50 \mathrm{c}$, dozen $\$ 1.50$, per $25 \$ 2.50$

Multiflorus fl. pl. Large, double yellow blooms, 4 feet. Each $20 c$, per three $50 c$, per dozen, $\$ 1.50$, per $25 \$ 2.50$.

Orgyalis. Single lemon-yellow flowers in abundance. 6 to 8 feet tall; branches neal sumnit; foliage dense and gracefully drooping. Each $25 \mathrm{c}$, per three $70 \mathrm{c}$, dozen $\$ 2.50$, per $25 \$ 300$
HICLIOLSIS (1)range Sunthower)

rofeheriana. Frotty daisy-like: flowers, orangr yellow, with a jeramidal conter of darke. shades leacle $20 \mathrm{c}$, pel three $50 \mathrm{c}$, pro dozen $\$ 1.50$, pe:r $25 \$ 2.50$

Scabra lixcelsa. A now double-flowering form. growing about 30 inches tall and frec. ly baring double golden yellow flowers, closely resembling a Vinnis. July and $\Lambda$ ug ust. Fine for cutting. bach $20 \mathrm{c}$, per throe $50 \mathrm{c}$, dozen $\$ 1.50$, por $25 \$ 2.50$

\section{IIHMIROCALIS}

Ia. Lils. Very effective in clumps and masses: numerous panicles of oladnge ant yellow lily-like flowers protruding high above the grass-like foliage.

INw:uso Ir. IP. This fine variety resembles i giant double Tiger lily. A beauty as an individual plant and exceptionally brilliant when in a group. Very double orange yellow. Each 30c, per three 80c, dozen $\$ 2.50$, per $25 \$ 3.75$.

Flava. The true old Lemon Lily. Now very scarce. Strong plants. Each 25c, per three $70 \mathrm{c}$, per doz $\$ 2.50$, per $25 \$ 3.75$.

Middemdorfiii. Deep golden yellow flowers June and July. $1 \frac{1 / 2}{2}$ to 2 feet. Each $20 \mathrm{c}$, per three $50 \mathrm{c}$, dozen $\$ 1.50$, per $25 \$ 2.50$.

Dr. Regal. Listed by Holland growers as "late"; with us it is earliest of all to bloom. coming before Decoration Day. Award of merit, Royal Horticultural Society, London. Each $25 \mathrm{c}$, per three $70 \mathrm{c}$, dozen $\$ 2.30$, per 25 $\$ 3.00$.

'Thumberail. Latest blooming of the Lemon Lilies. Each $20 \mathrm{c}$, per three $50 \mathrm{c}$, dozen $\$ 1.50$.

\section{HEPATICA}

Triloba (Liver Leaf). Pretty native spring flowering plant. For a shady spot in the rock garden, this dainty lavender gem is ideal. Each $20 \mathrm{c}$, per three $50 \mathrm{c}$, dozen $\$ 1.50$, $\mathrm{p} \in \mathrm{r} 25 \$ 2.50$.

\section{HEUCHERA}

Brizoides (Coral Bells). The hardiest of the Heucheras. Tiny bells of soft coral-pink on long. slender, wiry stems; in bloom from June till fall. Fine for cutting. Each $30 \mathrm{c}$, per three $80 \mathrm{c}$, dozen $\$ 2.50$, per $25 \$ 3.75$.

Sauguinea. A most brilliant pleasing coral red. When used in the herbaceous garden it gives a touch of color throughout most of the summer. A fine addition. Each $30 \mathrm{c}$, per three $80 \mathrm{c}$, per dozen $\$ 2.50$.

\section{HOLLYHOCK}

Chater's Doubles. Nothing will ever take the place of this favorite in the old fashioned garden. A group of these in the back border, against a hedge or wall will give you a bright display of exquisite color. The double flowers are in Crimson-yellowwhite-pink-maroon. Each 20c, per three $50 \mathrm{c}$, dozen $\$ 1.50$, per $25 \$ 2.50$.

Three of each color-Fifteen plants-\$2.00.

\section{IBERIS (Hardy Candytuft)}

Sempervirens. Dark green evergreen foliage, completely hidden in April and May with heads of white flowers, 10 inches. Each $20 \mathrm{c}$ per three $50 \mathrm{c}$, per dozen $\$ 1.50$, per $25 \$ 2.50$

Gibraltarica. Larger and more persistent bloomer than above. Pale lavender pink. Each 20c, per three $50 \mathrm{c}$, dozen $\$ 1.50$.

\section{IRIS}

Iris Germaniea. German Iris is the true Fleur-de-lis, the national flower of France. All varieties are perfectly hardy, thrive anywhere, grow and bloom luxuriantly. Plant. well established produce from 50 to 100 spikes of bloom; some are deliciously fragrant and all are fine for cutting. Fullgrown plants, each $15 \mathrm{c}$. per three $40 \mathrm{c}$, dozen $\$ 1.25$, per $25 \$ 2.00$, unless otherwise noted.

Ambassadeur. Standard smoky bronze, falls dark velvet maroon. The finest dark colored Iris to date. Am. Iris Soc. scores this Iris 9.4. Ideal grower and very free. Each $50 \mathrm{c}$ per three $\$ 1.25$, per dozen $\$ 4.00$.

Caprice. Immense blooms; solid violet-blue. Each $25 \mathrm{c}$, three $70 \mathrm{c}$, dozen $\$ 2.00,25 \$ 3.00$. 
IRIS (Continued)

Ed Michel. Standards rosy mauvé; falls dee mauve. Large, handsome, distinct and very rare.

Iris King. Standards lemon-yellow; falls deep satiny brown with broad margin of golden yellow. Tery large and rank grower.

Isolene. Standards pale lavender; falls light purple overlaid brown; beard yellow. Each $30 \mathrm{c}$, per three $80 \mathrm{c}$ dozen $\$ 2.50$.

Lohengrin. Standards and falls uniform shade of cattleya rose. Very large.

Lent A. Williamson. The American Iris Society gives this Iris the highest rating of any in cultivation, scoring it 9.6 out of a possible 10. Standards lavender-violet, falls velvety royal purple. Flowers of gigantic size, tall ( 12 inches) and strong grower, and extra, free. Each $30 \mathrm{c}$, per three 80. dozen $\$ 2.50$

Ime. Chereau. Very delicate and distinct, white, edged blue.

Irs. Alan Gray. Uniform delicate pale rose. This Iris often blooms in the fall. One of the best pinks. Each $30 \mathrm{c}$, per three $80 \mathrm{c}$, dozen $\$ 3.00$.

Irs. Neubronner. Deep golden yellow without marks or shadings; very fine.

Nibelungen. Falls violet, standards fawn. A handsome variety. Each $25 \mathrm{c}$, per three $70 \mathrm{c}$, dozen $\$ 2.00$

Pallida Dalmatica Princess Beatrice. The true type. Often called the "Queen of Iris" and rightfully for no other Iris can rival the delicate shades of lavender and light blue of this one. It is a free grower and very fragrant. Fine. Special price, each $25 \mathrm{c}$, per three $70 \mathrm{c}$, dozen $\$ 2.00$, per $25 \$ 2.75$.

Rhein Nixe. Standards pure white; falls deep violet-blue with narrow white margin. A striking combination, finest for cutting. Each 20c, per three $50 \mathrm{c}$, dozen $\$ 1.50$.

Rose Unique. Standards and falls bright violet-rose. Nearest approach to a pink Iris. Very early. Each $40 \mathrm{c}$, per three $\$ 1.00$, dozen $\$ 4.00$.

Victorine. Standards white; falls mottled violet. A sharp contrast; beautiful and rare. Each $25 \mathrm{c}$, per three $70 \mathrm{c}$, dozen $\$ 2.00$.

Wyomissing. Standards rosy white; falls deep rose, shading to flesh. Fach $25 \mathrm{c}$, per three $70 \mathrm{c}$, dozen $\$ 2.00$.

Windham. Standards light rose, falls deeper shade of same color. Tery good rose color effect. Each $25 \mathrm{c}$, dozen $\$ 2.50$.

IRIS KAEMPFERI (Japanese Iris)

Finest of all the Iris family. The flowers are of immense size-from 6 to 8 inches in diameter-and of the most beautiful and delicate shades. Each 25c, per three $70 \mathrm{c}$ dozen $\$ 2.00$, per $25 \$ 3.00$.

Gold Bound. The finest white. Delicately lined with a clear gold.

Purple and Gold. One of the best growers Large purple flowers attractively spotted with gold.

Hercules. Large double. Delicate lavender.

ski-No-Ryo. A fine blue and white double.

Ioniji-no-taki. A bright rose marked with a deeper shade.

Cchiu. Large flowers of coerulean blue with white and gold centers. Long stems and erect growing. One of the best.

one of each named variety-6 plants $\$ 1.25$.

\section{SPECIMT OFFER}

A group of Jap Iris forms a striking mass of color. This offer includes a mixture of the named varieties which will give you some very choice plants 25 for $\$ 2.50$.

IRIS PUMILA. A dainty little bright purple Iris which blooms early in the spring. Grows only six inches tall and is fine for a border or in a rock garden. A worthwhile variety of high merit. Each $30 \mathrm{c}$, per three $80 \mathrm{c}$, per dozen $\$ 2.00$

LATHYREs. (Hardy Sweet Pea.) This is a fine cover plant. Trained over a fence or old stone wall this will literally cover itself with a profusion of bloom. Best in full sun. White Pearl, Pink Reauty, and Rosy Red. Each $20 \mathrm{c}$, per three $50 \mathrm{c}$, dozen $\$ 1.50$, per 25 $\$ 2.50$

\section{LAVENUULA}

Veris. The true Sweet Lavender. The dull blue-gray foliage, and the fragrant lavender flower make this a gem for the rockery. Blooms in June and July, and when cut and dried they retain their fragrance indefinitely. Each $25 \mathrm{c}$, per three $70 \mathrm{c}$, dozen $\$ 2.00$, per. $25 \$ 3.00$.

\section{LIATRIS}

Pychnostachia (Blazing Star). This fine norelty gives a brilliant touch of color to the back border. The long spikes of clear rose purple will stand out in any garden. Four feet high. Rapidly becoming very popular as a cut flower also. Each $25 \mathrm{c}$, per three $70 \mathrm{c}$ dozen $\$ 200$ per 25 .

Scarriosa (Kansas Gay Feather). Same color as above only the spike is not as dense. Gives a fluffy appearance and is attractive. It also blooms in July and Iugust. Same price as above.

\section{LILIES}

\section{HARIJY GARIDEY VARIETIES}

Candidums excepted, these should be planted, in partial shade and kept cool. They thrive best in leaf-mold, and it is advisable to place a little sand under and around each bulb.

Candidum must be planted in the Fall. Ali others are preferably Fall planted, but can be set out in the spring.

Lilium auration, and speciosum magnificum are imported from Japan. Many times we do not receive them until too late in the Fall to send them out. In this case we lold for early Spring delivery.

Regale. Probably the best white gardew lily ever introduced. Three to five feet blooms in July. Immense flower of Ivory White, tinted pink at base. Strong flowering bulbs. Each $40 \mathrm{c}$, per three $\$ 1.20$, dozen $\$ 4.00$, per $25 \$ 7.00$.

Canadensis. Red and yellow. The native yellow lily. 2 to 5 feet. Tery hardy. Each $20 \mathrm{c}$ per three $50 \mathrm{c}$, dozen $\$ 1.50$, per $25 \$ 2.50$.

Candidum (Madonna Lily). Large, fragrant, purest white. Each $30 \mathrm{c}$, per three $80 \mathrm{c}$, dozen $\$ 2.50$.

Elegans Umbellatum. Very large, upright deep apricot flowers: fine for the border. Each $25 \mathrm{c}$, per three $70 \mathrm{c}$, per dozen $\$ 2.00$, per $25 \$ 3.75$.

Tigrinum Splendens. The old familiar Tiger Lily. Each $20 \mathrm{c}$, per three 50 , dozen $\$ 1.50$, per $25 \$ 2.50$.

Tenuifolium. A dwarf coral red beauty froni Siberia. Perfectly hardy. This lily blooms before L. Regale. Its brilliant color and its attractive 'Turks' Cap shaped bloom makes it highly desirable. Recommended. Each $30 \mathrm{c}$, per three $80 \mathrm{c}$, per dozen $\$ 2.50$, per 25 $\$ 3.75$.

Superbum. A native, growing about 4 to $j$ ft. tall, dull orange. Fine for naturalizing. Each $20 \mathrm{c}$, per three $50 \mathrm{c}$, dozen $\$ 1.50$, per 25 $\$ 2.50$.

Auratum. (Gold Band Jap Lily.) One of the largest and finest Ivory white, thickly studded with brownish crimson spots, with a broad yellow band centering each petal. July to September, 3 to $5 \mathrm{ft}$. Each $40 \mathrm{c}$, per July to September, 3 to
three $\$ 1.10$, dozen $\$ 4.00$.

Speciosum Magnificum. A superb Japanese variety of an exauisite shade of red. Recommended. Each $50 \mathrm{c}$, per three $\$ 1.35$, dozen $\$ 4.75$.

\section{LILY OF THE VALLEY}

Strorig clumps for outside planting. Very useful ir shady corners, or at edge of shrubbery. Each $30 \mathrm{c}$, per three $80 \mathrm{c}$, dozen $\$ 2.50$, per $25 \$ 3.75$.

\section{LINCM (Perennial Flax).}

Perennae. A desirable plant for border or rock work. Light, graceful foliage; large blue flowers through July and Aigust. 1 inches. Each $20 \mathrm{c}$, per thrèe $50 \mathrm{c}$, dozen $\$ 1.50$ per $25: \$ 2.50$.

Perenna Album. Identical with above except pure white flowers. Price the same. 
I.0BI:L, (rardinal Flower).

Carlinalis. Intenso carlinal flowers arranged

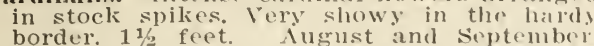

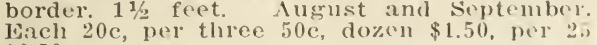
$\$ 2.50$

syphlitea. For a moist situation this bright blue flower is ideal. The spikies are similar to L. Cardinalis. Because of its beauty it is becoming mole populiu eich real bach $30 \mathrm{c}$, per three $80 \mathrm{c}$, lozen $\$ 2.50$, per 25 , $\$ 3.75$.

\section{I,UPINUS}

rolyplyylus. Spikes of pea like flowers in delicate, soft shades in May and Jume Shouid have rather heavy soil and a moist situation, or partial shade when out of bloom. Clear Blue, White, or Pale Rose, Eacli $25 \mathrm{c}$, per three $70 \mathrm{c}$, dozen $\$ 2.00$, per $25 \$ 3.00$.

\section{IYCHNIS}

Of very easy culture; will thrive anvwhere. This, together with their brightness, makes them general favorites in the hardy garden.

Chalceloniea. A most desirable plant: heads of brilliant scarlet. Isite June and July. 2 to 3 feet. Fach 20c, per three 50, per dozen $\$ 1.50$, per $25 \$ 2.50$.

Visearia splendens. In July and August sends up crimson flowers. The most rivid colored of any hardy perennial. Forms a dense tuft of evergreen foliage. Each 20c per three 50 c, dozen $\$ 1.50$, per $25 \$ 2.50$.

\section{I.THRUM}

Roseum. (Loose Strife). Tery showy plants, thriving in almost any situation. Isirge spikes of rose colored flowers from Julr t. September. Fine water-side subjects. Each 20 c, per three 50 c, dozen $\$ 1.50$, per $25 \$ 2.50$.

\section{LISAMACHIA}

Vummalaria, (Creeping Pennt) Bright grees foliage, with rellow flowers. Creeper. Fine glound cover for banks or under trens or shrubs. Each $20 \mathrm{c}$, per three 50 , per dozen $\$ 1.50$, per $25 \$ 2.50$.

MALI.OW MARVELS

Meehan's Mallow Marvels are s i m i la $\mathrm{r}$ in shape and growth to Hibiscus Crimson Eye The gigantic flowers, reaching a diameter of 8 to 10 inches, range in color from fiery crimson through various shades of pink to white.

Iixed Colors. Each $20 \mathrm{c}$, per three $50 \mathrm{c}$, dəzen $\$ 1.50$, per $25 \$ 2.50$.

Shades of Red and Crimson, Select. Lach $30 \mathrm{c}$ per three $80 \mathrm{c}$, dozen $\$ 2.50$.

Shades of Piuk, Select. Each $30 \mathrm{c}$, per thrce $80 \mathrm{c}$, dozen $\$ 2.50$.

\section{MERTENSIA (Bluebells).}

Virginica. An early spring-flowering native with drooping panicles of light blue flower: fading to clear pink. Well known to most of us who went wild-flowering in childhoor along the river-bottoms of the northern and middle states. May and June. 1 to $1 \frac{1 / 2}{2}$ feet. Each 20c, per three $50 \mathrm{c}$, dozen $\$ 1.50$ per $25 \$ 2.50$.

IONARDO (Bergamot).

Cambridge Scarlet. Showy plants with aromatic foliage, and producing brilliant crimson-scarlet flowers during July and August 2 to 3 feet. Each $20 \mathrm{c}$, per three $50 \mathrm{c}$, dozen $\$ 1.50$, per $25 \$ 2.50$.

Didyma Rosea. A handsome plant of the same type as Cambridge Scarlet. but the flowers are a bright rose. Each $20 \mathrm{c}$, per three $50 \mathrm{c}$ per dozen $\$ 1.50$, per $25 \$ 2.50$

\section{MYosotis}

Palustris semperflorens. (Forget-me-not) A pretty and useful plant in either the rock garden or the border. Should have half shade. The delicate blue flowers are charming. Each $20 \mathrm{c}$, per three $50 \mathrm{c}$, dozen $\$ 1.50$, per $25 \$ 2.50$

Palustris semperflorens rosea. The pink form of abore. A worthwhile addition for the rock garden. Same price as above.

NEPETA (Catmint)

Mussini. A low-branching plant bearing numerous lavender-colored flowers. Leave small, same color as sage. A most useful border plant. Each $25 \mathrm{c}$, per three $70 \mathrm{c}$, dozen $\$ 2.00$, per $25 \$ 3.00$.
Marerantha. A fince trailer for the rowkrev Covered during tho summer with dolicate lavender flowers. flual for tritiling ove rucks. Silver grey follage. Each 200, pe: threa 50c, ner (lozon $\$ 1.50$ por $25 \$ 2.50$.

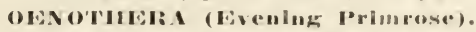

Missouriconsis. Thoer plants grow and flowe. cqually well in sum, or (lonse shate "Tlues aro covered with large golden yollow flow rers in Junc and July, 12 inchres tall, rathe. sproaling habit. Wich 25c, pror throf. 76. dozen $\$ 2.50$.

Youmgii. Taller and more compact than the above; flowers smallor but morr yorsistent longer blooming period liach 250 per. thre $70 \mathrm{c}$, dozen $\$ 2.50$, per $25 \$ 3.75$

\section{UIRNAMINIII, GIRASSIS}

Tery extensively used for beds and specimen clumps.

Eulalia Japonica Melorina. Gieen leaves crossed at intervals of 2 to 3 inches with broad bands of yellow. Wrch $20 \mathrm{c}$, per three 50 c, dozen $\$ 1.50$. per $25 \$ 2.50$.

Eulalia Gracilis Cnivituta (Japan Rush). Of graceful habit, very narrow foliage, briglit green with silver midrib. Perhaps the most used of the ornamental grasses, 4 to 5 feet. Each $20 \mathrm{c}$, per three $50 \mathrm{c}$, dozen $\$ 150$, per 25 $\$ 2.50$.

Eulalia Japonica Bariegata. Striped green and white. Each $20 \mathrm{c}$, per dozen $\$ 2.00$.

\section{PACHISANURA}

Terminalis. Broad mats of glossy greell leaves and small flowers in May and June. Indispensable as a cover plant in sun or shade. It is eminently suited for locations in dense shade, for it will make a luxurian growth where other plants would perish. The greenish white flowers are bune in spikes. Each 20c. per three $50 \mathrm{c}$, per dozen $\$ 1.50$, per $25 \$ 2.50$

\section{PAPAVER -ORIENTALE}

Orieutale Poppies. In the garden or in a border the poppy makes a gorgeous display of color in June. The large flowers are vivid, and you will find them very satisfactory. Our plants are all grown from cuttings, making them 100 per cent true to type. August is the best time to ship poppies, and we will book your order for Fall delivery.

Beauty of Livermore. Brilliant crimson with black spots. Fine. Each $35 \mathrm{c}$, per thrce $\$ 100$ dozen $\$ 3.25$

Bracteatum. Large orange scarlet with distinct dark spots in the center. Each $25 \mathrm{c}$, per th:ee $70 \mathrm{c}$, dozen $\$ 2.00$, per $25 \$ 300$

Irrs. Perry. A charming shade of pink. Large flowered. A very popular poppr and riohtfully so for it is a free bloomer and is a fine color. One of the best. Each 30c, per three $80 \mathrm{c}$, dozen $\$ 2.50$, per $25 \$ 3.75$

orientale. A bright orange scarlet. Free grower and splendid in a group. Each $20 \mathrm{c}$, per three $50 \mathrm{c}$, dozen $\$ 1.50$, per $25 \$ 250$

Perry's White. The most distinct break in poppies that has as yet been discovere 1 . It is clear white with a touch of crimson ir the throat. An excellent plant. Each 50c, per three $\$ 1.25$, per dozen $\$ 4.00$

One of wach named variety-5 plants $\$ 1.25$

PARDANTHUS (Blackberry Lily).

Chinensis. Flowers orange-color, spotted with purple-brown, and will arerage $2 \frac{1}{2}$ inches in diameter. The seeds which follow the blowm are quite like blackberries. 3 feet. Each $25 \mathrm{c}$, per three $70 \mathrm{c}$, dozen $\$ 2.00$.

\section{I'ENTSTINION}

(Bearl Tongue). A most useful and showy perennial. Some varieties are not har $1 y^{\prime}$ Those below are perfectly so. June and July. 3 feet.

Gorlonii Splendens. A June flowering border plant that has attracted much attention. Ten inch spike of blue overcast with rose a delightful combination. Recommended. Each $25 \mathrm{c}$, per three $70 \mathrm{c}$, per dozen $\$ 2.00$.

Torreyi. Spikes of bright scarlet flowers fromi June till August. A very effectire plant for hardy beds. Each 20c, per three 50c, dozen $\$ 1.50$, per $25 \$ 2.50$. 


\section{PENTSTEMON (Continued)}

Hybridum "Coral Gem." A sturdy grower with clear coral pink flowers. Louise Beebe Wilder, in the House and Garden, pays a nice tribute to this plant and P. Shell Pink - "Less well known are the two exquisite forms of barbatus introduced by Mr. Ralph Huntington. These are coral pink and shell pink, respectively, such lovely things!" We are grateful for this recognition of two fine perennials. Each $20 \mathrm{c}$, per three $50 \mathrm{c}$ dozen $\$ 1.50$, per $25 \$ 2.50$.

Hybridum, "Shell Pink" (Huntington). This first appeared with us in the same lot of seedlings with Coral Gem, but has not increased as fast. Spike is not as tall as Torreyii, and flowers are more plentiful on the spike. Color is a bright shell pink. Perfectly hardy in any soil or climate. "One particular sem is suggested for a garden that needs clear pink, a pink form of $P$. Barbatus. It is obtainable from Ralph $\mathbf{E}$ Huntington. Its color is all that can be clantington. Its color is all that can be scarlet of war, Torreyii, try this IaFrance rose-pink form." Stephen F. Hamblin, in the Garden Magazine. Field roots, 30c each. per three $75 \mathrm{c}$, per dozen $\$ 2.00$, per $25 \$ 3.00$.

\section{PEONIES}

Peonies, especially the modern introductions, are probably the most valuable of all perennial plants. Careful selection of flowers gives a wonderful range of color and extended blooming period. Once planted they require little care, but they will more than repay good culticare, but they will more than repay good culti-
vation in plentiful bloom, and of better quality.

PLANTING. Peonies may be planted in fall or spring, but fall is much to be preferred. Avoid planting deeper than 3 inches of soil over the crown or eyes. After planting, mulch well with stable manure to avoid winter "heavino." Remove this and spread about the plants when Remove this and spread about the plants when
freezing is over. Never cut flowers so that all the leaves are taken from the plant, and do not cut the stems below the first pair of leaves. This is a prolific cause of short lived plants.

RA'INGS AND OHIGIN. The figures given at left of each variety are the ratings given then by the American Peony society. In brackets is the name of the originator, and date of introduction.

All plants are three to five eyes. Peonies at dozen rate sent express collect. All orders are held for Fall delivery. Write for 25 to 100 lot quotations.

(8.7) Albatre (Crousse, 1885). One of the finest and easiest white peonies in cultivation. Immense globular flowers of milk white, shaded ivory, with tinges of lilac and carmine. Very strong and free, fragrant. Midseason. $50 \mathrm{c}$, dozen $\$ 5.00$.

(8.6) Albert Crousse (Crousse, 1893). Large, compact, bomb type, rose white (8) Fragrant, erect, free, late. $75 \mathrm{c}$, dozen $\$ 7.50$.

(8.1) Asa Gray (Crousse, 1886). Lilac, sprinkled with minute dots of deeper shading. A striking peony and perhaps the easiest grower in this list. In any soil or situation where peonies will bloom at all, Asa Gray will give fullest satisfaction in every way. It blooms well the first season, and
for every season thereafter. Early midfor every season thereaft
season. $50 \mathrm{c}$, dozen $\$ 5.00$.

( 8.1$)$ Couronne d'Or. Large, flat, loosely built flower of pure white with a ring of yellow stamens showing in center. Center petals tipped carmine. Medium height, very free grower and bloomer. Late. 50c, dozen $\$ 5.00$.

(8.6) Eugenic Verdier. Immense compact, rather flat flower of pale pink, center of deeper shade, flecked crimson. Erect and free, fragrant, mid-season. Extra good. $50 \mathrm{c}$ dc zen $\$ 5.00$
(9.3) Festive Maxima. Probably the most popular and best known of all peonies. Immense pure white flowers, with center petals lightly touched carmine. Always willing grower and free bloomer. Blooms with the earliest of the Chinensis sorts. $50 \mathrm{c}$, dozenl $\$ 5.00$.

(8.4) Felix Crousse (Crousse, 1881). A large brilliant red bomb on an erect, strong stem, rigorous and free, fragrant. Mid-season. One of the best red varieties. $60 \mathrm{c}$, dozen $\$ 6.00$.

(8.5) Germaiue Bigot (Dessert, 1902). Very large, medium flat flower, pale rose with lilac overlay, flecked crimson. Strong, erect, medium height, free. Mid-season. $75 \mathrm{c}$, dozen $\$ 7.50$.

(8.1) buchess deNemours (Calot 1856). Large and full. Nearly pure white. Free and fine. $40 \mathrm{c}$, dozen $\$ 4.00$.

(7.9) Gloire le Chas. Gombault (Gombault, $1866)$. Center of flower is light rose, with a collar of narrow cream petals, widening to. ward the center. Strong and free, generally serelal flowers on each head unless disbudded. Mid-season. $75 \mathrm{c}$, dozen $\$ 7.50$.

( 8.1 Marchioness of Lansdowne (Kelway 1899). Just why this variety has a lower rating than Therese we do not understand It is almost identical in form, size, growth, indeed, in every way, with the sole exception of color, which is a lively clear pink. With us it is ideal in every way, and personally we think more of it than any other pink that we have seen. It is very scarce and is seldom found in any wholesale list. Early mid-season. Each $\$ 3.50$.

(7.9) Mad. Ducel (Mechin, 1880). Medium size, bomb type, pale mauve rose, silver reflex. Fragrant, strong, and very free Extra market flower. Mid-season. $75 \mathrm{c}$, dozen $\$ 7.50$.

(7.6) Edulis Superba (Lemoine, 1824). Large loosely built, bright but soft pink, strong. upright and free. One of the oldest and still the most important Decoration Day Pink. $50 \mathrm{c}$, dozen $\$ 5.00$.

(8.7) James Kelway (Kelway). Very large rose white changing to milk white. Strong grower, early mid-season. $\$ 1.75$.

(8.8) KKarl Rosenfield (Rosenfield, 1908). Very large, compact, globular. Dark crimson. Tall and strong, ideal grower and very free. Mid-season. Extra fine red. $75 \mathrm{c}$, dozen $\$ 7.50$.

(8.4) King of England (Kelway). A grand single peony. Immense flat cup of rosy red with a large, soft yellow center. A quick grower, free and strong. In every way ideal. Grand sort for cutting, and an ideal subject for liandscape work at edge or ornamental border, woodland, or like situations, where it gives the effect of rhododendron but it gives the effect of rhododendron but Mid-summer. Each $\$ 3.00$.

(9.0) La France (Lemoine, 1901). Enormous rather flat flowers of soft apple blosson pink, with slight mauve reflex. Outer guard petals have a slight splash of crimson. Fragetals have a slight splash of crimson. Fragrance extra. Mid-season. An extra groo
grower and a wonderful flower. $\$ 4.00$.

(8.3) Lamartine (Calot, 1860). (Synonym Gigantea). Extra large, pale lilac rose, with darker center. Distinct fragrance, rather spicy. Tall and free. Mid-season. Extra grower. $75 \mathrm{c}$, dozen $\$ 7.50$.

(9.9) LeGygne (Lemoine, 1907). Perfectly formed, solidly built flower of creamy white, fading to milk white. The globular, compact bloom of this flower is distinct from all others, probably finest of all white peonies. Strong grower, free, in every way ideal. Late mid-season. Each $\$ 6.00$.

(7.3) L'Indespensable (o $\mathrm{r}$ i g i n unknown). Lilac White, shading to deep rose toward the center. A very double, handsome flower of immense size, free and extra good. $75 \mathrm{c}$, dezen $\$ 7.50$. 
l'izONIISS (Comtinued)

(7.9) Mad DeVerneville (Crousse, 1885). ()11. of the most charming and probably the best producer of flowers on the market. Medium size, well rounded flowers, white, shadinf up to a center of dclicate shell pink, extra fragrant. A fine landscape sort, ancl onc of the staple commercial cut flowers, birly mid-season. $50 \mathrm{c}$, dozen $\$ 5.00$.

(8.5) Mal. Euile Gaille (Crousse, 1881). ('ompact, rather flat flowers, deep lilac white shading to milk white center. Mcdium height, strong and free. A good late valliety. $50 \mathrm{c}$, dozen $\$ 5.00$.

(8.1) Mlle Leonie Calot (Calot, 1861). I sirge typical well rounded rose type. Very delicate rose white, shading to decper centcr. Tall, strong and free. Extra good, late nidTall, strong alld free. 50.

(8.5) Marie Lemoine (Calot, 1869). Large very solid, cream white, with pure white center. fragrant, medium height, stiff, heavy stem. Very lale. $50 \mathrm{c}$, dozen $\$ 5.00$.

(7.5) Mareehal Vaillant (Calot, 1864). Large, compact, globular flower of dark mauve pink. Tall, heavy, coarse stems, barely supdozen $\$ 5.00$.

(8.3) Mons Dupont (Calot, 1872). Large flat flower of nilk white, center lightly splashed crimson. Erect, tall, and free. A fine late mid-season white. $75 \mathrm{c}$, dozen $\$ 7.50$.

(7.8) Iodel de Perfection (Crousse, 1875). Wil named Light, violet rose, shading to center of flesh pink, silver tipped, strong and profuse bloomer. Late. $75 \mathrm{c}$, dozen $\$ 7.50$.

(9.2) Mons Jules Elie (Crousse, 1888). Very large flower, on stiff, strong stems, heavy glossy foliage. Pale lilac rose, with lightgraded amber yellow at base. This peony is the "Festiva Maxima" among the pink sorts. Early, extra good. $75 \mathrm{c}$, dozen 7.50 .

(8.8) Mons Martin Cahuzae. (Dessert, 1899) Massive, well rounded flowers. A solid ball of deep maroon with garnet shadings and black luster: Claimed to be the darkest good peony in existence. Good grower, erect and free. In great demand by those who want all shades and colors. Late mid-season. Each $\$ 2.50$.

8.5) Oetavie Demay (Calot, 1867). Very large flat tlowers, pale hydrangea pink, collar almost white. Very free, medium height. Fragrant. Late mid-season. $75 \mathrm{c}$, dozen $\$ 7.50$

(8.7) Reine Hortense (Synonym Pres. Taft.) Easily be rated higher. Large, heavy flowers, full double. A beautiful shade of soft pink with bright rose stripes on petals. A marvelous flower and a good grower. Very tall, strong, and heavy. Mid-season. $\$ 1.00$ dozen $\$ 10.00$

(7.2) Rubra Superba (Richardson, 1871) Flower of rich, deep, brilliant crimson, large full and double, and the best keeper of the whole peony family. Should be staked Late mid-season. $75 \mathrm{c}$, dozen $\$ 7.50$.

9.0) Sarah Bernhardt (Lemoine, 1906). Flower of remarkable size, unusual perfection of form, full and double. Apple blossom pink. fragrant, late mid-season. A grand peony. $\$ 1.00$, dozen $\$ 10.00$

9.7) Solange (Lemoine, 1907). Full globular flowers with a crested tuft in center Color rare and hard to describe. Center shows well defined shadings of tango orange or light brown, shading to pure white, with overlay of tender blush pink. $\$ 3.00$.

9.8) Therese (Desert, 1904). Immense, rather flat flower of violet rose, shading to light pink, the largest pèony in this shade. strong and free, early mid-season. $\$ 3.00$.

\section{PHLOX}

The hardy perennial phlox, because of the splendid selection of marvelous colors, is rapidly taking a leading position in the American garden. Its ability to succeed in most any position is another of its admirable qualities. For a mass of color try planting twenty-five of a variety. You will then see why we are offering all our plants this way. The real effect wilj please you. Strong field grown plants. Each $25 \mathrm{c}$, per three $70 \mathrm{c}$, dozen $\$ 2.00$, per $25 \$ 3.00$ unless otherwise noted.
Afrien. $\Lambda$ dazzling new deep searlet. $\Lambda$ vivid color and a strong grower. Whll not fude as som. reds do. A grem for the border.

beneou. Brillinnt cherry. Large flowers of line form.

18. Compre. Rich Burgundy-red, one of the tinest red shindes; strong and burge. 'True stock scarce.

(ommander. One of the most striking reds. In ज्ञात rstablished variety that stlll hold. its plice because of its fine color and form.

Gillel 'Iower. A strong-growing, large truss ed sort; thesh-pink with red eye. Wach 35 per three $\$ 1.00$, dozen $\$ 3.50$.

cirabeth campbell. The most popular of all Pink Plloxes. Purest salmon. Wach $30 \mathrm{c}$, pel three $80 c$, dozen $\$ 3.00$, per $25 \$ 5.00$.

linchintress. A new pink that is rapidly be coming popular. $\Lambda$ bright pink mottled with shading of white. A strong grower. Europa. Snow-white with decided carmine
eye. Very large individual flower and truss. Sturdy. erect habit.

Graf Zeppeliu (Count Zeppelin). A recent introduction of high merit. Large pure white flowers with a distinct crimson center. The best of its type. Each $30 \mathrm{c}$, per three $80 \mathrm{c}$, dozen $\$ 2.50$

Henri Menier. Mottled lavender and white Dwarf, with immense flower heads, reaching the ground on both sides of plant.

La Vague. Mauve colored with a distinct crimson eye. Strong grower and a profusion of bloons.

Liss Lingard. Waxy white, with lavender eye Longest spikes of any Phlox; blooms from the ground up. One of the first to bloon $A$ gond cut flower.

Prof. Virehow. Bright carmine with orange ovẻrlay.

Pantheon. The peerless pink. Extra-large. almost flat flowers of salmon-rose.

Rheinlander. Salmon-pink, deeper than E. Campbell; much larger; medium height.

Thor. Beautiful shade of blush pink. Free bloomer. An excellent phlox. Each 30c, per thiee $80 \mathrm{c}$, dozen $\$ 2.50$.

Vos Lassburg. This large pearl white phlox is especially attractive. Each head of bloom is large. A fine phlox.

Widar, New. Red-violet, large white eye. Fine head.

SIPECIAL OFFER of field grown Phlox. 25 strong plants, fine assortment of bright colors, our selection, for $\$ 2.50$. Sent by express.

PHLOX SUBULATA. A dainty creeping Phlox, which is simply covered with flowers in early spring; splendid for borders or ground covers. 4 inches.

Alba. A free-blooming pure white variety. Each $20 \mathrm{c}$, per three $50 \mathrm{c}$, dozen $\$ 1.50$, per $25 \$ 2.50$.

Lilaeina. Soft sky blue, or extremely light lilac. Each $25 \mathrm{c}$, per three $70 \mathrm{c}$, dozen $\$ 2.00$ per $25 \$ 3.00$

Rosea. Bright rose. Each $20 \mathrm{c}$, per three $50 \mathrm{c}$ dozen $\$ 1.50$, per $25 \$ 2.50$

vivid. Brilliant pink with a cardinal eve. One of the finest introductions. A gem for the rockery. Neat habit. Recommended. Each $30 \mathrm{c}$, per three $80 \mathrm{c}$, per dozen $\$ 250$, per 25 $\$ 4.00$.

PHLOX AMOENA. A low species about six inches high. Covered in the Spring with delicate pink flowers. Makes a fine border plant and is very showy in the rock garden. $25 \$ 2.50$.

PHLOX DIVARICATA CANADENSIS. (Wild Sweet William) Our native phlox, blooming in April and May. Large fragrant lavender b]ooms on slender wiry stems. A valuable plant in the wild garden or in the rockery. Each $20 \mathrm{c}$, per three $50 \mathrm{c}$, per dozen $\$ 1.50$, per $25 \$ 2.50$.

PHLOX GLABERfina. A low growing plolo with narrow evergreen foliage. The large pink flowers bloom in May. Fine to trail on a bank or in a sloping alpine garden. Each $20 \mathrm{~s}$, per three $50 \mathrm{c}$, per dozen $\$ 1.25$, per 25 $\$ 2.25$. 
PHLOX OVATA. (Carolina Mountain Phlox.) Iasses of attractive evergreen foliage with bright pink flowers in May. In great deoright pine for the low mand as an alpine plant. True stock. Each $30 \mathrm{c}$, per three $80 \mathrm{c}$, per dozen $\$ 2.50$

\section{PHYSALIS}

Franchetti (Jap Lanteru). Dense bushes, 2 feet, producing freely, interesting, lanternlike scarlet fruits in fall. The flower is insignificant. Each $20 \mathrm{c}$, per three $50 \mathrm{c}$, dozen $\$ 1.50$, per $25 \$ 2.50$

\section{PHYSOSTEGIA}

False Dramonhead. One of the most beautiful of our mid-summer flowering perennials, forming dense bushes bearing delicate tubular flowers. 3 and 4 feet.

Virginica. Bright clear pink. Each 20c, pel dozen $\$ 1.50$, per $25 \$ 2.50$.

vivid. A later blooming form of above, very free, and not quite as tall. Dense heads of rosy light purple. Each $25 \mathrm{c}$, per three $70 \mathrm{c}$, per dozen $\$ 2.00$, per $25 \$ 3.00$.

\section{PLATYCODON}

(Balloon Flower). Blooms constantly from July until late in September; flowers large, bell-shaped. Of extremely rapid growth, doing well in any soil. Perfectly hardy. 2 to 3 feet high.

Azurea. Blue. Each 20c, dozen $\$ 1.50$, per 25 $\$ 2.50$

Albun. Pure white flowers. Each 20c, per three $50 \mathrm{c}$, dozen $\$ 1.50$, per $25 \$ 2.50$.

\section{PLUMBAGO (Leadwort).}

Larpentae. Tiny red-edged leaves of apple green are a rich setting for spiky red buds and dense clusters of cobalt-blue flowers. A delightful border plant and exceedingly valuable on account of its late blooming valuable on account of its late blooming Each $25 \mathrm{c}$. per three $70 \mathrm{c}$, dozen $\$ 2.00$, per $25 \$ 3.00$.

\section{POLEYIONIUM (Jacob's Ladder).}

Coeruleum. Flowers bluish purple, small and t pronounced bell-shape. May and June. 2 feet. Each $20 \mathrm{c}$, per three $50 \mathrm{c}$, dozen $\$ 1.50$, per $25 \quad \$ 2.50$.

\section{PRIMUIaA}

Veris. The old "polyanthus" of grandmother"s garden. Still a very desirable item for the rockery or the border. The various shades of yellow, orange and crimson, make a bright showing in the early spring. Hach $20 \mathrm{c}$, per three $50 \mathrm{c}$, dozen $\$ 1.50$, per $25 \$ 2.50$.

Veris Innstead Giants. From the seeds of this splendid strain. Large flowers of shades f Each $25 \mathrm{c}$, per three $70 \mathrm{c}$, dozen $\$ 2.00$.

PIRE'THRUII (Painted Daisy).

Roseum. Early bloomer. Foliage finely cut and attractive flowers colored in all shades of rose, borne profusely on long, straight stems. A splendid cut-flower and conspicuous in the garden. Single and double. Each $25 \mathrm{c}$, per three $70 \mathrm{c}$, dozen $\$ 2.00$, per $25 \$ 3.00$.

cliginosun. Large white flowers, 3 inches or. more in diameter, from July to September. Each 25c, per dozen $\$ 2.00$

Extra Doubles, selected in bloom and grown from divisions. $100 \%$ double. Must be bloomed a second time before showing typical flower. Mixed in all shades, mostly pink and rose. Each $40 \mathrm{c}$, per three $\$ 1.00$, dozen $\$ 3.50$.

RANUNCULUS (Crowfoot).

Acris fl pl. Bright yellow blooms on stems 10 to 15 inches high. May and June. Each 20c, per three 50c, dozen $\$ 1.50$, per $25 \$ 2.50$.

\section{RUDBECKLA}

Purpurea (Purple Coneflower). Large drooping petals colored reddish purple, with a remarkably large cone-shaped center of brown, thickly set with golden tints in spiral lines. Excellent for bedding, and equally rod for grouping in masses of shrubbery. July to frost. 2 to 3 feet. Each $20 \mathrm{c}$, per three $50 \mathrm{c}$, dozen $\$ 1.50$, per $25 \$ 2.50$
Newmannil. Plentifully supplied with large single flowers of orange-yellow, with a prominent brown cone. Brilliant color effects may easily be produced with this variety. The blooms can always be depended us the plant is easily grown. $11 / 2$ to 2 feet. July to frost. Each $20 \mathrm{c}$, per three $50 \mathrm{c}$, dozen $\$ 1.50$, per $25 \$ 2.50$.

\section{SAPONARIA}

ocynoides. A very pretty dwarf creeper. Clouds of small bright pink flowers in July and August. Each 20c, per three $50 \mathrm{c}$, dozen? $\$ 1.50$, per $25 \$ 2.50$.

SALVIA (Meadow Sage).

Azurea Grandiflora. A Rocky Mountain native growing from 3 to 4 feet tall, producing during August and September, pretty blut flowers in greatest profusion. Each 20c, per three $50 \mathrm{c}$, dozen $\$ 1.50$, per $25 \$ 2.50$

Pitcherii. Similar to the proceding except the color is gentian-blue; the plant is not quite as tall and is later to flower. Each $25 \mathrm{c}$. per three $70 \mathrm{c}$, dozen $\$ 2.00$, per $25 \$ 3.00$.

\section{SAIFRAGA}

Delia. Grows about 1 foot high, forming masses of handsome, broad, deep green foliage which is very ornamental at all times. The pretty crimson-purple flowers which appear early in spring, make this doubly effective. Each $35 \mathrm{c}$, per dozen $\$ 3.50$.

orbicularis. Deep rose. Each 35c, per dozen $\$ 3.50$.

Splendeus. Rosy crimson. Each 35c, per dozen $\$ 3.50$.

\section{SCABIOSA}

Handsome plants in the border, persistent in bloom and fine for cutting. Easy to grow and very free.

Caucasica (Blue Bonnet.) A soft shade of clear lavender, with serrated petals. Each $25 \mathrm{c}$, per three $\$ 70 \mathrm{c}$, dozen $\$ 2.00$, per $25 \$ 3.00$.

Japonica. Smaller flowers than Caucasica plant taller, much more free, very persistent, long, clean stemmed flowers of light blue from July till fall. Fach 20 c, per three, $50 \mathrm{c}$, dozen $\$ 1.50$, per $25 \$ 2.50$.

\section{SEDUM}

These trailing alpines are highly recommended for the rock garden or for the border. They are hardy, and their neatness makes them ideal for the rockery. Each $20 \mathrm{c}$, pei three $50 \mathrm{c}$, per dozen $\$ 1.50$, per $25 \$ 2.50$.

Aere (Golden Moss). Tery dwarf; much used for covering. Foliage bright green, flower yellow.

Album. Native of northern Asia. Thick, linear leaves, flower white, with tiny red center. A fine dwarf for ground cover in either shade or sun.

Asiaticum. Native of India. Creeper with red flowers. Fine ground cover.

Lydium. A fine dwarf alpine which turns crimson in the fall. Neat habit. Excellent between rocks.

Glaucum. A handsome creeper which forms a carpet of blue green, turning to a deeper blue in the autumn. One of the most at tractive sedums.

Ibericum. A delightful species with large crimson flowers during the summer. The foliage which is dwarf and ver.y neat turn to a fiery red during the autumn making it a very useful rock plant.

Rupestre. Minature globes of brililant green This variety is excellent for use in rocks. A distinctive sort and a fine addition. Eacl $25 \mathrm{c}$, per three $70 \mathrm{c}$, per dozen $\$ 2.00$.

sieboldii. A charming alpine growing in min ature tufts. Glaucous foliage each leaf being rimmed with a circle of crimson. Tery attractive. Extra. Each $30 \mathrm{c}$, per three $80 \mathrm{c}$, dozen $\$ 2.50$

\section{SPECIAL SEDUM OFFER}

Three plants of eight varieties making fine addition to the rock garden. 24 sedum for $\$ 3.00$ by express. 


\section{EREC:I GIROWING SH:1)UMS}

spectabile. A beautiful, erect-growing specics with broad, thick light green foliage and immense heads of showy soft rose-colored flowers. Indispensable as a late fall bloom ing plant. Wach $20 \mathrm{c}$, per three 50 , dozen $\$ 1.50$, per $25 \$ 2.50$

spectabile Frilliant. Rich, dull red, identica! with Spectabile in all except color. Hatel $20 \mathrm{c}$, per three $50 \mathrm{c}$, dozcil $\$ 1.50$, per $25 \$ 2.50$

SI:MIPIRIVUM (Hen and Chickens.)

Tectorum. A very desirable alpinc to use in the rocks. Evergreen foliage tipped with red. Real dwarf. Very hardy and will grow on the side of a stone wall. Recommended. Each $20 \mathrm{c}$, per three $50 \mathrm{c}$, dozen $\$ 1.50$, per 25 $\$ 2.50$.

\section{SHAS'CA DAISY}

Anska. Large snowy white flowers in bloom continually throughout the fall. Splendid per $25 \$ 2.50$.

Areticum (Arctic Daisy). One of the best fall flowe ring perennials. Low rosette-like clumps of foliage of glossy dark green Blooms in veritable sheets of white in September and October on stems about $1 \mathrm{ft}$. Valuable in border or rockery. Each $25 \mathrm{c}$ per three $70 \mathrm{c}$, dozen $\$ 2.00$.

\section{SIDALCEA}

Rosy Queen. A very graceful perennial growing about three feet high with clusters of single pinli flowers. Fxcellent in the of single pinli flowers. Wxcellent in the A charming plant. Each $25 \mathrm{c}$, per three $70 \mathrm{c}$, per dozen $\$ 2.00$, per $25 \$ 3.00$.

\section{SPIREA}

Filipendula (Double-flowered Dropwort.) Pretty fern-like foliage; white plumy flowers on slender 18-inch stems. Fine for cuting and very ornamental when not in bloom. Each $25 \mathrm{c}$, ver three $70 \mathrm{c}$, dozen $\$ 2.00$, per 25 $\$ 3.00$.

Ulmaria fl. pl. (Meadow-Sweet). Double white flowers. June-July. $3 \mathrm{ft}$. Hardy and true grower. Each $25 \mathrm{c}$, per three $70 \mathrm{c}$, dozen $\$ 2.00$, per $25 \$ 3.00$.

\section{STACHYS (Woundwort).}

Lanata. A splendid edging plant for situations requiring strong foliage contrasts. The dense-growing plant is a sheen of silvery white,. the leaves having the substance and wooly gurface of felt. Small spikes of and wooly surface of felt. Small spikes of light purple flowers appear in July and per $25 \$ 2.50$.

\section{STATICE}

Latifolia. (Sea Lavender). A valuable and handsome plant with tufts of leathery leaves. Immense heads of light blue, minute flowers, fine for cutting, ard if cut and dried last in perfect condition for months. July and August. $1 \frac{1 / 2}{2}$ feet. Each $25 \mathrm{c}$, per three $70 \mathrm{c}$, dozen $\$ 2.00$, per $25 \$ 3.00$.

\section{S'TOKESIA (Stoke's Aster)}

Cranea. One of the most charming hardy plants, blooming freely from July to October. Flowers of centaurea-shape, often measuring 4 to 5 inches across, making a rich

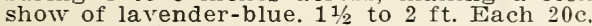
per three $50 \mathrm{c}$, dozen $\$ 1.50$, per $25 \$ 2.50$.

Cyanca Aba. Similar to above, but purest white, free blooming. Each $20 \mathrm{c}$, per three $50 \mathrm{c}$, dozen $\$ 1.75$, per $25 \$ 2.50$.

\section{TEUCRIUM}

Canadensis. Dwarf, evergreen tufts of varnished green with short spikes of lavender
rose flowers. A plant of high merit for the rose flowers. A plant of high merit for the
rockery. Very neat in habit and a strong grower. Each 25e, per three $70 \mathrm{c}$, per dozen
$\$ 2.00$.

\section{THALICTRUM}

Dipterocarpum. One of the most popular perennials in the entire list. Graceful and delicate lavender flowers tinged yellow cover erect three foot stems. The foliage is also highly decorative. A splendid border plant of high merit. Recommended. Each $30 \mathrm{c}$, per three $80 \mathrm{c}$, per dozen $\$ 2.75$, per $25 \$ 4.50$.
Adiandifobum. 'This splentlel valetety has fermlike foliage making it e.specelally attractive The tlower which is hiown and yellow blooms in early. June. 'The folluge keress it charming appearance all summer. Giarl $30 \mathrm{c}$ per three $80 \mathrm{c}$, do\%en $\$ 2.50$

cquickiafolium Purpureum. (Jeatlery colum bline). 'Tall peathery spikes of derep lavende flowers. Very attractive ill the borles Forms a bright spot in the border from May until July. Wach $25 \mathrm{c}$, per three $70 \mathrm{c}$, per dozen $\$ 2.00$

\section{IIINUS}

Serolnyium Coceinens. $A$ very pretty dware alpine which forms clouds of minature rose tinted flowers in early June. Highly recom mended for the rockery or the low border. Neat in habit. Fach $25 \mathrm{c}$, per three $70 \mathrm{c}$ dozen $\$ 2.00$, per $25 \$ 3.00$.

Ianuginosa (Wooly Thyme), A neat, prett alpine with grey grcen foliage. The flower is a dainty pink. Excellent in the rocks Dwarf growing and desirable in the low border. Each 25c, per three $70 \mathrm{c}$, per dozen $\$ 2.00$

\section{IIARELLA}

Cordifolia (Foam Flower). A charming littl native, about four inches tall, with short foamy white spikes in early spring. Good ground cover for shady situations. Each $20 \mathrm{c}$ per three $50 \mathrm{c}$, dozen $\$ 1.50$, per $25 \$ 2.50$.

\section{TRILLIUN}

Grandiflora (Wake Robin). Fine native fo shady places in the border or in low, wet situation. Large white or pale pink flowers in early spring. Each $20 \mathrm{c}$, per three $50 \mathrm{c}$ dozen $\$ 1.50$, per \&5 $\$ 2.50$.

Erectum. Same habit and price as above but the flowers are a rich maroon. Tery pretty and unusual.

\section{TRITOMA (Red-Hot Poker).}

Pfitzerii. An improved type of most perfect form, and showing a marked predominance of scarlet, the opened flower petals merely being rimmed with orange. Each $25 \mathrm{c}$, pe three $70 \mathrm{c}$, dozen $\$ 2.50$.

Express. Earliest of all Tritomas; very use ful in the hardy border. Comes into bloom six weeks before Pfitzerii. For continuation of bloom use both sorts. Each $15 \mathrm{c}$, per three $40 \mathrm{c}$, dozen $\$ 1.25$, per $25 \$ 2.00$.

\section{'TR OLLI US}

Europeus. (Orange Globe Flower.) Giant yellow buttercup-like blooms. Glossy dark green foliage. Does well in partial shade. Each $35 \mathrm{c}$, per three $80 \mathrm{c}$, dozen $\$ 2.50$.

Ledebourii. One of the best of all Trollius. The large deep orange flowers are set on long graceful stems. This is the latest to bloom and lasts longer than any other. A worthwhile variety. Each $50 \mathrm{c}$, per three $\$ 1.00$, per dozen 3.00 .

\section{IUNICA}

Saxifraga. Very dwarf, with grasslike foliage and covered with tiny pink flowers throughout the season. A fine, orderly border plant. Each $20 \mathrm{c}$, per three $50 \mathrm{c}$, dozen $\$ 1.50$, per 25 $\$ 2.50$.

VALERIANA (Garden Heliotrope)

Coccinea. Shows heads of flowers in shades of old rose. 3 to 4 feet Each $20 \mathrm{c}$, per three $5 \mathrm{cc}$, dozen $\$ 1.50$, per $25 \$ 2.50$.

Officialis. The finest valerian. Delightfully fragrant. Large heads of white on stiffl upright stems $2 \frac{1 / 2}{2}$ to $3 \mathrm{ft}$. tall. Stately and beautiful. Fine for cutting. July. Each $25 \mathrm{c}$, per three $70 \mathrm{c}$, dozen $\$ 2.00$, per $25 \$ 3.00$.

\section{VERONICA}

This group of perennials has long had an important part in adding color to the border and rock garden. They are hardy and will give a succession of pleasing bloom.

Amethystina. Amethyst-blue flowers in July and August. 2 feet. Each $20 \mathrm{c}$, per three $50 \mathrm{c}$, dozen $\$ 1.50$, per $25 \$ 2.50$.

Elegans Rosea. A neat dwarf for the rock garden. Slender spikes of pink rise nine inches above the tufted foliage. June-July blooming. Each $20 \mathrm{c}$, per three $50 \mathrm{c}$, per dozen $\$ 1.50$, per $25 \$ 2.50$. 
Incana. Bright silvery foliage with slender spikes of amethyst-blue flowers in July and August. For borders where lighter-colored foliage is wanted, this has no equal, giving all the effect of the geranium. Mme. Salleroi (Silver Leaf), with all the advantages of being hardy and fit for use year aftel year. 1 foot. Each $20 \mathrm{c}$, per three $50 \mathrm{c}$, dozen $\$ 1.50$, per $25 \$ 2.50$

Longifolia Subsessilis. One of the aristocrats of the Veronica family. Heavy spikes of an intense blue cover the plant through July and August. Makes a brilliant spot in the border. About two feet tall. Recommended. Each $30 \mathrm{c}$, per three $80 \mathrm{c}$, per dozen $\$ 2.50$, per $25 \$ 3.75$.

Prostrata. Light blue flowers, very low growing, soud rock plant. Each $25 \mathrm{c}$, per three $70 \mathrm{c}$, per dozen $\$ 2.00$.

Repens. This variety is very dwarf, forming ing a miniature carpét of dark green. It has delicate blue flowers which bloom in May. Should be planted on light well drained soil. Excellent for the rockery. Each $25 \mathrm{c}$, per three $70 \mathrm{c}$, dozen $\$ 2.00$, per $25 \$ 3.00$.

Rupestris. A fine plant for rockery or low border. Closely matted deep green foliage completely hidden in May and June with clouds of bright blue flowers. Each $25 \mathrm{c}$, per three $70 \mathrm{c}$, dozen $\$ 2.00$, per $25 \$ 3.00$

True Blue. A Lissadell origination Similar in growth to $\mathrm{V}$. Amethystina, but remains stiffly upright when in bloom. Stem is about 16-18 inches with flower spike of is about $16-18$ inches with flower spike of
vivid, deep blue. Each $25 \mathrm{c}$, per three $70 \mathrm{c}$, dozen $\$ 2.00$, per $25 \$ 3.00$.

VINCA (Myrtle)

Iinor. Fine evergreen creeper. Largely used for ground-cover in shady places where grass will not grow. Much used for covering graves. single light blue flowers in June and July. Strong field roots. Each $20 \mathrm{c}$, per three $50 \mathrm{c}$, dozen $\$ 1.50$, per $25 \$ 2.50$.

\section{IOL.A}

coruuta. The perennial Everblooming Pansy. Smaller than the pansy, but are constantly in full bloom from earliest spring till hard frosts. Invaluable in the hardy border and colorful in the rock garden.
Admiration. Large clear purple. Profusion of bloom.

Blue Perfection. A light blue slightly veined gold in the center.

Lutea Splendens. A bright showy yellow. One of the best.

Papilio. China blue mottled white. Attractive

White Perfection. Plant covered with large snow white blooms.

Each 20c, per three 50, per dozen $\$ 1.50$, per $25 \$ 2.50$

SPECIAL OFFER-Three of each variety-15 plants for $\$ 2.00$.

Cornuta, G. Wermio. Small dark violet flowers on long stems, a vertiable sheet of bluom the whole season. Those who admire Violet Princess of Wales will appreciate this easily grown substitute. Fine for cutting. Each $20 \mathrm{c}$, per three $50 \mathrm{c}$, dozen $\$ 1.50$, per $25 \$ 2.50$.

Jersey Geum. One of the best of the newer introductions. This fine rock garden item is becoming increasingly popular because of its unequaled merit in the rockery, or border. It shows a continual bloom of vivid purple from early summer until frost. Highly recommended. Each $25 \mathrm{c}$, per three $50 \mathrm{c}$ per dozen $\$ 1.50$, per $25 \$ 2.50$.

Scotch Border Mrixed. This fine variety grown from seeds of selected plants. It is a remarkable mixture containing extra large flowers in colors ranging from white through purple, crimson, yellow, mauve, blue and lavender. Recommended. Each $25 \mathrm{c}$ per three $70 \mathrm{c}$, per dozen $\$ 2.00$, per $25 \$ 3.00$.

\section{TIOLET'S}

Harly Russian or English. Perfectly hardy sweet-scented; deep purple. The only rea hardy sweet violet. Each $20 \mathrm{c}$, per three $50 \mathrm{c}$, dozen $\$ 2.00$, per $25 \$ 3.00$.

UCCA

Filanentosa (Adam's Needle; Spanish Bayoret). A stately foliage and flowering plant. The broad, sword-like foliage is evergreen mid-summer shows erect branching stem. bearing a showy display of pendant, creamy white bells. Each 20c, per dozen $\$ 2.00$. Strong 3-year plants, by express, each $30 \mathrm{c}$ dozen $\$ 3.00$.

\section{HARDY SHRUBS AND VINES}

LIST of a few shrubs and vines that have been exceptionally popular. We A have materially cut down the list of shrubs for we want to devote all our time to the raising of alpine, and perennial plants and seeds-but these shrubs are indespensible, and are really worthwhile and satisfactory.

We grow all these varieties and they are large sized plants with strong, well established root systems. They wiil flower and grow successfully for you, and we have reduced the price on these to renew the interest of our clients in these outstanding varieties.

CLEMATIS Paniculata.

Flowers medium sized, sweet scented. The whole plant is a sheet of white in september. Strong two year old plants-40c each, per dozen $\$ 3.50$.

CLETHERA Alnifolia.

(Sweet Pepper Bush) A handsome well rounded little shrub. Showy creamy white flowers in August. 18 to 24 inches. Each 40 c, per dozen $\$ 3.50$.

EUOTYYous Radicans Vegetus.

A fine evergreen creeper. Unsurpassed as a low wall cover or for heavy border. Glossy bright foliage and orange red berries through out the winter. Each $30 \mathrm{c}$, per three $80 \mathrm{c}$, per dozen $\$ 2.50$

HONEYSUCKLE Hall's Japan.

White and yellow extremely fragrant. Almost evergreen dark green leaves. A fine honeysuckle. Each $35 \mathrm{c}$, per three $90 \mathrm{c}$, per dozen suckle. $\$ 3.00$.

\section{PHILADELPHUS Virginale.}

(Mock Orange). The largest flowered really hardy Philadelphus. A very free and fragrant bloomer with large wax-like white flowers. Strong plants. Each $30 \mathrm{c}$, per three $80 \mathrm{c}$, per dozen $\$ 2.25$.

\section{POLYGONUM Ambertii.}

(Silver Lace Vine). A fine sturdy climber. A quick grower and a beautiful sight with its foamy white flowers in late summer. Recom mended. Each $30 \mathrm{c}$, per three $80 \mathrm{c}$, per dozen $\$ 2.50$.

SPIREA NORMANII

An extra dwarf form of spirea A. Waterer. Introduced by the wholesale grower, Mr. T. R. Norman of Painesville. An ideal border shrub and very useful for low massing. Turns a fiery brilliant scarlet in the Fall. Perfectly hardy. Each $60 \mathrm{c}$, per three $\$ 1.50$, per dozen $\$ 5.00$.

VIBURNUM Carlesii.

This is one of the finest shrubs in cultivation. Blooms are like a minature Kalmia. Fragrance equal to the Daphne or the Trailing Arbutus. Attractive foliage with a slight silver tint. Must be balled and burlapped and prices given are for plants sent via express. 18 to 24 inches. Stout plants-Each $\$ 2.00$, per three $\$ 5.00$

DAPHNE Cneorum and AZALFA Mollis. are listed with the Perennial Plants. 


\section{ROSES}

$\mathrm{O}^{-12}$

UR ROSE List is necessarily short for we have decided to catalogue only those varieties which have proven themselves perfectly satisfactory, meriting a place in any collection of roses. Every rose in the list stands out as one of the finest in its class.

All the roses are strong, hardy plants with superior root systems which will assure you of their doing well in your garden the first year. We would recommend that you plant roses early in the Spring. We will send all roses ready to plant, and guarantee them to arrive in first class shape.

A garden of roses chosen from the following list will prove a continual delight all through the summer.

\section{HYBRID TEA ROSES}

BE'I'I' UPIRI'HARI). A charming rose shaded deep carmine overcast with an orange bronze tone. Has a delicate shrimp pink center.

DA.E EDITH HELEN. A magnificent rose of a glorious shade of vivid pink. Heary well curled petals. Delightfully fragrant.

E. 'T. THOM. A brilliant clear rich yellow. One of the best of its color. A free bloomer and fragrant.

GRUSS AN 'TEPLITZ. A fine rich scarlet shading to a deep crimson. One of the most satisfactory in the entire list. Blooms most profusely, and will succeed under the most trying conditions. Its fragrance is delightful.

LOS ANGELES. One of the finest roses ever introduced. Rich flame-pink beautifully shaded with coral. An exquisite rose. A strong grower and delightfully fragrant.

MADAME BUT'TERLY. This rose is perfectly b]ended in color, white, bright pink, apricot, and gold forming the harmonious shades. A fine, recommended rose.

MADAME CAIBOLINE TESTOUT, One of the finest in its color class. Crimson shaded silver, deepening at the center to a bright cherry red.

SENSATION. One of the best bright crimsons Heary petals of clear crimson. A strong grower and always satisfactory.

SOUV. DE CLAUDIUS PERNET. The most satisfactory yellow rose. Bright clear vellow witl a deeper tone at the center. A strong, hardy rose. Recommended.

WILLIAY F. DREER. A beautiful rose colored silvery shell pink perfectly suffused with a rich golden tint. One of the best.

EDEL. Purest white except at the base of the petals where they are ivory shaded. Extra large blooms which are very satisfactory. A continuous and sure bloomer. Recommended.

RED RADIAXCE. This brilliant scarlet is always in bloom. This rose is sure to give satisfaction.

RADIAYCE. A beautiful blending of rose, opal, and copper. This rose and Red Radiance have been voted the most popular by the American Rose Society.

WILHELM KORIES. One of the newer roses. A golden orange fiushed delicately with copper-red. A healthy, strong growing rose. The foliage is also very attractive being a gleaming mass of red.

MME. ALEXANDER DREUX. An excellent rose shaded tangerine. Shapely flowers on strong, erect stems. One of the finest in its color class.

PRICES of Hybrid Tea Roses. Each 90c, per three \$2.40, per ten \$7.00.

\section{HYBRID PERPE'TUAL ROSES}

The excellence of the following list of these strong growers is strengthened by the fact that a list of really fine roses is not complete without them. In form, fragrance, color, and hardiness they are unsurpassed.

FIRA KARL DRCSCIKI The ideal hardy white rose. Large flowers of perfect form which bloom most profusely.

GENERAL JACQUEMINO'T. Commonly and affectionately called "General Jack." The most reliable, free blooming rich crimson.

GEORGE ARENDS. The "Pink Druschki". A delicate rose of exquisite texture. Highly fragrant. Superb in every way.

MIE. ALBER'T BATBIER. A magnificent new variety. Pearl white suffused with bright pink, the lower petals being a golden apricot. Recommended.

HRS. JOHN LAING. A highly fragrant soft pink. A continuous bloomer which always does well. Rated highly.

PACL NEYRON. Perhaps the largest rose of its type. A bright glowing pink shaded deeper. The stems are almost thornless. One of the best.

PRICE of Hybria lerpetual Roses, Each ste. per three $\$ 2.00$, per 10 , $\$ 6.50$.

\section{HARDY CLIMBING AND RAMBLER ROSES}

For covering a trellis, an arbor, or running up a porch these roses are indespensible. The will bloom profusely, adding a delightful touch of color to the garden. All these varieties are recommended.

A IA'TECIR BLERIO'T. Exquisite buds of bright yellow tinted apricot which open to clear light yellow. Sweetly fragrant. Recommended.

CLIVBIXG AVERICAN BEAETY. One of the most popular. A beautiful rose pink color. Free bloomer.

DOROTHY PERKINs. Large clusters of shell pink flowers. Tery fragrant. A fine rose.

DR. TAN FLEET. Delicately shaded blush pink. A rose of fine substance and especially good for cutting.

FLOWER OF FAIRF'IELD, A continuous crimson bloomer. The rich crimson color is very attractive. Recommended.

PALL'S SCARLET CLIMBER. A rivid scarlet. One of the most brilliant roses. Clusters of freely blooming semi-double flowers. One of the really popular climbing roses.

WHITE DORO'THY PERKINS. Without doubt the best white climber. Identical with Dorothy Perkins except in color. Its clear white flowers are very dainty.

PRICES of Climbing Roses. Each $75 \mathrm{c}$, per three $\$ 2.00$, per $10 \$ 6.00$. 


\section{GLADIOLUS}

$\mathrm{T}$ 'HE Gladiolus gives more beauty, color', and stately grace than any other' flower in the entire list. The marvelous blendings of different hues add a touch of brightness to a garden that makes the Gladiolus indespensible.

Gladiolus can always be depended upon to bloom profusely, they are inexpensive, and as a cut flower they are unequalled.

The following varieties represent the best of the established kinds. Each variety has a distinction that makes it standout.

These large, clean, true-to-name bulbs will add materially to your garden and will give you a succession of attractive bloom all season.

\section{FINE NOVELTIES OF RECENT INTRODUCTION}

( APTAIN BOYNTON. Large lavender flowers well placed on long stems. One of the finest of its color. $\ldots \ldots \ldots \ldots \ldots \ldots \ldots \ldots \ldots \ldots$

CARDINAL PIRINCE. A beautiful
self colored flower of brilliant vermillion. A splendid cut flow-

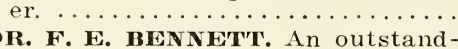

IR. F. E. BENNET'. An outstand-
ing peach red overcast with flame scarlet. Excellent. .......

FEIRN KYLE. A large ruffled cream. Flower's of excellent texture.

GLORIANA. A beautiful golden salmon with a clear yellow salmon with a clear yellow
throat. Tall spikes with many throat. Tall spikes with many

GOLDEN DREAM. A clear deep

golden yellow of fine substance. .40 $150 \quad 2.50$

GOLD EAGLE. A very early fine light yellow. A worthy introduction.

MRS. LEON DOUGLAS. Perhaps one of the largest glads in existence. A beautiful begonia rose mottled with red. Asingle bloom makes a bouquet in itself.

ORANGE FLAME. Large blooms of bright orange. Strong upright grower.

$60 \quad 2.00 \quad 3.00$

$\begin{array}{llll}50 & 1.50 & 2.50\end{array}$

$50 \quad 1.25 \quad 2.00$

$60 \quad 2.00 \quad 3.00$

$60 \quad 2.00 \quad 3.00$

I. W. SIssoN. The outstanding pink. A delicate pink yet with a dazzling undertone of rose Vivid but pleasing. Lasts well as a cut flower. .....................

- TRPLE GLORY. An older variety but still has all the virtues
to be listed with the best. The one real purple maroon.

W. H. PHIPPS. Delightful LaFrance pink overcast with salmon rose. One of Mr. Diener's mon rose. One of Mr. Diener's
finest originations. . .............40

SPECIAL OFFIIR. One each of these twelve fine novelties, \$1.75-Three each of the twelve, 36 bulbs. $\$ 3.50$.

\section{LARGE FLOWERED HYBRIDS}

ANN EBERIUS. A fine deep purple with blooms well placed on

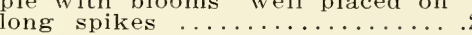

AN'THONY B. ISUNDERD. A large tall, intensely ruffled flower of cream overlaid with delicate pink. A fine variety.

ALBANIA. A very vigorous white of fine texture. The flowers are large and many are open at the same time

BARON J. HULO'T. A deep indigo purple. A most unusual color Excellent in a bouquet. Medium sized flowers. ........................ $1.00 \quad 1.75$ per per per

HYRON L. SMI'H. A lavender pink on a white ground. Much like a fine orchid. A very effective cut

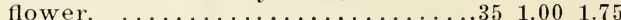

CRIMSON GLOW. An early crimson One of the finest in this color. Many flower's open at the same

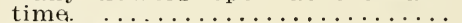

E. J. SHAYLOR. A tall ruffled

deep rose. …................ ered by many as one of the best. Rosy pink bordered with deep rose. A graceful variety. ........

GLIZABE'YH 'TABOR. Delicate rosy pink on white ground. Lower
petals have a rich crimson blotch petals have a rich crimson blotch pure yellow. An extra early bloomer. A fine cut flower variety. $\quad \ldots \ldots \ldots \ldots \ldots \ldots \ldots \ldots$

GOLDEN MEASURE. A magnificent golden yellow. The glad by which all others are judged. Large full spikes of graceful beauty. Recommended. ...........

JOE COLEMAN. A large spike of cherry red. A handsome ruffled variety of high merit. Very

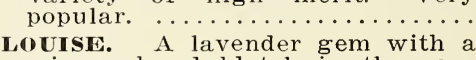
wine colored blotch in the center. The spilie carries large well opened blooms of a distinctive quality $\ldots \ldots \ldots \ldots \ldots \ldots \ldots \ldots$

LOS ANGELES. Lovely shrimp pink with attractive throat marking of glowing orange-calmine. ....

IIRS. DR. NORTON. Finest cream on pink. A lovely glad. ........ MIS. FRANK PENDLETON. Bright
rose pink on pure white ground. Large vermillion spots on lower

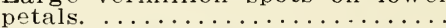

MRS. FIRANCIS IKING. A very effective flame scarlet. A fine variety. Exceptionally good as a cut

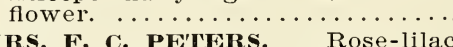

IRS. F. C. PE'FERS. Rose-lilac
with crimson blotch neatly borwith crimson blotch neatly bor-
dered in white. A strong grower.

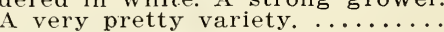

RICHARD DIENER. Large bright pink flaked with delicate pink

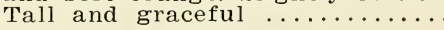

ROSE ASH. A vigorous grower. A bright rose color overcast with

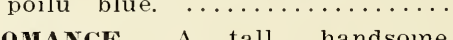

OMANCE. A tall handsome, spike of mauve rose edged steel
blue. No other glad has quite the blue. No other glad has quite the
coloring of this magnificent vaiety $\ldots \ldots \ldots \ldots \ldots \ldots \ldots \ldots \ldots \ldots \ldots .40 \quad 1.25 \quad 2.25$

RUTH HUNTING'TON. A beautiful ruffled glad. Large, full
bloomed spikes of striking violet-lilac. Most satisfactory. $\quad \ldots \ldots .40 \quad 1.25 \quad 2.25$ 
(iL.AbIOLI'S (Continued)

SCAILANO. A fine spikc of briglit orange red. Tall growing. The unusual color is very attractive unusual color is very attiactive. An early bloomer.

SWEI' IAVNISIR. This lovely lavender glad, blotched with a clear purple, is one of the earliest. A fine cut flower variety .25 .85 1.50

YOLE' BEIIVY. A ruffled cerise overlaid with violet. Red blotches in the throat. An excellent cut flower, as it comes into bloom real early.

SPECIAL OFFER. One each of any twelve, your selection, 12 bulbs \$1.25. One each of the named varieties, 24 bulbs $\$ 2.00$.

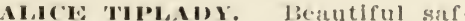
fron orange Still one of the bust. GOH.JWN SWALLOW. $\Lambda$ graceful and unique gold tinted glad. Recommended. MAIIIN'S HI, A pale pink of excellent quality. $.20 \quad .60 \quad 1.00$ IIR. $\Lambda$ fine deep orange over yellow ground.

ORANGis GUEIs. A delightful orange, finely overlaid witl bright apricot.

SOUVENIR. A bright clcar ycllow. well placed on graceful stems, $20 \quad .60 \quad 1.00$ SPECIAL, OFHER. One each of six varieties, 50c. Three each of six varieties-18 bulbs $\$ 1.25$.

\section{HERBS}

A collection of medicinal and sweet herbs that are very interesting. We would recommend that you devote a small section of your garden to these varieties which will give you an odd and entertaining as sortment.

ARTEMESIA Absinthium. See perennial seed list.

ARTFMESIA Dracunculus. (Russian Tarragon) $\ldots \ldots \ldots \ldots \ldots .10 .25$

ASPERULA Odorata. See perennial seed list.

ANETHUM Graveolens. (Dill) ... . .05 .15

BALSAMITA Vulgaris. See Perennial seed list

CARUM Carvi. (Caraway Seed) . . .05 .15 CARTHAMUS Tinctorius. (Saf-

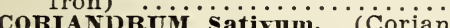
RIANDRUM Sativum. (Corian-

der)
FENNEL Comimon $\ldots \ldots \ldots \ldots \ldots \ldots \ldots \ldots . .05$

HYSsopus officinalis. See perennial seed list.

LAVENDULA Spica. See perennial seed list.

MIMULUS Moschatus. See perennial seed list.

MENTHA Crispa. (Curled Mint) … .15 .35

MENTHA Piperita. (Pepeprmint) .15 i.35

NEPE'TA Cataria. (Catnip) .... 10.20

ROSMARINUS Officinalis. See perennial Seed List.

SALVIA Officinalis. (Common

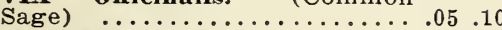

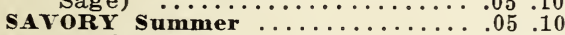

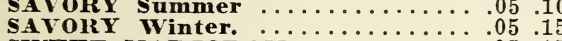

SWEET MARJORAM. … …

THYME Winter. Broad leaved. . . .05.15

THYMUS Vulgaris. See Perennial Seed List.

\section{SPECIAL CHRISTMAS OFFER}

Our special Christmas offer of Seeds has met with wide appeal for several years. Heretofore we have limited it to annual seeds. This year it includes all of our seeds.

We are offering a twenty percent reduction of seeds, both perennial and annual, purchased in December for Christmas. Because we cannot be certain that all our seeds will be in stock by that time we must request that a second choice list be sent along with the order so that we can fill it completely. If this second choice list is not included we will substitute with varieties of equal or greater worth than the seeds ordered.

Seeds make a fine gift to the Garden Lover. The $20 \%$ reduction makes the offer especially attractive.

\section{Collections of Plants}

We have listed these fine values through out our perennial and alpine plant section. An economical and satisfactory way to get a fine garden.

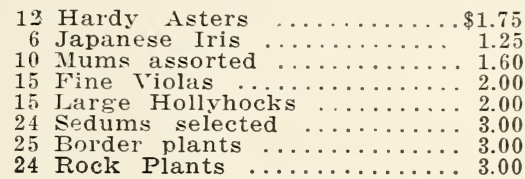

131 Splendid large plants for only $\$ 14.00$ ( $\$ 17.60$ value) Via Express collect.

\section{INSTRUCTIONS REGARDING EXPRESS SHIPMENTS}

All plants listed by the 25 are sent via Express collect. This assures you that the plants will be extra large sized, packed carefully, and will reach you in excellent condition.

It is important that you give definite shipping instructions-name of express office, your name and address. If you have no Express office in your city, kindly give the name of the office to which the shipment is to be made.

If you would rather have the plants sent via parcel post, especially if you have an R. F. D. address, we will be pleased to send them that way, packed as lightly as possible. Kindly add $5 \%$ to the total of order to cover postage. Add 10\% for post offices west of the Mississippi River.

Remember this applies only to large orders in 25 plant lots-but if you desire extra large plants in smaller lots we will also send them according to the above instructions.

We strongly recommend the Express shipment for it permits us to give you the largest plants we have, and these strong plants prove very satisfactory. Because we have received many sincere compliments from our clients y sincere taken advantage of receiving extra large plants by Express we feel that this method of shipment is to be recommended.

"Received the wonderfully fine plants in perfect shape"- "Express shipment received, large plants were packed carefully and are in good condition". This is the way our customers feel in regard to our plants. We know that you will be delighted with them-and when you compare prices you will be further impressed with the real value of our plants. 


\section{How To Get Best Results With}

\section{Huntington's Seeds}

$\mathrm{P}$ ERENNIAL seeds are not as difficult to handle as many people imagine. With ordinary care there is not an item which we list that cannot be successfully grown. We will admit there are a few that require extra attention but success with these amply repays for every bit of extra work. Growing plants from seeds is a fascinating hobby, and in our list of seeds you will find many that are very easy, yet the plants are rare in this country, and the most ecomonical way you can get them is by growing them from seed.

The following instructions are necessarily brief but they cover the important requirements in the sowing of perennial seeds.

A large majority of the seeds should be sown in the Spring. Each April we start to sow our seeds, getting in such items as Hollyhocks, Gaillardia, Coreopsis, Delphinium (Belladonna, Bellamosa, and English Hybrids) and Centaurea. These we sow right in their permanent rows. They do not require any protection, and unless the weather is very unfavorable we always have a good stand.

About the first of May we prepare our seed beds and frames for such items as Aquilegia (note we list these in two classes) Heuchera, Campanulas, Geum, Lobelia, Lavendula, Platycodon, Primula, etc. We build frames so that the young seedlings can be protected with cloth covers from the hot sun.

Prepare all seed beds, either frames or outside, by thoroughly plowing or spading, and raking, then for fine seeds level the soil and firm it lightly, scatter the seeds thinly, first seeing that the planting space is level, so that the seeds will not wash to one corner of the little block when watering. Then screen soil over the seeds to the depth of the size of the seeds, or so that they are just covered from sight. The really fine seeds, Heuchera, Lobelia, Leontopodium, Erinus, Androsace, Giant Petunia, all fine seed, do not have to be covered at all. Water lightly with a fine sprinkler and await results. Do not allow the soil to bake.

After the seedlings come up it is merely a matter of watching the weather. Do not allow them to become too moist, and do not permit the sun to hit them. Gradually give them a little air until they become large enough to take care of themselves. Many of these items we hold in the frames until the following spring when we line them out.

Each succeeding year we are sending out more and more perennial seeds for late summer and early Fall sowing. These seeds are sown in frames where they can be protected during the winter. Fine results are being obtained in this way, for it permits you to transplant the seedlings early in the Spring.

There are certain seeds which have given more trouble than others, and these are the ones which are better sown in the fall. It is not generally known that a few perennial seeds will do much better if sown late in the fall. These seeds are Adonis, Aetheoppapus, Anthericum, Apocynum, Asperula, Cassia, Colchicum.
Convallaria, Cirsium, Dicentra, Dictamnus, Ferula, Echinops, Gunnera, Hedysarium, Helleborus, Heracleum, Hypericum, Liatris, Morina, Oenothera (Missouriensis), Pardanthus, Peony, Phlox, Sidalcea, Spirea, Trollius and about all vine and shrub seeds. Above items, if planted in frames in fall or if planted outside, and given some light covering to prevent heaving, will prove satisfactory.

The seeds of some plants will lie dormant after sowing for quite some time. Some of the more stubborn, such as Eremurus, often lie for two years before showing. We recommend that flats or pots containing such items as the fine Alpines, Androsace, Primula, Saxifragas, and the like, be held for two years after date of sowing. Frost helps germination even after seeds have lain in soil for months. Note that SOME ITEMS MUST BE SOWN IN FALL for best results.

\section{Several Important Factors About Fine Seeds}

Be very careful that you do not sow seeds too deep. A fine rule to follow-sow all seed the depth of the size of the seed.

Be sure your seed frames are well drained. Many young seedlings are destroyed by excessive moisture. Be careful in watering the seeds. Too much force will wash them all to one corner of the bed.

The proper soil for a large majority of seeds is clean rich loam. Too much fertilizer is injurious. Do not permit the soil to become crusted. Seedlings cannot struggle through hard soil.

If the seeds do not germinate quickly, do not get discouraged for many items require a considerable length of time to germinate.

THIS IS IMPORTANT-We are ready at all times to be of assistance to you. We have been experimenting with seeds for over a quarter of a century. Possibly we have just the information you require. Do not hesitate to write. We consider it a pleasure to aid those who are interested in flowers. 


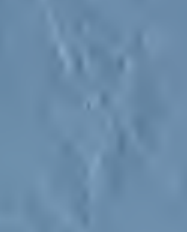

$$
\text { (1) }
$$

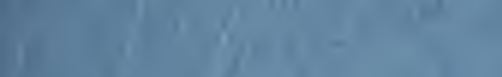

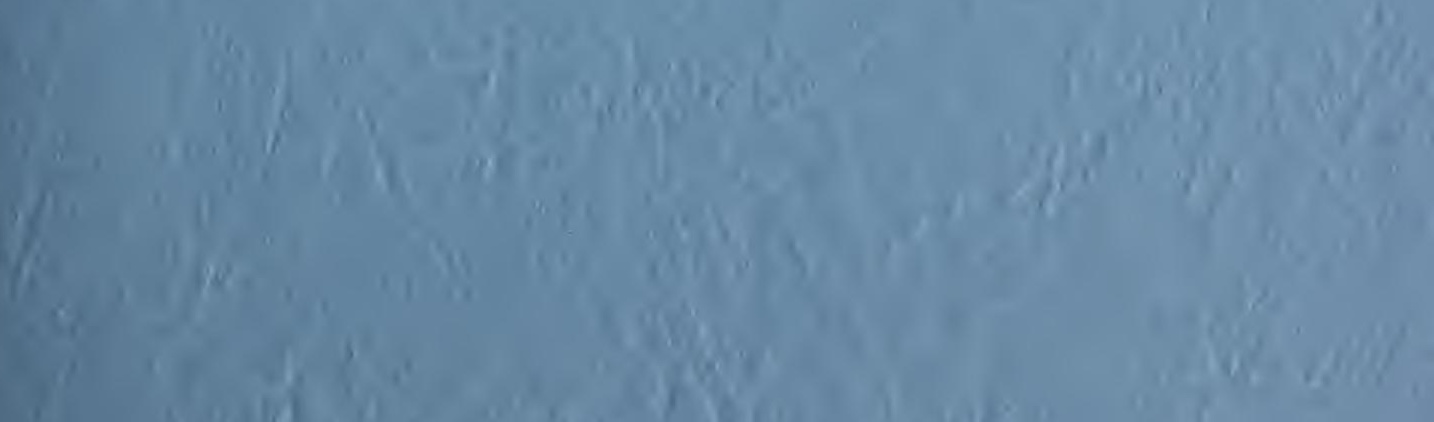

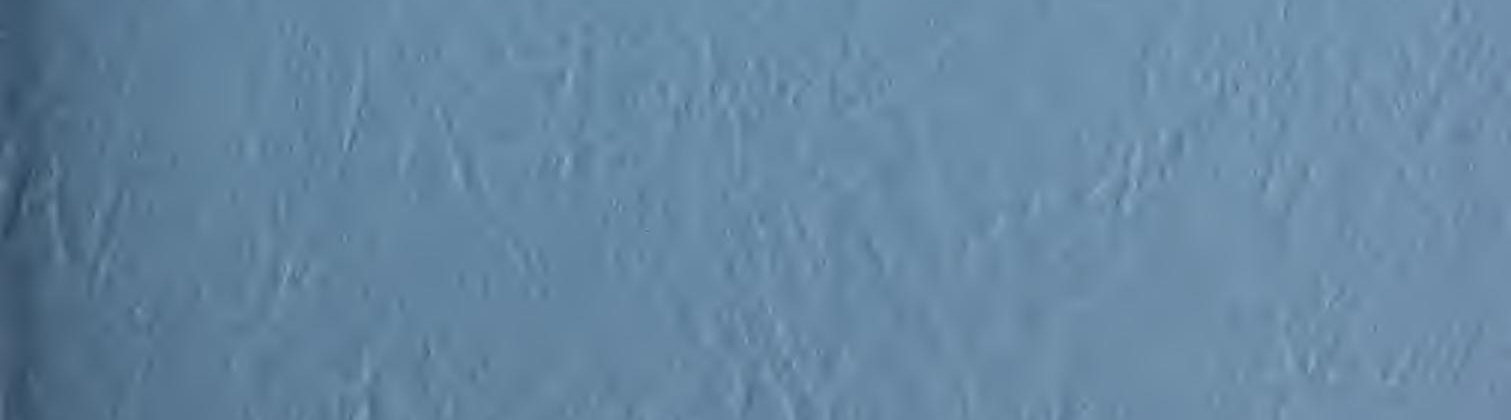

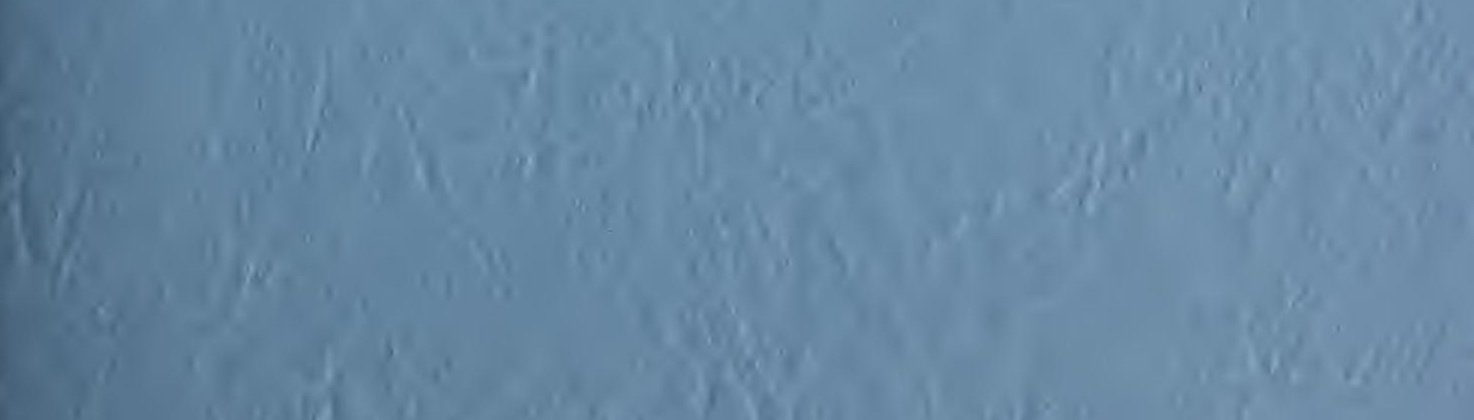

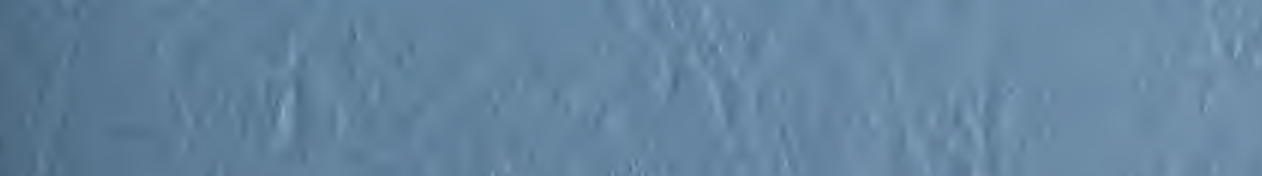

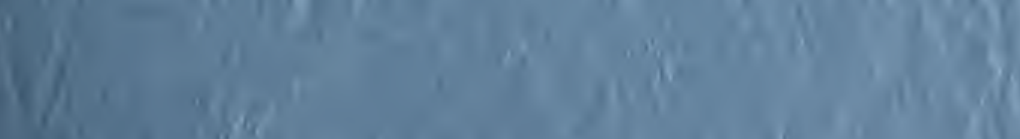

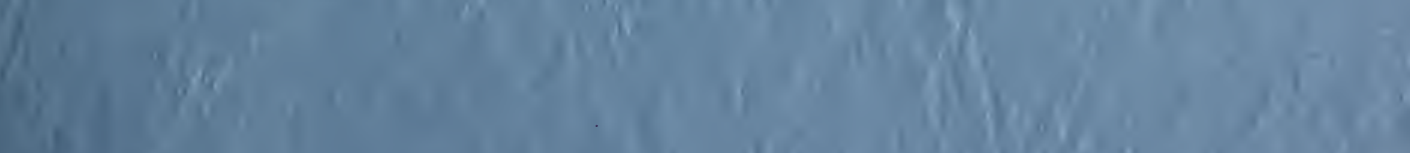

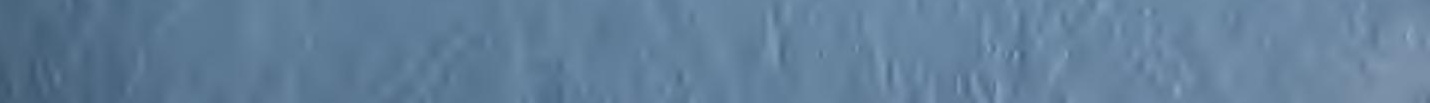


